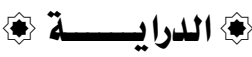

\title{
سلطة ولي الأمر في تقتيبد الحريات السياسية للمصلحة العامة
}

\author{
الدكتــــور
}

\section{محمد حلمي إبراهيه الحفناوي}

مورسر الفقه بكلية الشريهة والقانوف بهلهـا جامهة الأزهر 
$(7 \cdot 1)$

سلطة ولي الأمر في تقييد الحريات السياسية للصلحة العامة 
سلطة ولي الأمر في تقيبا الحريات السياسية للمصلحة العامة محمد حلمي إبر اهيم الحفناوي مدرس الفقه بكلية الثريعة والقانون بطنطا، جامعة الأزهر ، مصر الفيرو البريد الإليكتروني : MohamadALHefnawy452.el@azhar.edu.eg هلفص البحث : إن لولي الأمر مكانة عظيمة في الشريعة الإسـلامية، إذبه تقام أحكام الشريعة، وتساس العباد والبلاد، وتصرفه في الرعية منوط بالمصلحة، كتصرف ولي أمر المر في اليتيم في ماله، فعليه مراعاة ذلك في قيامه بإدارة شسئون العباد والبلاد، وعلى الأمسة طاعته في ذلك.

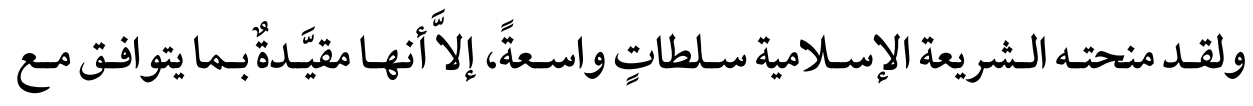
مبادئهـا وأحكامها، فلـه إدارة شـؤون البـلاد، وتــدير أمسور العبـاد، وإقامـة العـدل

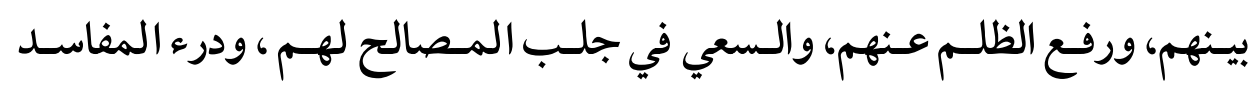
عنهم. وقد تناول البحث سلطة ولي الأمر في تقييد المبـاح، وسلطته في تقييد الحريات السياسية، ومنها ( التجنس، والمشاركة السياسية، والتعبير عـن الرأي) باعتبارهـا مـن جملـة المباحـات ؛ وذلك للمـصلحة العامـة. وأثبـت أن مـن حـق وليّ الأمـر تقييد المباح بـالقيودوالضوابط الشرعية ، بعيدًا عن الهوى والتعسف و التحيّز والمحاباة.

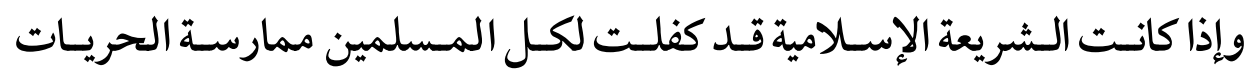

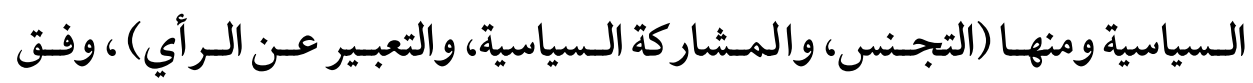


(71)

سلطة ولي الأمر في تقييل العريات السياسية للصصلحة العامة

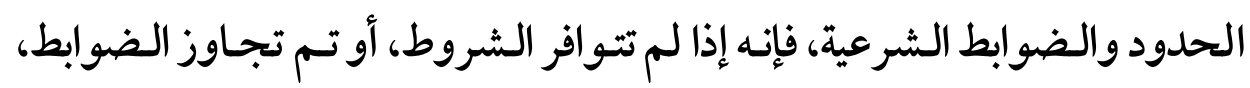

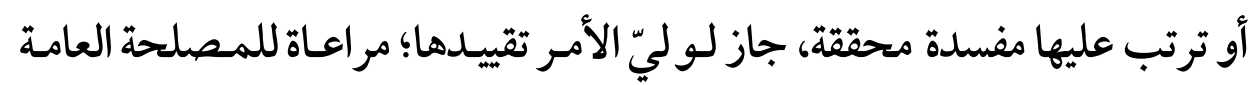
للمسلمين؛ لأن تصرفه في الرعية منوط بالمصلحة.

وعليه فإن لولي الأمر سلطة تقييد الحريات السياسية مر اعاة للمصلحة العامة.

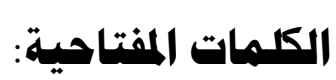

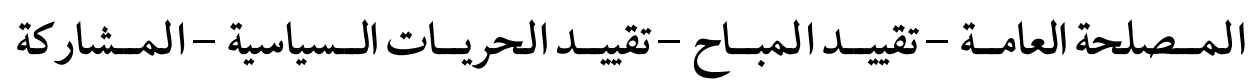
السياسية - التعبير عن الرأي. 


\section{The power of the Ruler to restrict political freedoms according to public interest}

Muhammad Helmy Ibrahem Al-Hefnawy

Lecturer of jurisprudence, Faculty of Sharia and Law in

Tanta, Al-Azhar University, Egypt.

Email: MohamadALHefnawy452.el@azhar.edu.eg

\section{Abstract:}

The ruler has a great status in the sight of Islamic Jurisprudence, as by whom the rulings of the Shari'a are established, and the people and the country are governed, as his behavior towards subjects is formed according the general interest, such as the conduct of the guardian regarding the orphan's money, so the ruler must consider such interest during his management of the affairs of subjects, the country and the nation should obey him in that.

Islamic law has granted him wide powers, but they are restricted in accordance with its principles and rulings. He can manage the affairs of the country, manage matters of people, prevail justice among them, remove injustice from them, seek to bring interests to them, and remove the evil from their way.

This research dealt with the authority of the guardian in restricting the permissible, and political freedoms, including (granting nationality, political participation, and expression of opinion ) as part of permissible. It proved that the guardian has the right to restrict the permissible by religious restrictions and rules, away from passion, arbitrariness, prejudice and favoritism

If Islamic law has guaranteed to all Muslims the exercise of political freedoms, including granting nationality, political 
$(7 \mid r)$

سلطة ولي الأمر في تقييل الحريات السياسية للمصلحة العامة

participation, and expression of opinion in accordance with Islamic Shari'a limits and rules, if such conditions are not fulfilled, the rules become beyond limit, or lead to any corruption, the guardian may then restrict them; Taking into account the general interest of all Muslims;

the ruler has the power to restrict political freedoms according the public interest.

\section{keywords:}

Public interest - Restriction of permissibility - Restriction of political freedoms- Political participation- Expression of opinion. 


\section{بسم الله الرحمن الرحيم}

\section{المقدهة}

الحمد لله رب العالمين ، والصلاة والسلام الأتمـان الأكمـلان على سـيدنا

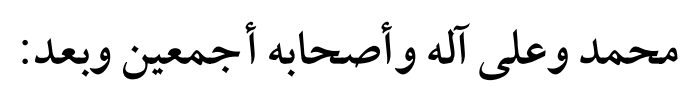

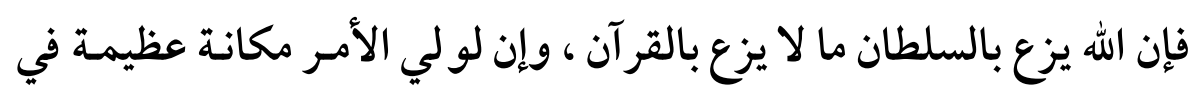

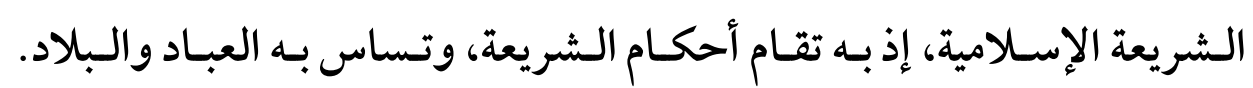
فتصرفه في الرعية منوط بالمصلحة، كتصرف ولي أمر اليتيم في ماله، فعليه مر اعاة ذلك في قيامه بإدارة شئون العباد والبلاد، وعلى الأمة طاعته في ذلك.

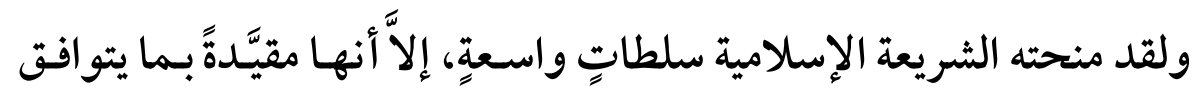

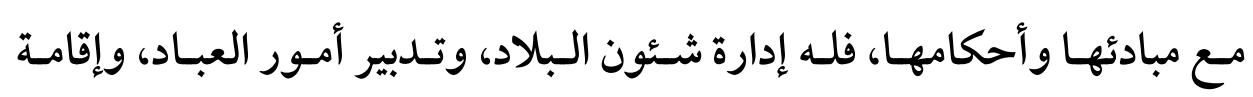

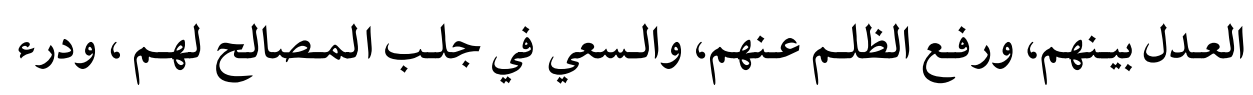

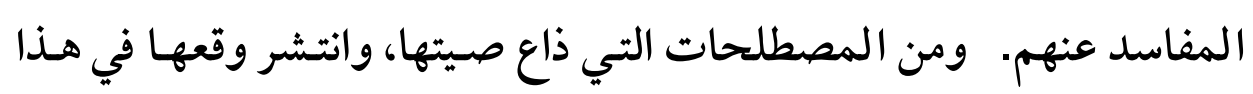

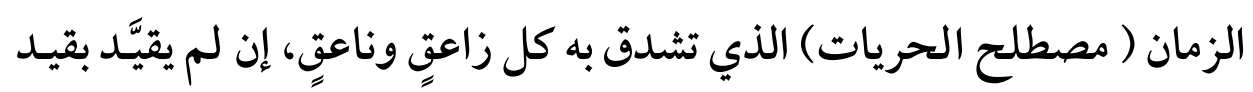
الشرع عاش الناس في فوضى لا نجاة منها إلا بـالعودة إلى الشريعة الإسلامية وأحكامها.

لذا فإن الشريعة الغـراء قـد منحـت ولي الأمـر سـلطة تقييد المبـاح، وهـذه

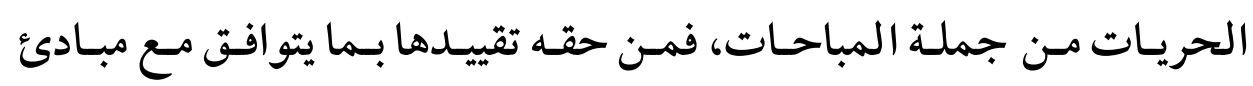

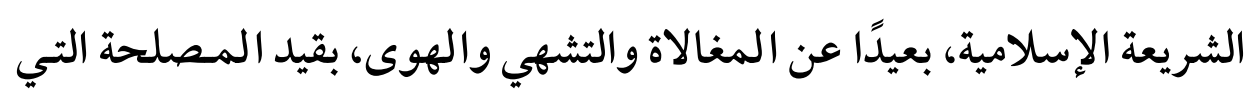

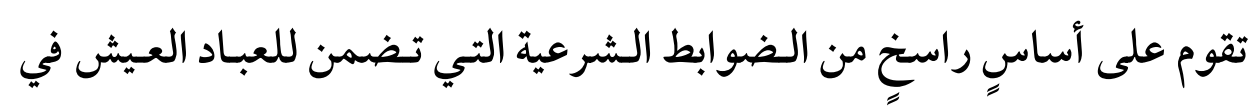

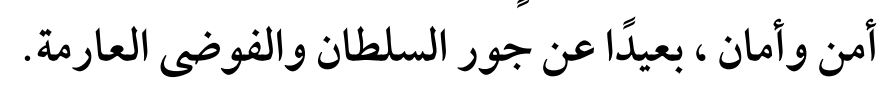


(7)\&)

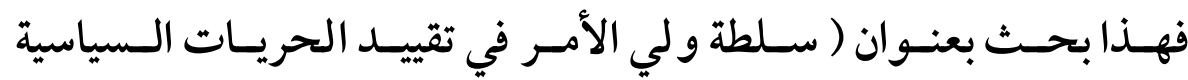

للمصصلحة العامـة ) فـاله أسـأل أن يـوفقني فيسه، ويهـديني إلى مـا فيـه رضـاه،

$$
\text { ويرزقني التوفيق والإخلاص . }
$$

$$
\text { إشكالية البحث : حاولت الإجابة على عدة تساؤلات ، هي: الإصئ }
$$

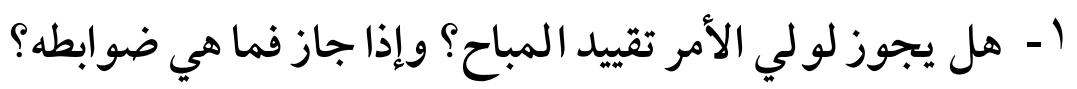

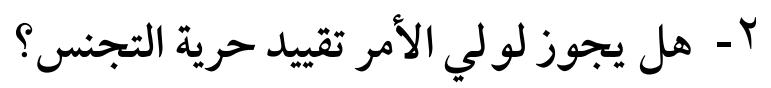

؟- هل يجوز لولي الأمر تقييد حرية المشاركة السياسية؟

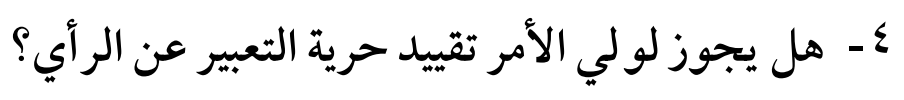

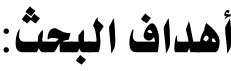

1 - محاولة الوقوف على اهتمام الشريعة الإسلامية بـوليّ الأمر وسلطاته

التي يسوس بها العباد والبلاد ويحقق بها المصلحة العامة .

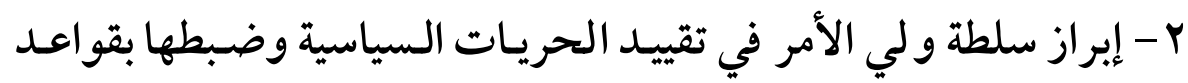

وضوابط الشريعة الإسلامية ، التي تحقق المصلحة العامة .

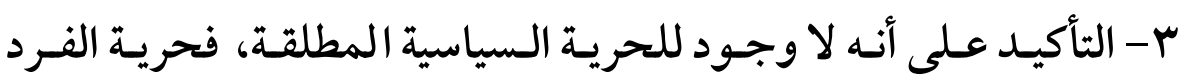

تنتهي عند حرية غيره، وإن لم تقيد الحريات السياسية بقيد الشرع انفلت عقدـ

الأمة ، وعمت الفوضى واستشرى الفساد.

منهج البحث :

اتبعت في البحث المناهج التالية : 
(710)

أولًا: المنهج الاستقرائي : الذي يقوم على استقر اء آراء الفقهاء في سلطة

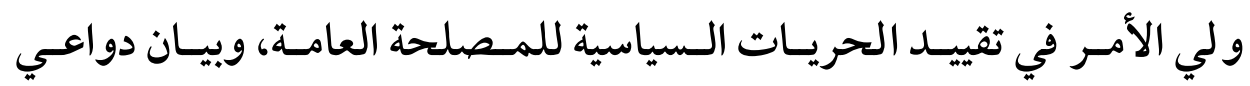
الحاجة إلى هذا التقييد.

ثانيًا: المنهج الاستنباطي: الذي يقوم على استنباط أوجه الدلالة من أدلتها التفصيلية ؛ للاستدلال بها على المسائل محل البحث .

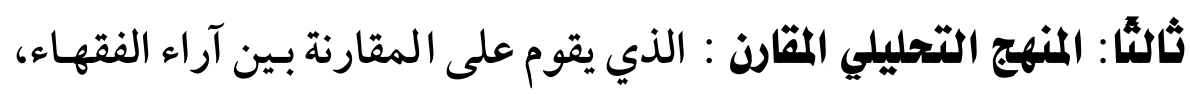
وعرض أدلتهم، ومناقشتها، والترجيح بينها .

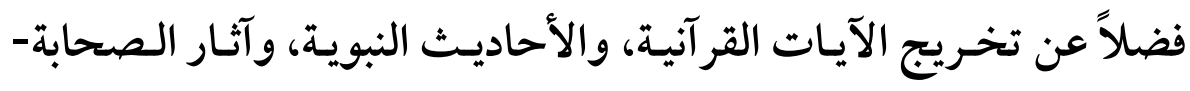

$$
\text { خطي الله عليهم-. }
$$

يشتمل البحث على مقدمةٍ و تمهيدٍ وفصلين وخاتمةٍ .

أما المقدمة ففي أهمية البحث ودواعيه .

$$
\text { وأما التمهيل ففي بيان مفردات العنوان. }
$$

وأما الفصل الأول ففي سلطة ولي الأمـر في تقييد المبـاح، ويشتمل على معلى

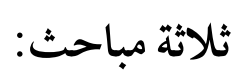

المبحث الأول : حقيقة تقييد المباح.

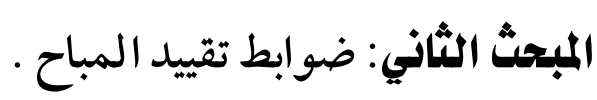

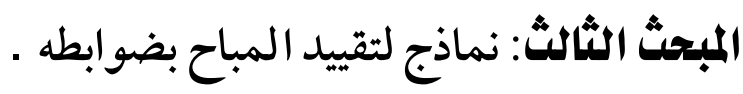

وأما الفصل الثاني فني تقييد الحريـات السياسية، ويشتمل على ثلاثة 
(7)7)

سلطة ولي الأمر في تقييل الحريات السياسية للصصلحة العامة

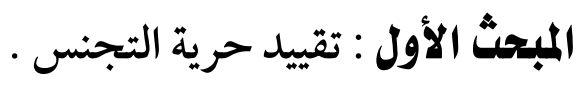

المبحث الثاني: تقييد حرية المشار كة السياسية.

المبحث الثالث: تقييد حرية التعبير عن الرأي .

وأما الخاتقة فني أهم النتائج والتوصيات .

فالله أسأل أن يعينني على عملي هذا ، وأن يجعله خالصا لوجهه الكريم ،

إنه ولي ذلك و القادر عليه .

د محمد حلمي إبراهيي الحفناوي 


\section{التمهيد}

قبل البدء في موضوع البحث لابد من معرفة مفردات العنوان وهي :

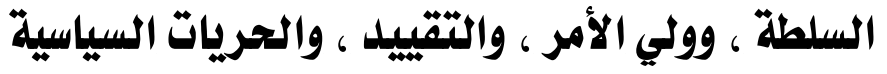

السلطة :

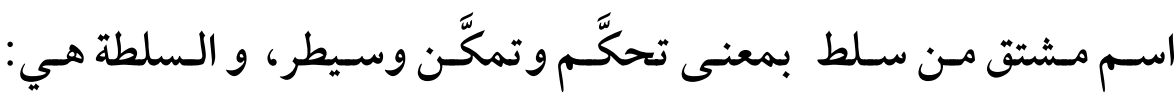

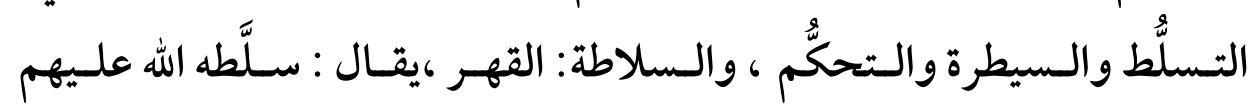

تسليطا فتسلَّط عليهم ، والسُّلطان الوالي ( ')

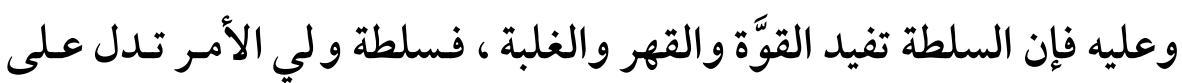

مدى تمكنه وقدرته على إلزام الناس بأوامره وتنفيذ أحكامه.

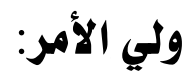

\section{مركب إضافي من كلمتين هما: ( وليّي، وأمر )}

فالو لي هو: الناصِرُ، قال ابن الأَثَير : وكأَن الوِلايـة تُشُعر بالتَّدْبير والقُدرة

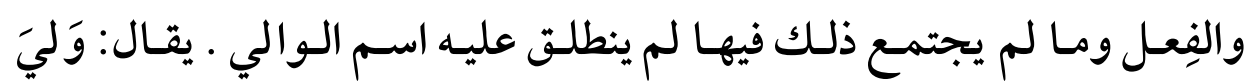

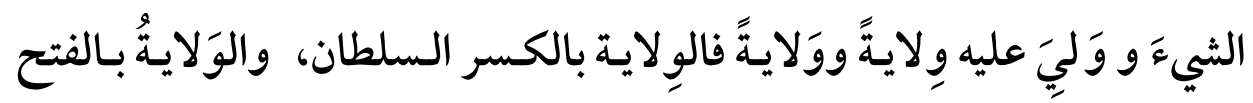

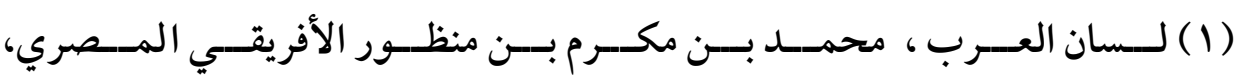

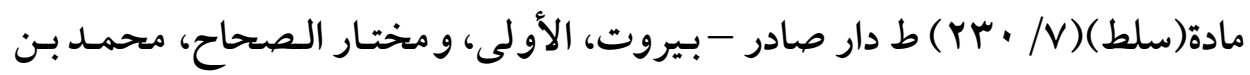

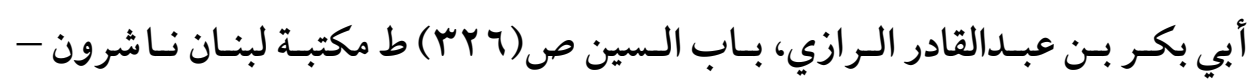


(7)A)

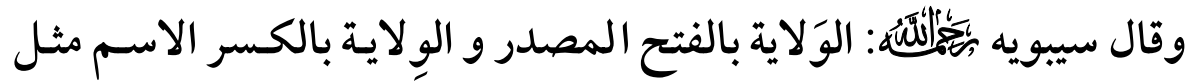

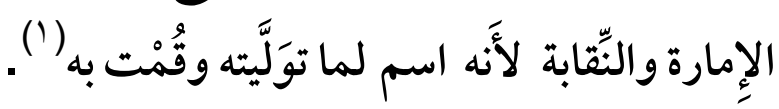

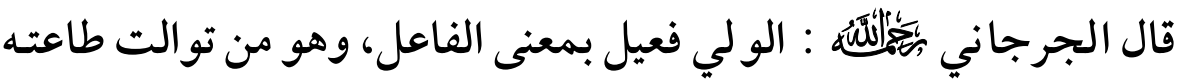

من غير أن يتخللها عصيان (؟).

ومنه وليّ أمر اليتيم الذذي يقوم بكفالته ورعايته، وعليه فـالولي هـو : مـن

ولي أمرًا أو قام به ، ولهذا أطلق عيه وليّ الأمر.

\section{والأمر : يطلق في اللفة على معنيين هما :}

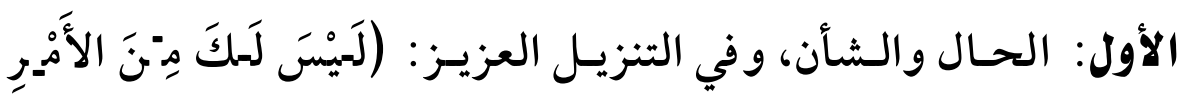

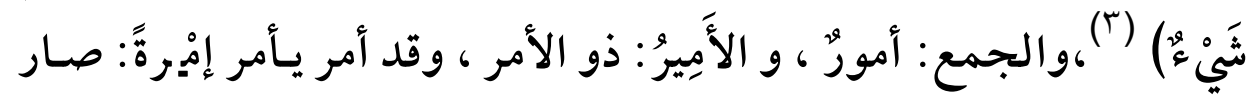

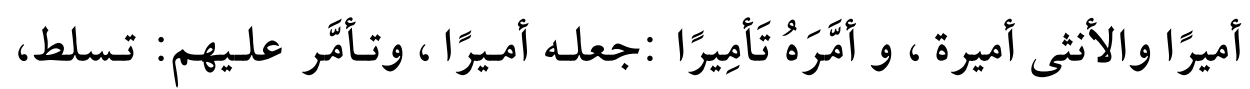

وأولو الأمر: الرؤساء والعلماء (๕).

$$
\text { ( ) لسان العرب ، مادة(ولي)(10/ ه • ع ). }
$$

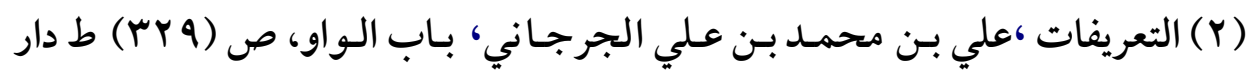

$$
\begin{aligned}
& \text { الكتاب العربي -بيروت، الأولى ، ه •ـ أهـ، تحقيق : إبراهيم الإبياري. }
\end{aligned}
$$

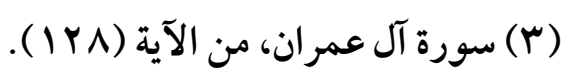

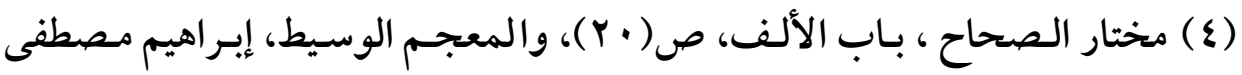

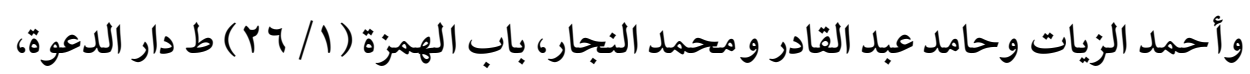
تحقيق مجمع اللغة العربية. 
(719)

والثاني: ضد النهي ، وهو: طلب الفعـل ، والجمـع: أوامـر ؛ للتفريـق

بينهما (')

وعليه : فإن الأمر في اللغة يفيد معني الحال والشأن والطلب مما يتضمن

$$
\text { معنى السلطة والإمارة. }
$$

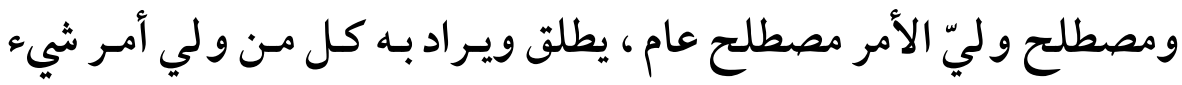

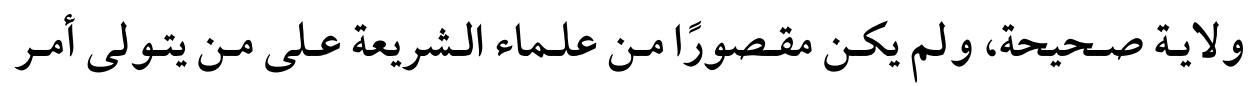

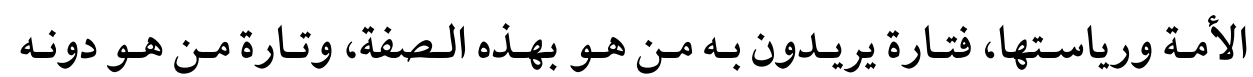

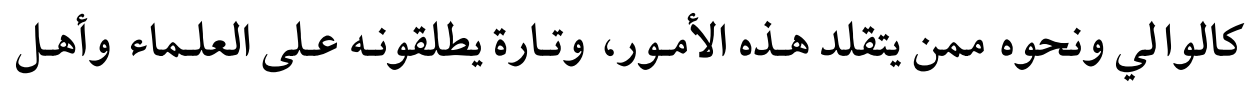

فيتضح مما سبق أن ولي الأمر هو : من منحه الشرع سلطات تخوله القيام

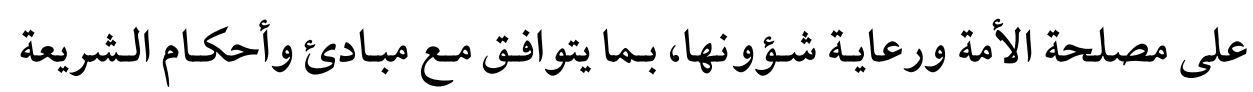
الإسلامية .

\section{التقبيل : الإنهيه}

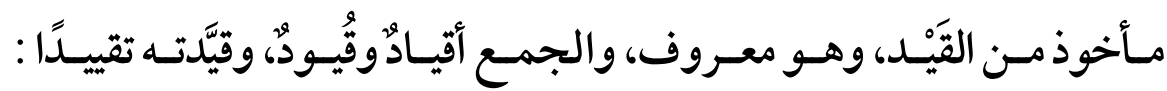

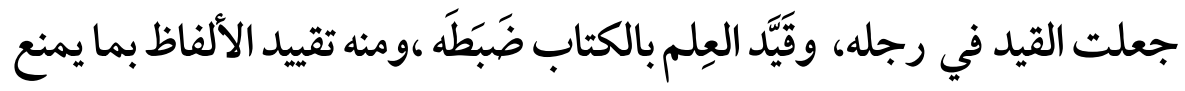

(1) تاج العروس لمحمّد بن محمّد بن عبد الرزّاق الحسيني (الزَّبدي) فصل الهمزة مع

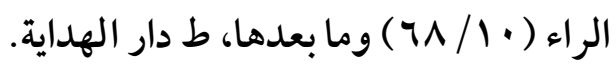

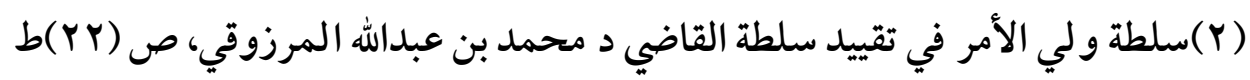

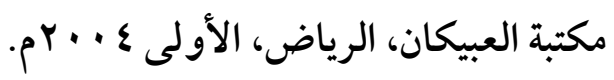


$(7 r \cdot)$

سلطة ولي الأمر في تقييل العريات السياسية للصصلحة العاهة

الاختلاط ويزيل الالتباس (')

والمر اد بالتقييد هنـا: الضبط أو المنـع مـن التصرف مـن قِبَّل وليِّ الأمر

كلما دعت الحاجة، أو اقتضت المصلحة.

الحريات السياسية :

مركب إضافي من كلمتيز هما: (الحرية، والسياسة)

أولاً: تعريف الحرية:

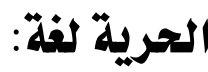

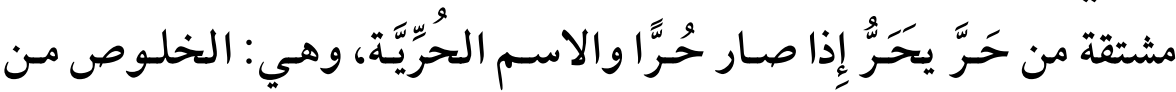

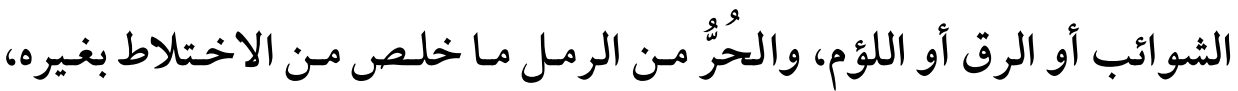

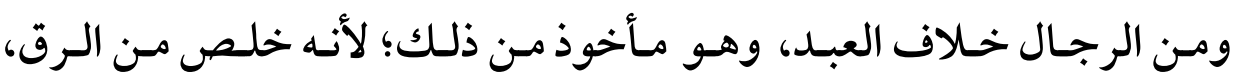

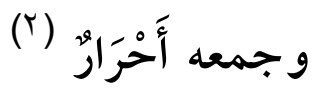

واصطاحًا:

هي المكنـة العامـة التي يقر رهـا الشارع للأفر اد، بحيـث تجعلهـم قـادرين

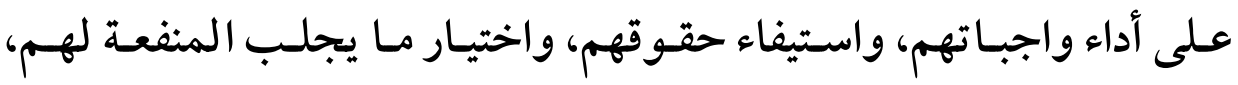

ويدر أ المفسدة عنهم، دون إلحاق الضرر بالآخرين (َ).

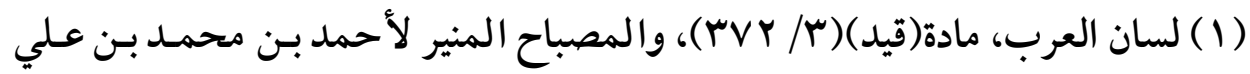

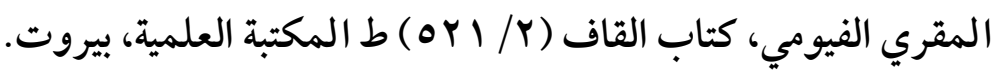

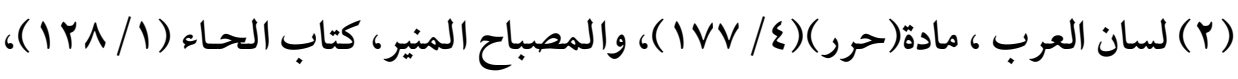

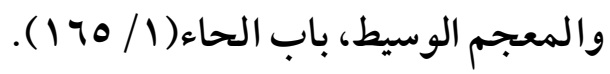

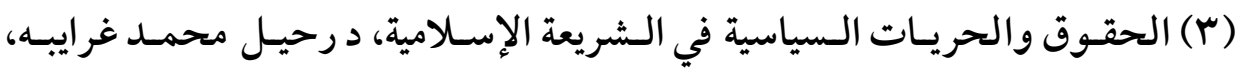

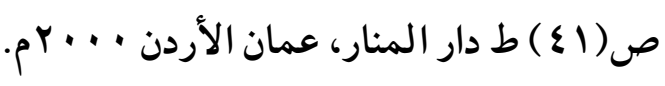


(TrI)

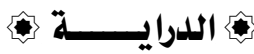

\section{ثانيًا: تعريف السياسة:}

السياسة لفة:

مـصدر سـاس الأمـر سياسـةً، وهـي: القيـام عـلى الـشيء بـما يُصلحه،

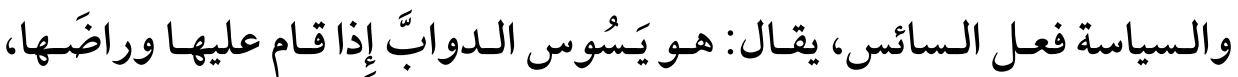

والوالي يَسُوسُ رَعِيََّّهَ (').

واصطلاحًا:

المتأمـل في كتـب الفقـهـ يـرى أن الفقهـاء عـبرواعـن السـياسة بالأحكــام

السلطانية أو السياسة الشرعية، وهي عند المتقدمين: فعل شيءٍ مـن الحـاكم

لمصلحةٍ ير اها، وإن لم يرد بذلك الفعل دليلّ جزئيه (؟).

وعند المعاصرين:

الأحكام التي تنظم بها مرافق الدولة، وتدبر بها شؤون الأمة، مع مراعـاة أن

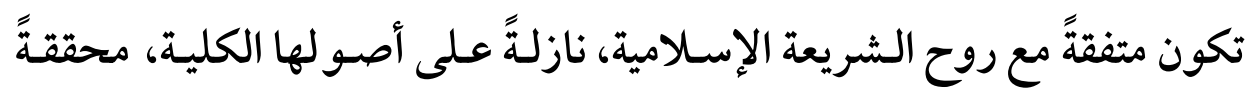

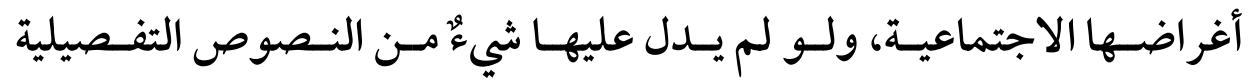

الجزئية الواردة في الكتاب والسنة(َّ).

(1) لسان العرب ، مادة(سوس)(T/ / I ).

(Y) البحر الر ائق شرح كنز الدقائق لزين الـدين ابـن نجيم الحنفي (1) / 11 ) ط دار المعرفة، بيروت.

(r) الجريمة السياسية في الشريعة الإسلامية والقانون، منذر عرفات زيتون، ص(10) ط دار مجدلاوي، عمان الأردن ب. - بrم. 
(TrY)

أو هـي : تــدير الـشؤون العامـة للدولـة الإسـلامية بــما يكفـل تحقيـق المصالح، ودفع المضارّ، ممـا لا يتعـدى حـدود الشريعة وأصسولها الكلية،

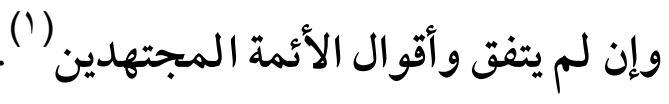
والحريات السياسية جزءٌ أصيلٌ من صميم هذا الدين، و ليست منحةًّ مـن أحسـدِ، إذ أنهـا تقـوم عـلى أســاس أن الأمسة هـي صـاحبة الـسيادة في شـؤون الحكـم ، مـن حيـث اختيـار الحـاكم ومر اقبتهـ و عزله ، ولقـد كفلها الإسـلام بكل معانيها، بـل وحـث عليها ولاة الأمـر، ودعـاهم إلى ممارستها ممارسةً جادةً في واقع الحياة السياسية. وعليه فإن الحريات السياسية هي : أن يكسون الشعب هـو صـاحب الكلمـة العليا في شؤون الحكمم ، ويتم ذلك بالمشاركة في مسؤولية الحكـم، سواء بطريقة مباشرة، أو غير مباشرة، عن طريـق ممثليـه، ويتمثل ذلك في اختيار الحـاكم، وفي مراقبته، و محاسببته عـلى أعماله، و في مشار كته في الحكـم، وفي عزله إذا حاد عن الطريـق القويم، أو إذا جـاء مـا خـالف مـا فرضـته الأمـة عليه (r)

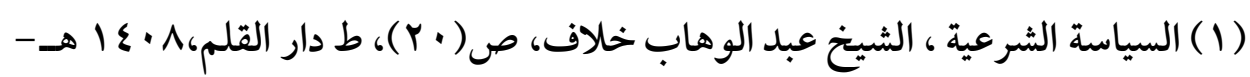
$\cdot p^{1911}$

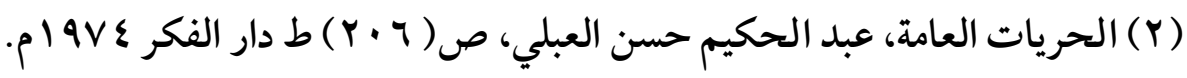




\section{المصلحة العامة:}

مركب إضافي من كلمتين هما: (المصلحة، والعامة)

\section{تصريف المصلحة:}

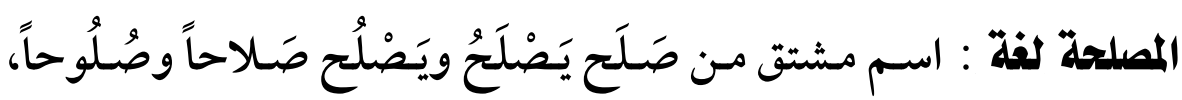

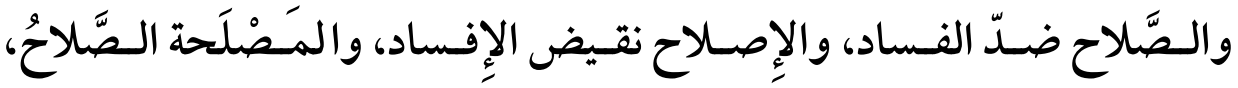

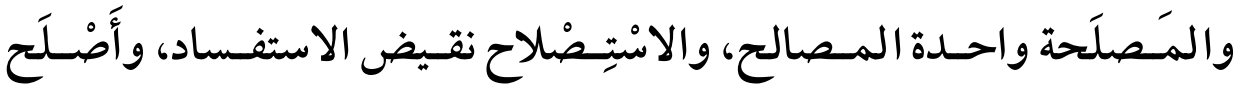

الثيعَ بعد فساده أَقامه ('). واصطاحًا:

المحافظة على مقصود الثرع، ومقصود الشرع من الخلقق خمسة، وهـو:

أن يحفـظ علـيهم ديــهم، ونفــهم، وعقلهـم، ونسـلهم، ومـالهم، فكـل مـا

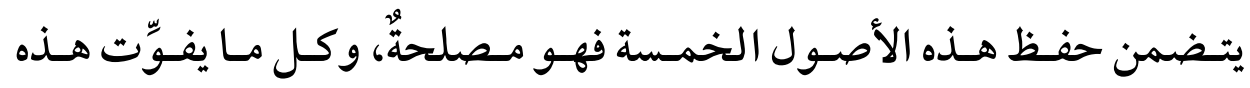

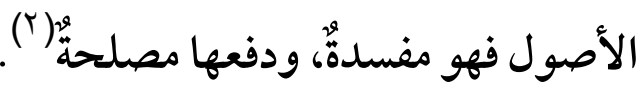

\section{تعريف العامة:}

اسم مشتق من عَمَمَ يفيد التمام والشمول، والعامّةُ خلاف الخاصَّة، يقـال:

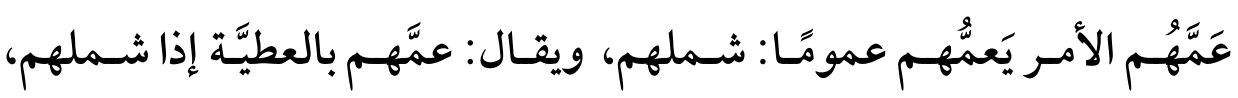

$$
\text { (1) لسان العرب، مادة: صلح (Y/ T 1 10 ). }
$$

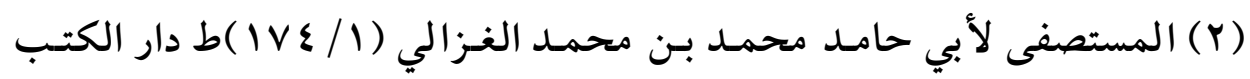

العلمية - بيروت، الأولى ، ساء أهـ ، تحقيق: محمد عبد السلام عبد الشافي. 
( $\operatorname{r\varepsilon } \varepsilon)$

سلطة ولي الأمر في تقييد الحريات السياسية للمصلحة العامة والعامَّة اسم للجمع ( ').ومنه العام: وهو اللفظ المستغرق لجميـع مـا يصلح

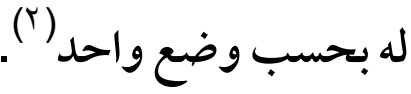
والمصلحة العامة: هي ما فيـه صـالحُ عمـوم الأمـة أو الجمهـور، ولا التفـاتَ منـه( ولي الأمـر) إلى أحوال الأفر اد إلّا مـن حيـث إنهـم أجـز اء مـن مجمـوع الأمـة، مثـل حفـظ المتمـوّلات مـن الإحــراق والإغـر اق؛ فــإن في بقــاء تلـك المتمـوّلات منــافع ومصالح، هي بحيث يستطيع كل من يتمكّن مسن الانتفـاع بهـا نوالها بـالوجوه

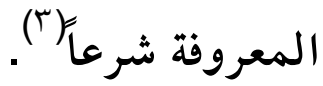

وهذا تقسيم للمصالح باعتبار تعلقها بعموم الأمة أو جماعتها أو أفرادهـا، فتنقسم بهذا الاعتبار إلى كليَّة وجزئَّةِّة، وير اد بالكليـة في اصطلاحهم مـا كـان عائدًا علمى عموم الأمة عودًا متماثلاً، وما كان عائـدًا عـلمى جماعـةٍ عظيمـة مـن

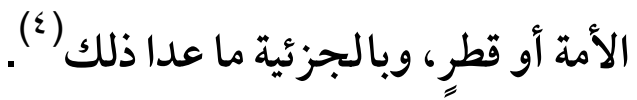

(1 ) لسان العرب، مادة: عمم (Y / / ع § ).

$$
\begin{aligned}
& \text { (Y) المحصول (Y/ (Y ) }
\end{aligned}
$$

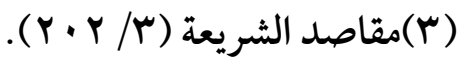

$$
\begin{aligned}
& \text { ( ) مقاصد الشريعة (r/ r r ) . }
\end{aligned}
$$




$$
\begin{aligned}
& \text { الفصل الأول } \\
& \text { سلطة ولي الأهمر في تقييد المباح } \\
& \text { ويشتمل على ثلاثة مباحث: } \\
& \text { المبحث الأول : حقيقة تقتييد المباح }
\end{aligned}
$$

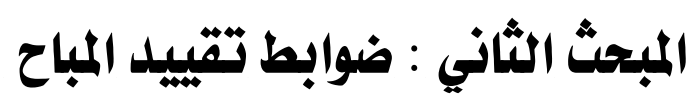

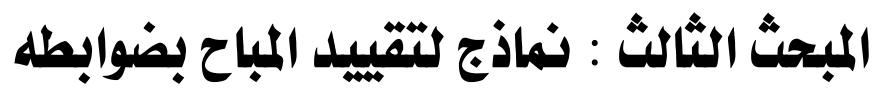




\section{المبحث الأول}

\section{هقيقة تقيسد البباح}

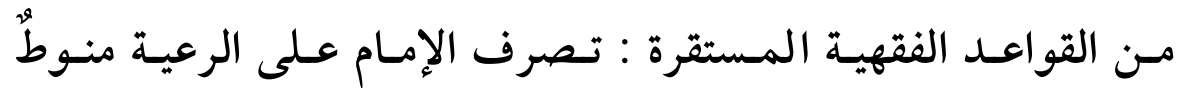

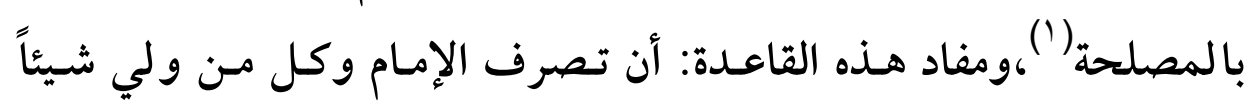
من أمور المسلمين؛ يجب أن يكون مقصوداً به المصلحة العامـة، أي بـما

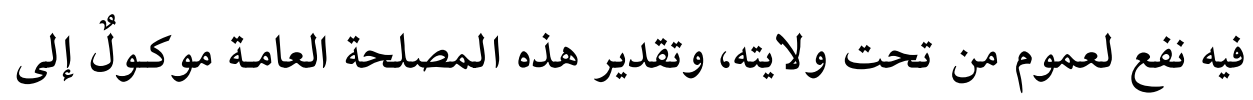
الإمام أو من ينيبه الإمام سواءٌ علمها عامة الناس أو خفيت عليهم ولهم.

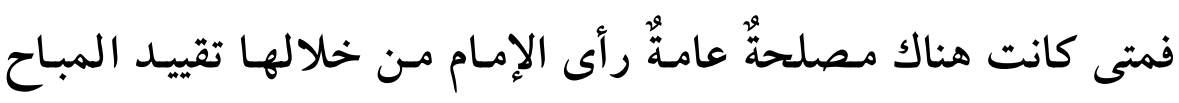
أو الإلزام به؛ فإنَّ تصرف الإمـام بناء على ذلى ذلك تصرفًا شرعيًا صسحيحًا

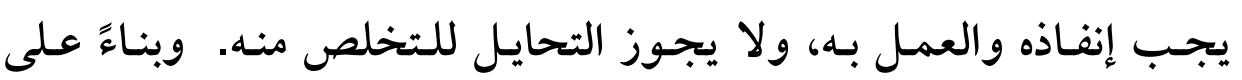
ذلك فإن ولي أمر المسلمين إذا رأى المصلحة في تقييد أو الإلزام بشيء من المباحات فله ذلك؛ بعد التحقق من وجـود المصلحة العامـة، وانتفاء

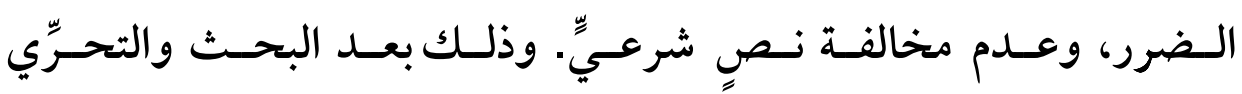

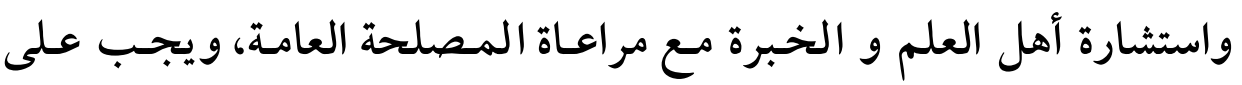

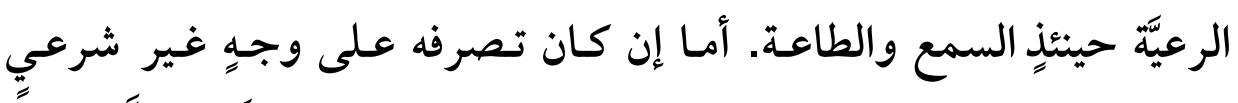

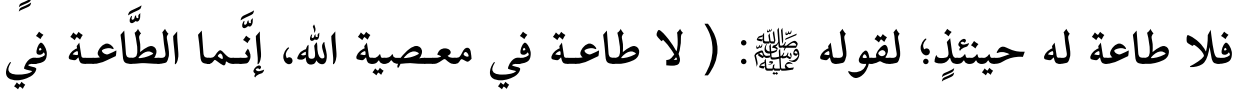

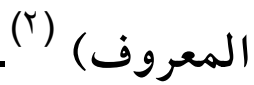

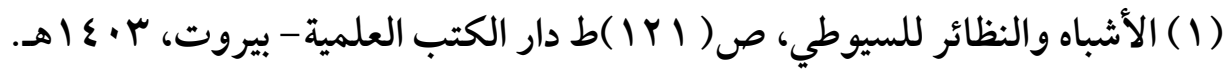

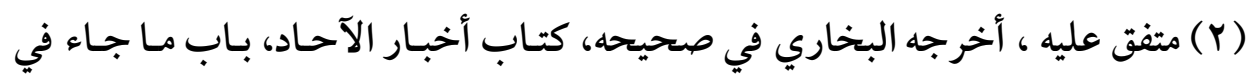




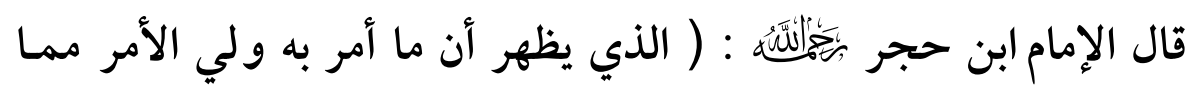

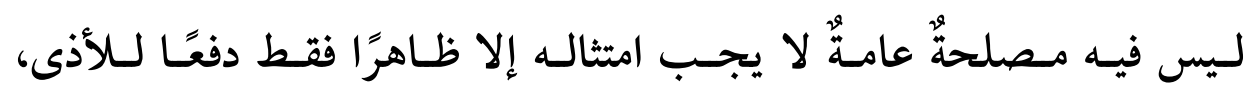

بخلاف ما فيه ذلك؛ يجب باطنًا أيضًا) ('). وقد استبط العلماء من هذه القاعـدة :أن للإمـام تقييد المباح ، وهـذه القاعدة وإن لم ينص عليها من ألَّف في القواعد والضوابط الفقهية، فهي من المعاني المستبطة التي تؤخذ من ضـابط المصلحة المنصوص عليه في تلك قاعدة .

\section{تعريف تقييد المباح:}

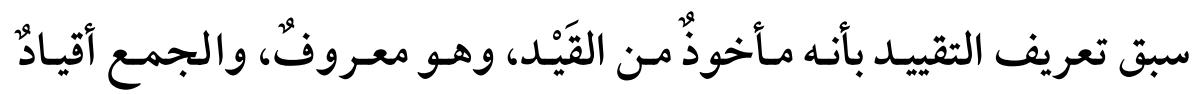

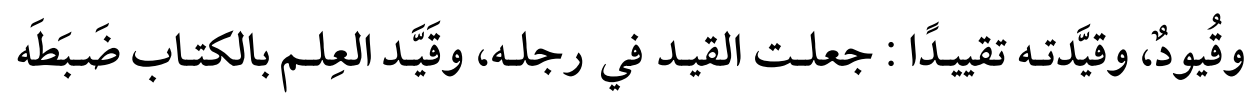
،ومنه تقييد الألفاظ بما يمنع الاختلاط ويزيل الالتباس . وتقرر أن المـراد بـه هنا: الضبط أو المنع من التصرف من قِبَل وليِّ الأمر كلما دعت الحاجـة، أو اقتضت المصلحة.

$$
\text { إجازة خبر الواحد الصدوق، رقم(VYOV)، }
$$
ومسلم في صحيحه، كتاب الإمارة، بـاب وجوب طاعة الأمراء في غير معصية، رقم

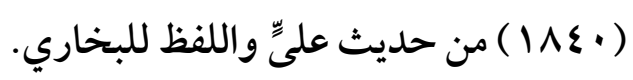

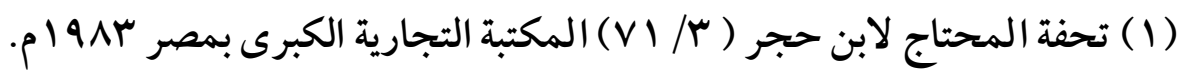




\section{تعريف المباح:}

\section{المباح لفة:}

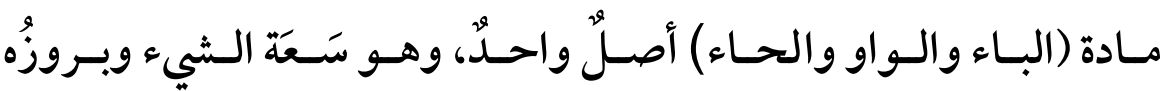

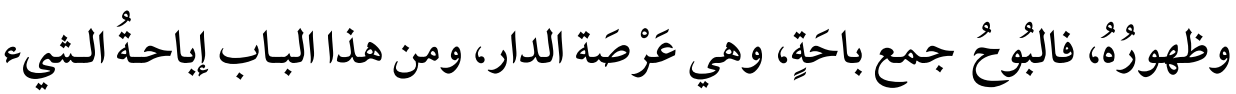

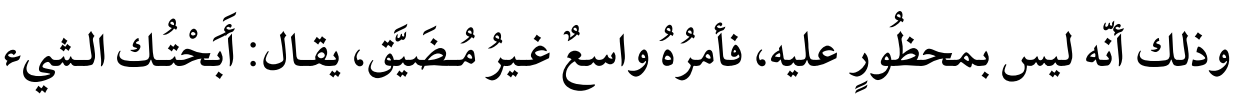

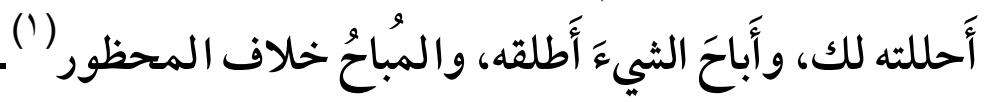

هو الذي أُعلم فاعله أو دل على أنه لاحرج عليه في الفعل والترك(؟). واصطالمًا:

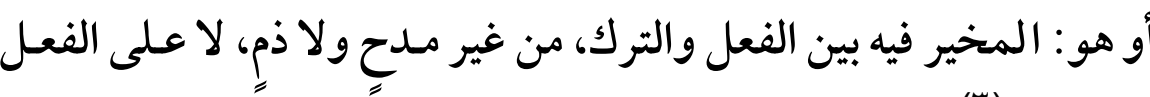
ولا على الترك (־). ويمكن القول بأن المباح هو: ما استوى فيه جانـب الفعـل والترك، فلا ثواب في فعله ولا عقاب على تركه.

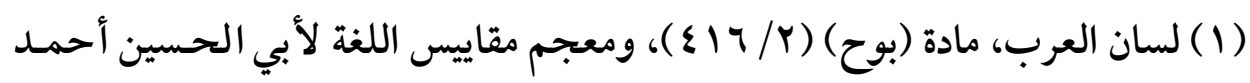

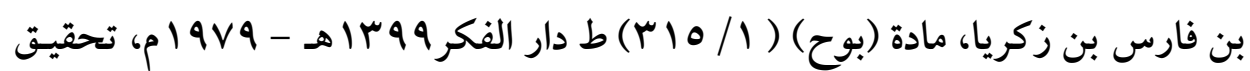

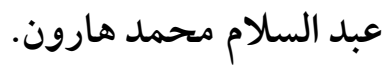

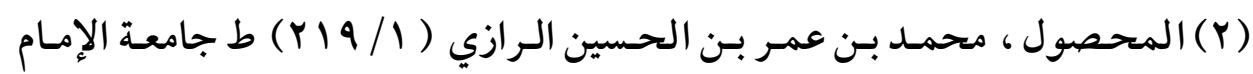
محمد بن سعود الإسلامية - الرياض ل . ع اهـ، تحقيق : طه جابر فياض العلواني.

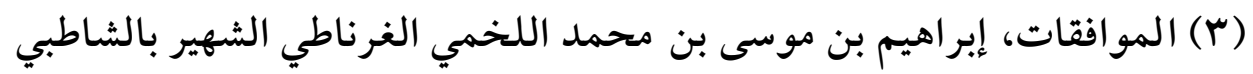

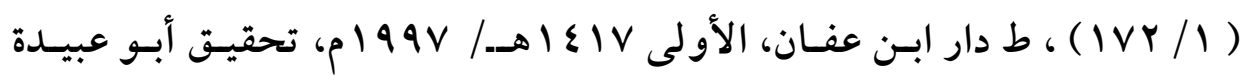
مشهور بن حسن آل سلمان. 
(7rq)

ويمكن القول بـأن تقييد المبـاح هـو: صرفه عـن الإباحـة إلى غيرهـا مـن

الأحكام الأخرى بإعمال القواعد الأصولية والفقهية.

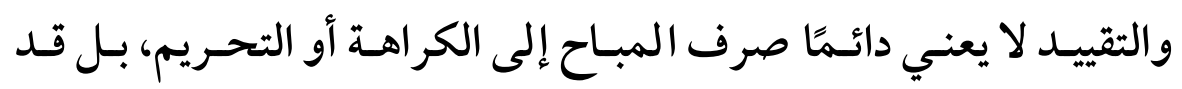

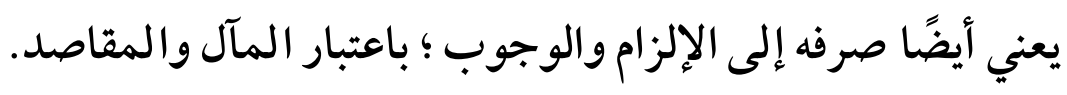

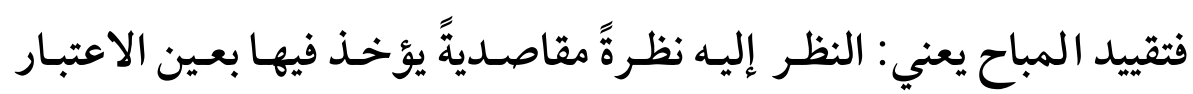
مـآلات الفعـل، والمـصالح المرجوة منه، أو المفاســ المترتبـة على الإقـدام

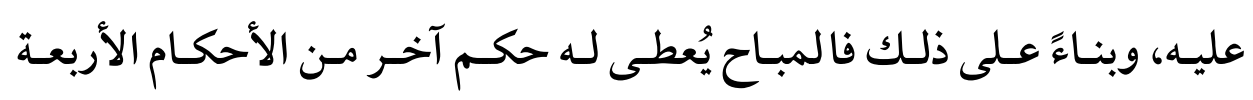
المتبقية: - 20 - n

ترجيح جانب الإذن المباح يصبح مندوبًا أو واجبًا.

ترجيح جانب الترك المباح يصبح مكروهًا أو حرامًا ( ').

والمباح نوعان :

فتارة تثبت إباحة الفعل بنصِ شرعيِّ، وتـارة تثبـت بالإباحة الأصلية، فبإذا

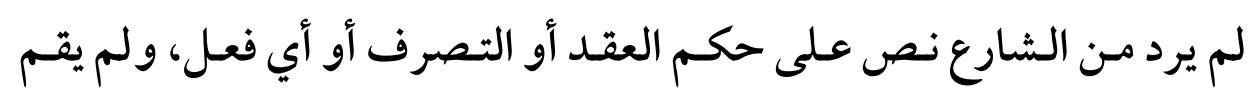

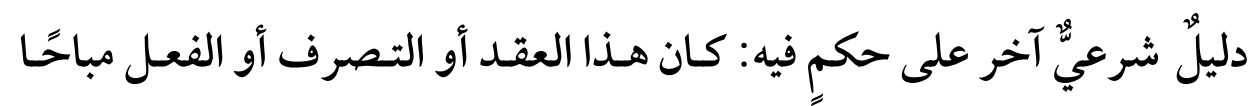
بالبراءة الأصلية؛ لأن الأصل في الأشياء الإباحة.

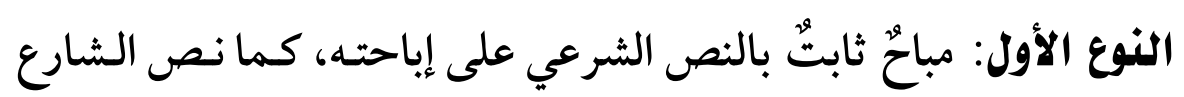
على أنـه لا إثـم في الفعـل، فيـدل بهـذا عـلى إباحتـه ، كقولـه تعـالى : ( فَإِنْ

(1) تقييد المبـاح، د الحسين المسوس، ص(Y9) مركز نماء للبحوث والدراسـات،

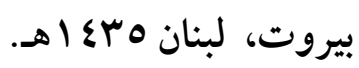


(7r.)

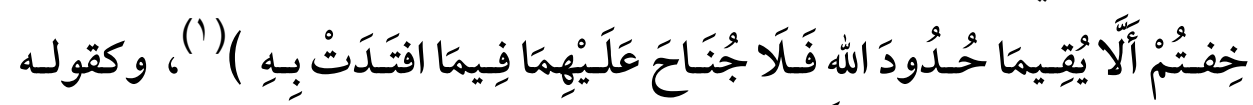

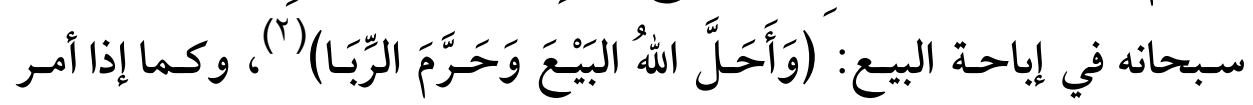

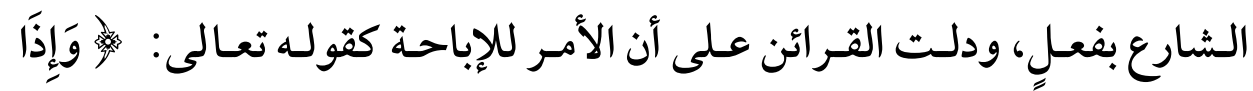

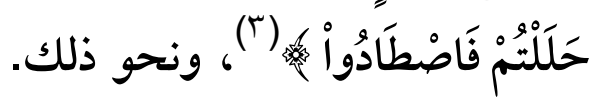
وهذا النوع لا يمكن تقييده أو الإلزام به ؛ لأن ذلك تغيير لشرع الله ؛لأن

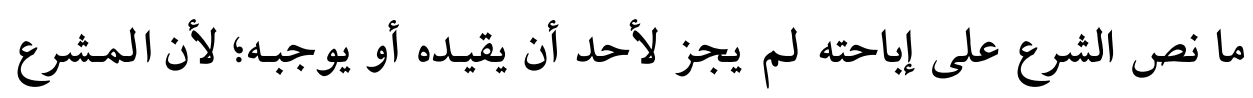
هو الله تعالى وحده.

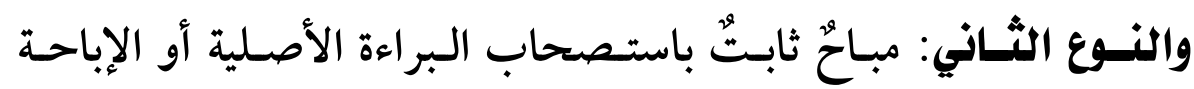

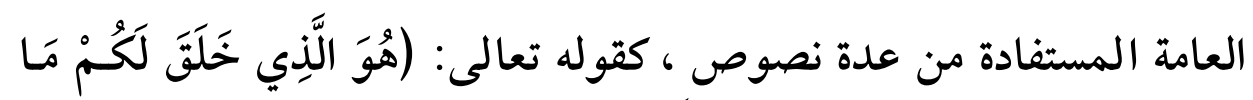

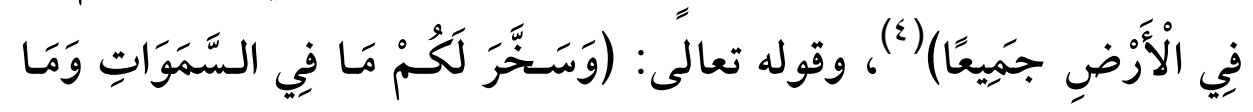

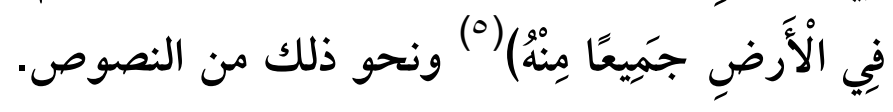

وهـذا النوع الأصـل فيـه الإباحـة، كالسكنى ، والتنقل مـن مكـان لآخـر، والركوب، والمشي وكل هذه الإباحات ثابتة باستصحاب البراءة الأصـلية،

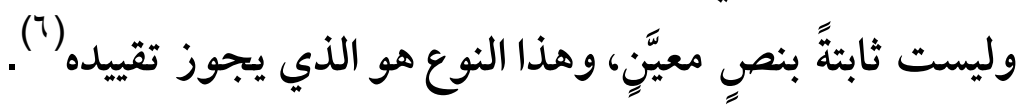

$$
\begin{aligned}
& \text { (1) سورة البقرة، من الآية ( Y Y ) ). }
\end{aligned}
$$

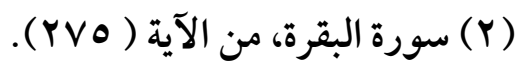

$$
\begin{aligned}
& \text { (r) سورة المائدة، من الآية (r) (Y). } \\
& \text { ( ) سورة البقرة، من الآية (Yq). } \\
& \text { (0) سورة الجاثية، من الآية ( س ا ). }
\end{aligned}
$$

(7) علم أصول الفقه للشيخ عبدالوهاب خلاف ، ص(1 1 ) )ط مكتبة الدعوة الإسلامية 
(7r)

\section{المبحث الثاني}

\section{ضوابط تقييد المباح}

تقييد وليّ الأمـر للمبـاح يـدخل ضـمن السياسة الشرعية، التي يـراد منها

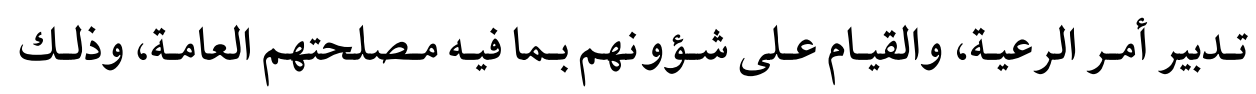

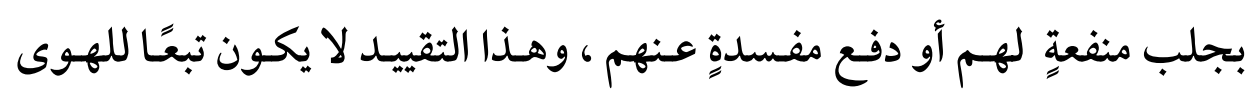

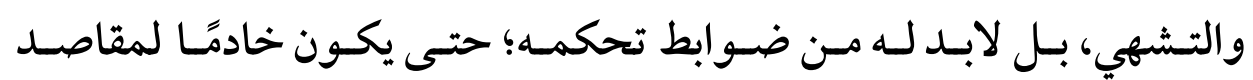

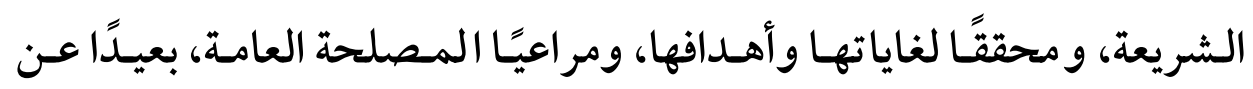

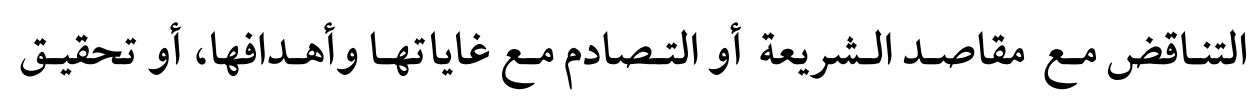
مصلحةٍ خاصةٍة، ومن هذه الضوابط :

\section{أولًا: أن يكون التصرف في مصلحةٍ عاملٍ لا خاصةٍ:}

فلا يجوز للمسلم أن يتصرف في الإباحة منعًا منها أو إيجابًا لها؛ لأن

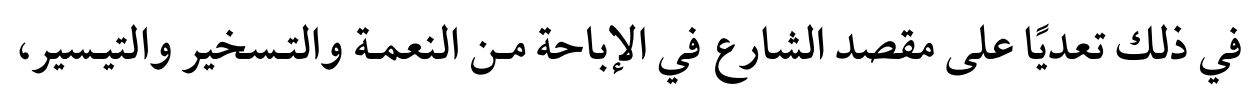

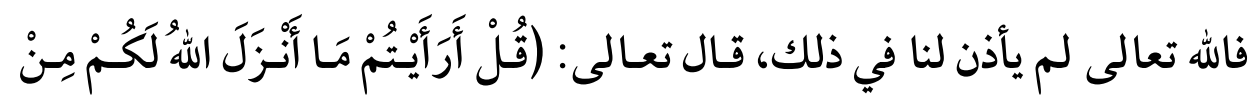

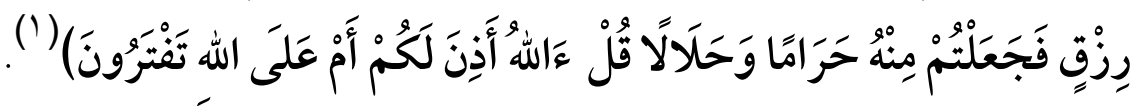

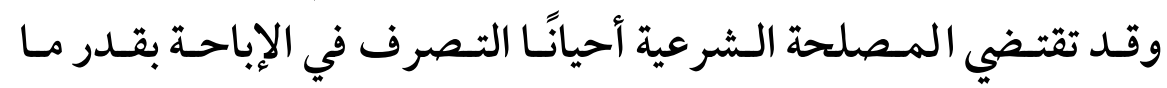
يحقق تلك المصلحة بجلب منفعةٍ أو دفع مفسدةٍ، لكسن هـذه المصلحة التي

وشباب الأزهر، وتقييد المباح للحسين الموس، ص(T) (Y)، ونور الصباح في فقه تقييد المباح، أحمد خالد الطحان، ص(A،V) شبكة الألوكة.

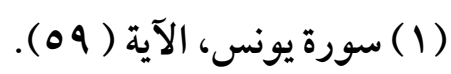


(TrY)

سلطة ولي الأمر في تقييد العريات السياسية للمصلحة العامة

تقتضي التصرف في الإباحة لابد أن تكون مصلحةً عامةًّ، لا مصلحةً خاصةًّ،

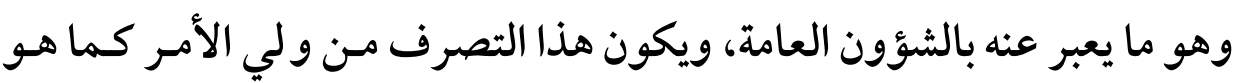

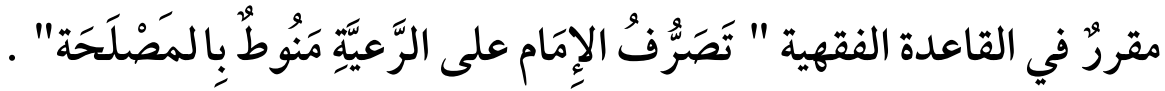

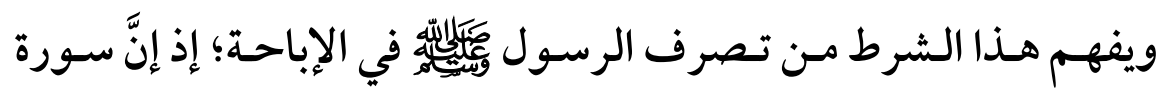

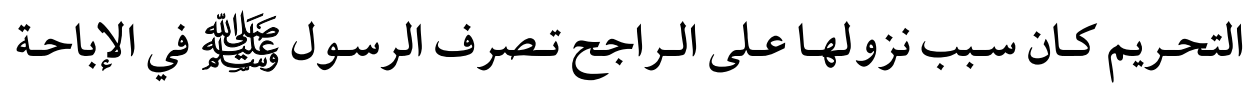

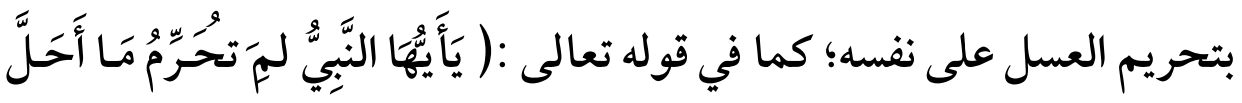

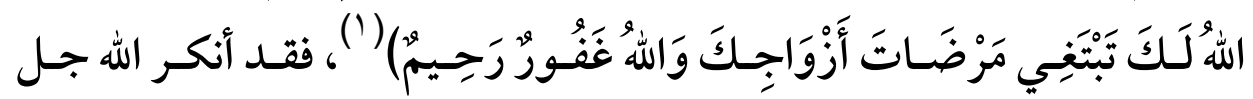

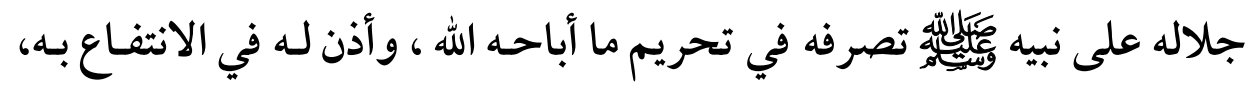

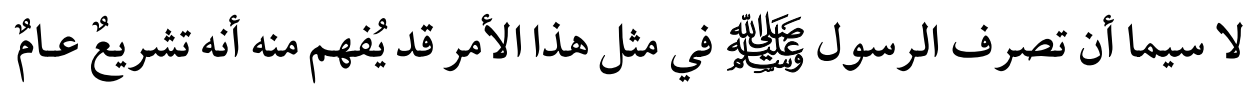

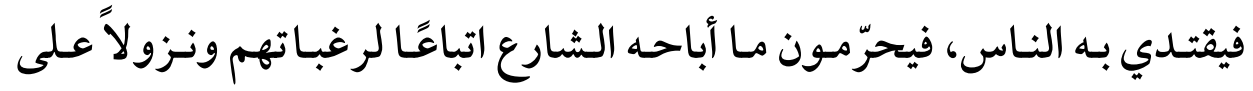
شهواتهم، وذلك أمرّ لم يُرِده الشارع ولم يقصده البتة.

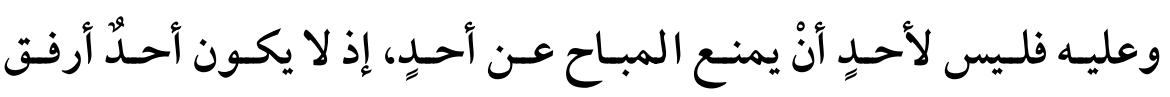

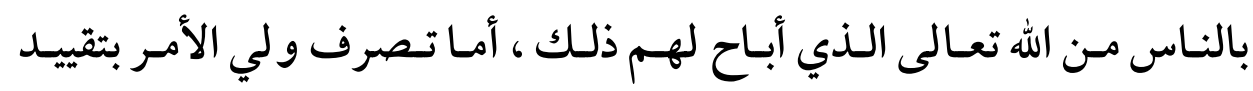

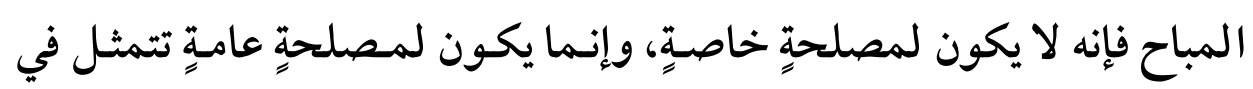
جلب منفعةٍ أو دفع مفسدةٍ.

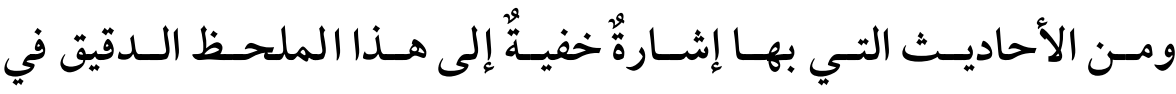

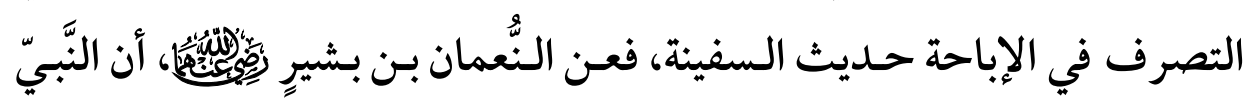

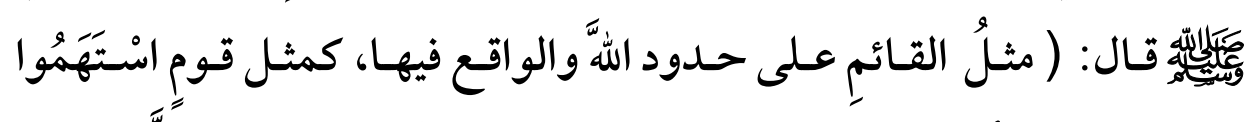

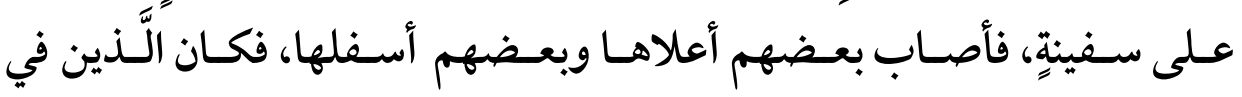

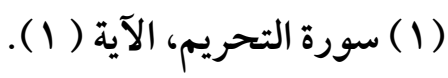




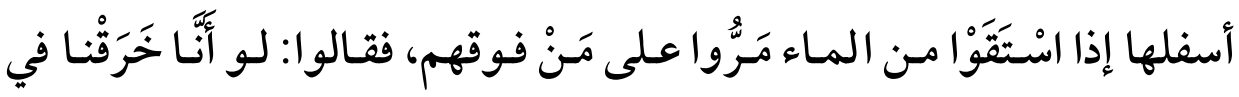

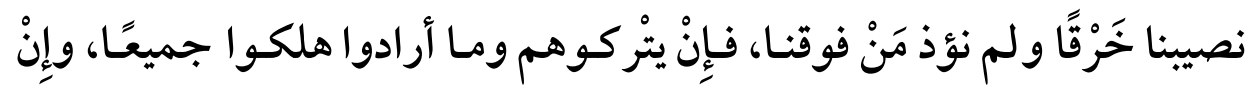
أخذوا على أيديهم نجَوْا، وَنَجَجْوا جميعًا ) ('). يفهم مـن هـذا الحـديث عـن طريت الإشـارة والتنبيـه : جـواز التصرف في الإباحة بالمنع إذا ترتب على الفعل المباح مفسدة عامة، فتصرف الإنسان في

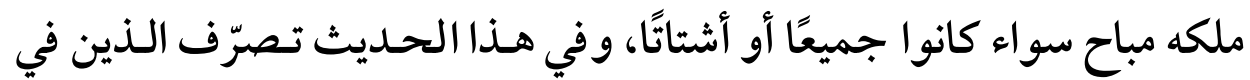
أسفل السفينة هو تصرّف مشروعٌ؛ لأنه في نصيبهم الذي يملكونه، ولكن في

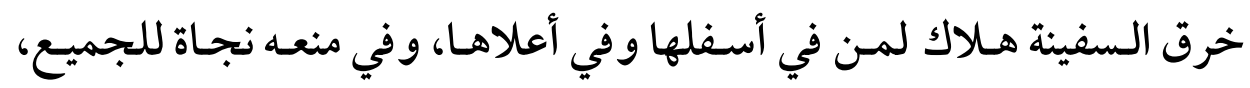
فيتعيّن منعه من تصرّفٍ مباحٍ؛ لما يترتّب عليه مفسدة عامة.

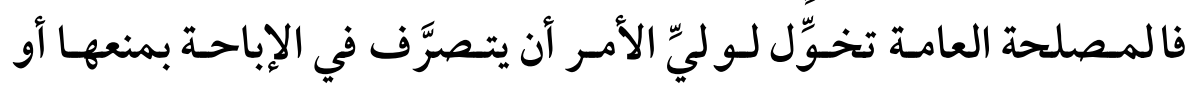
الإلزام بها، دون المصلحة الخاصـة. ونجـد في اجتهادات الصحابة مـايؤيـد

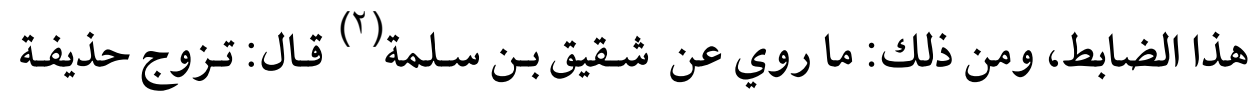
يهودية، فكتب إليه عمر : خَلِّ سبيلها، فكتب إليه: أتزعم أنها

(1) أخرجه البخاري في صحيحه، كتاب الشركة، باب هَلْ يُقْرَع في القِسْمة والاستهام

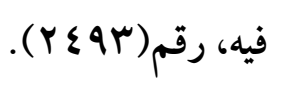
(Y) هو: شقيق بن سلمة أبو وائل الأسدي ، أدرك النبي صلى الله عليه و سلم ولم يسمع عنه، وهو صاحب عبد الله بن مسعود.

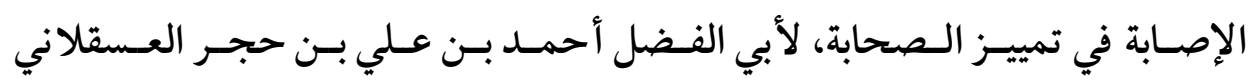

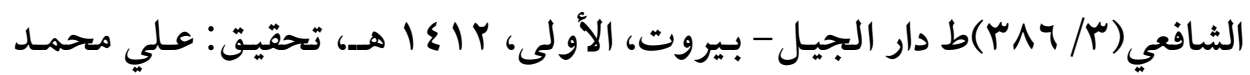

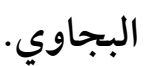


(7rq) سلطة ولي الأمر في تقييل الحريات السياسية للصلحة العافة

حر ام فأُخَلِّي سبيلها؟ فقال: لا أزعم أنها حـر امُ، ولكني أخحاف أن تعاطوا

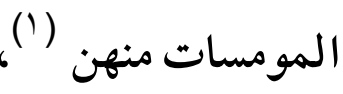

وروى أن طلحة بن عبيد الله نكح بنت عظيم اليهود قال فعزم عليه عمر

إلا ما طلقها (r) - (ب)

قال الطبري : وإنـما ذكـره عمـر لطلحـة وحذيفـة رحمـة الله عليهم نكـاحَ

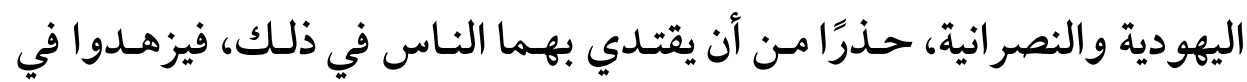

المسلمات، أو لغير ذلك من المعاني، فأمر هما بتخليتهما (r).

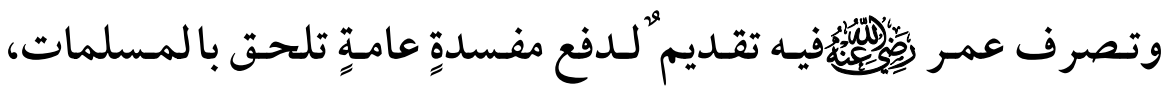

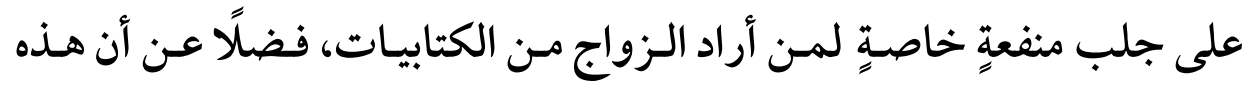
المنفعـة تتحقـق بـالزواج مـن المسلمات، ولعـل هـذا الاجتهـاد الـصادر مـن

(1) أخرجه ابـن أبي شـيبة في مصنفه، كتاب النكاح، مـن كـان يَكْره النّكـاح في أهـل

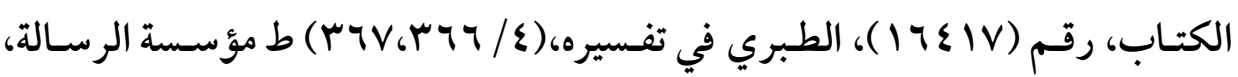

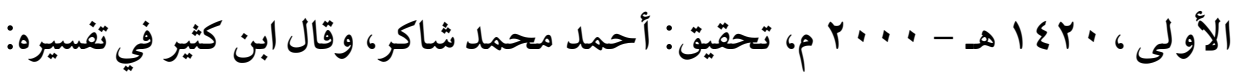

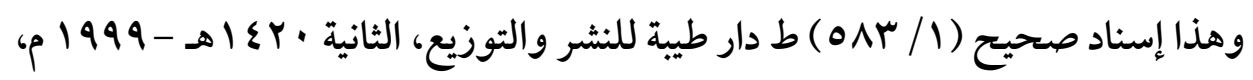
تحقيق سامي بن محمد سلامة.

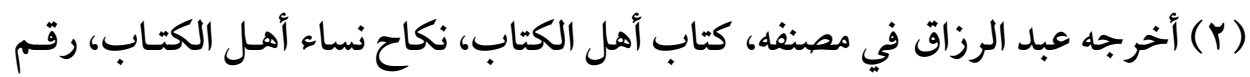
. (1..09)

(r) أخرجه ابـن أبي شـيبة في مصنفه، كتـاب النكاح، مـن كـان يَكْره النّكـاح في أهـل

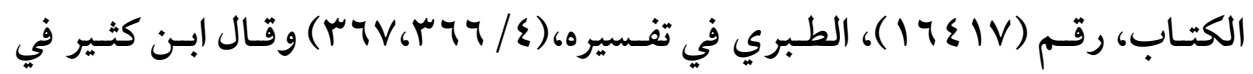
تفسيره: وهذا إسنادصحيح (1/ ریمه ). 
(7ro)

الفاروق عمر هو الذي جعل الإمام الشافعي يميل إلى القـول باستحباب تـرك

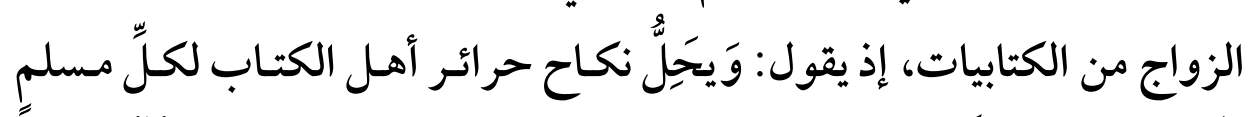

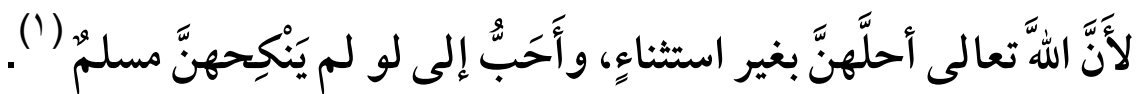

ثانيًا: أن هذا التصرف ليس حكثًا لازمًا ولا دائمًا :

فتصرف الإمـام في الإباحة يكسون تصرفًا مؤقتًا ، إمـا في إمامتهـ أو بعـدها،

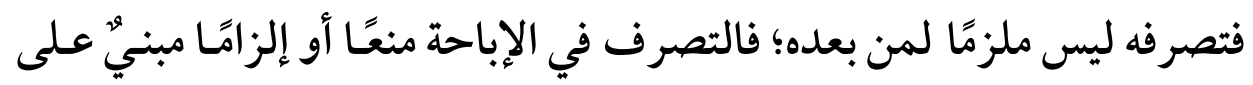

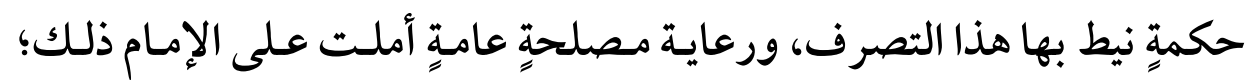
لأن تصرفه على الرعية منوط بالمصلحة.

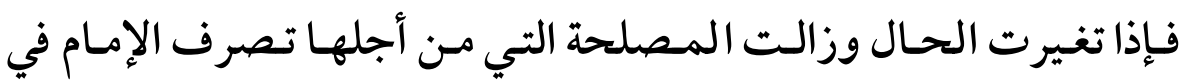
المبـاح فينبغـي عليـه أن يعـود إلى حكــم الأصـل وهـو الإباحـة، ويخـلي بـين

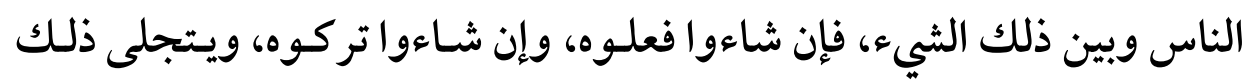

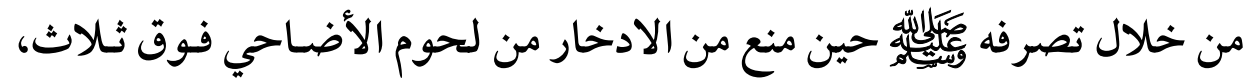

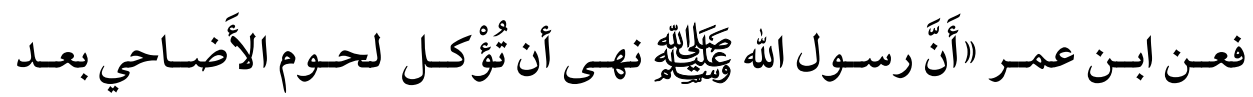

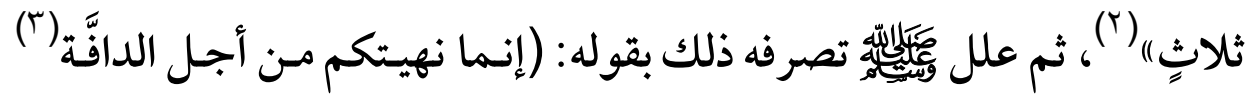

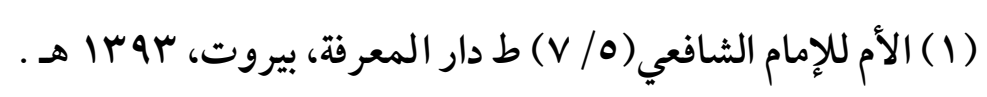

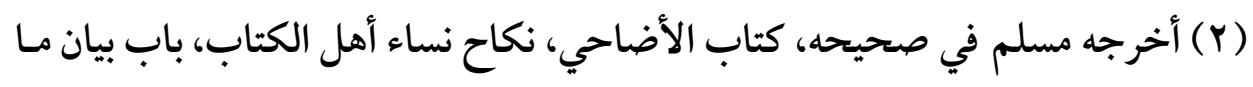
كان من النَّي عن أكل لحوم الأضاحيِّ بعد ثلاثٍ في أول الإسلام، رقم ( • (19V) ).

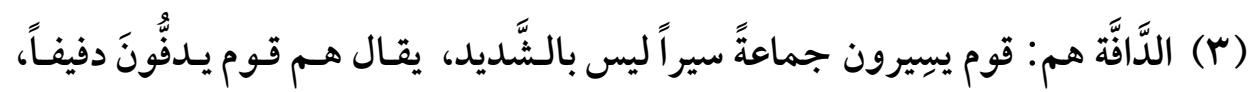

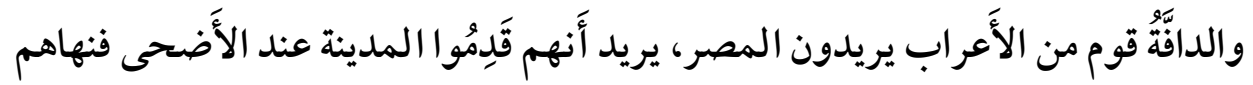

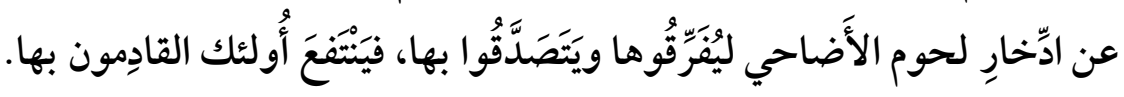


(7ry)

سلطة ولي الأمر في تقييد العريات السياسية للمصلحة العامة

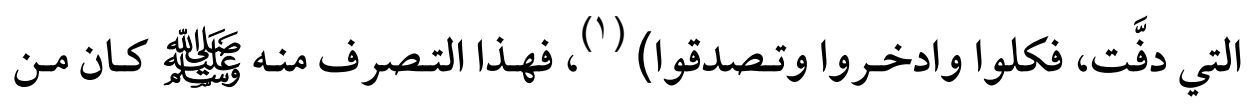

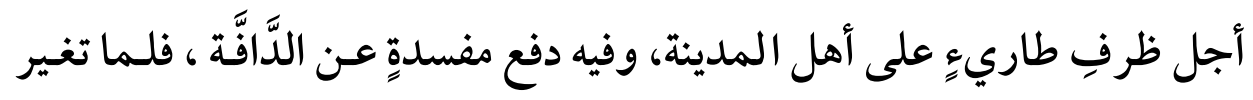

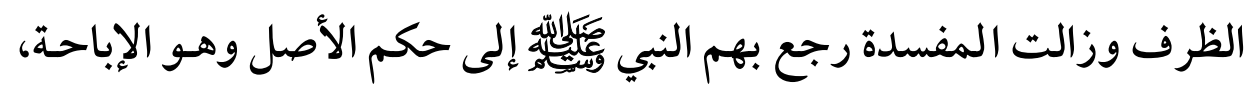

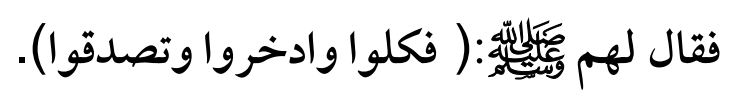

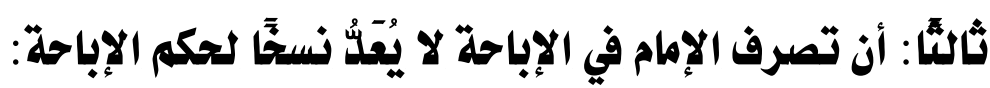
تصرّ ف الإمام في الإباحة ليس من قبيل النسخ؛ لأنه ليس هنـاك نسخ بعـد

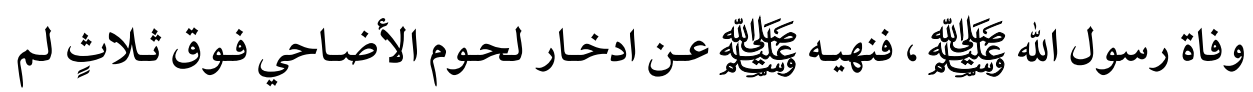

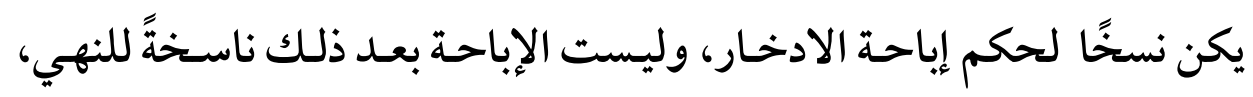

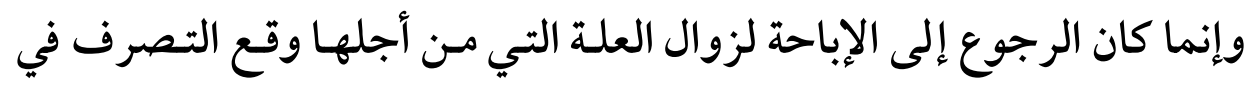

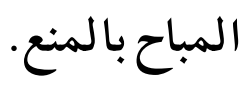

رابقًا: ليس للإمام أن يمنع جنس المباح بل له فقط أن يمنع الفرد من

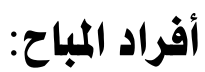

فليس لأحـد أن يمنـع جـنس المبـاح؛ لأنـه بـذلك يخـالف النص الشرعي

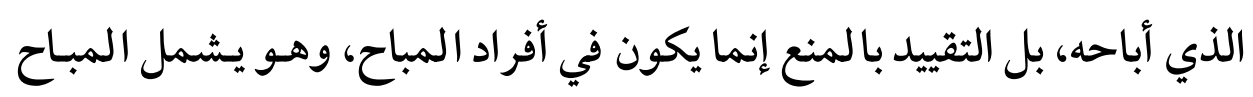

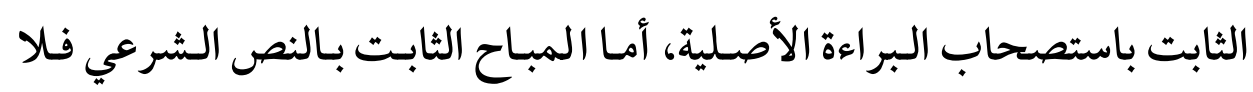

لسان العرب، مادة (دفف)(9/9 ع • (1). (1) أخرجه مسلم في صحيحه، كتاب الأضاحي، نكاح نساء أهل الكتاب، باب بيان مـا كان من النَّي عن أكل لحوم الأضاحيّ بعد ثلاثٍ في أول الإسلام، رقم (19VI ) . 
يملك أحد تقييده ؛ لأنه تشريع وهو من خصائص الله تعالى، ومن خصائص

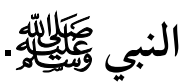

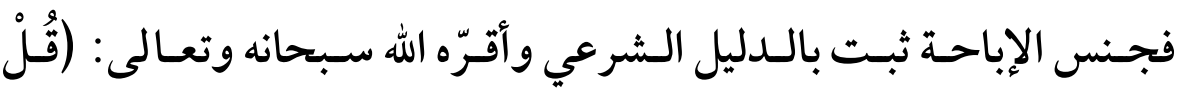

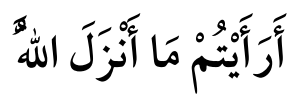

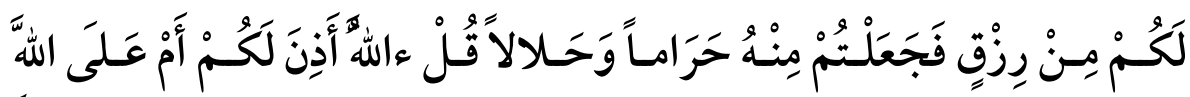

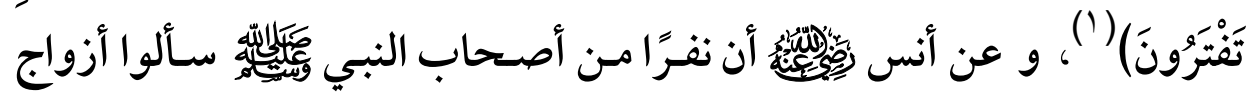

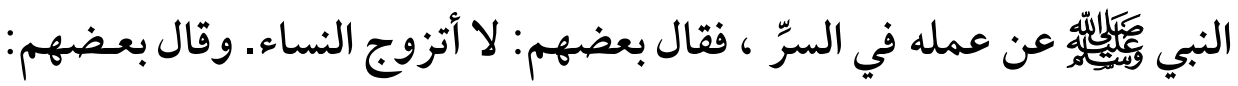

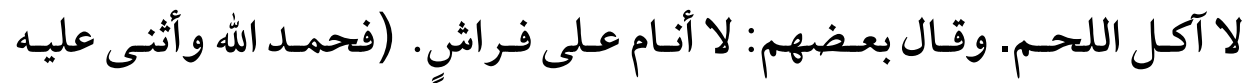
فقال: ما بال أقوام قالوا كذا وكذا، لكني أصلي وأنام، وأصوم و أفطر، وأتززوج

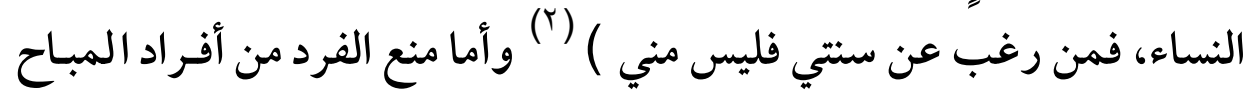
في حالة معيّنة، ولوقت معيّن، فجائز.

خامشا: أن يكون المباح مما جعل للإمام حق التصرّف فيه بسياسته

\section{واجتهاده:}

إذا كــان المبــاح متعلقَّا بالـشؤون العامـة أو بــشؤون الدولــة الخاصــة كالشؤون المتعلقة بالجيش، أو كإلزام موظفي الدولة بأوقاتِ معينةٍِّ وأعمالٍ

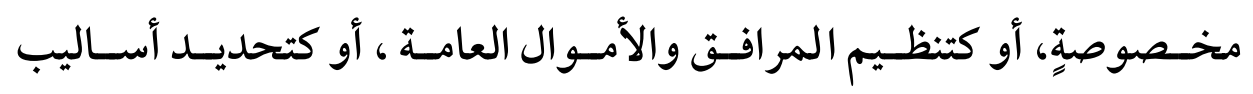

$$
\text { (1) (1) سورة يونس، الآية (ه) (1). }
$$

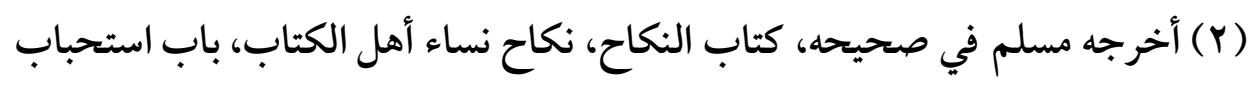

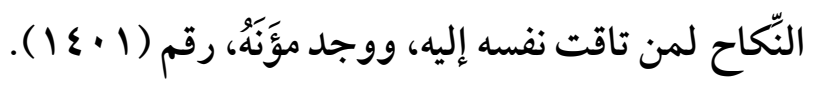




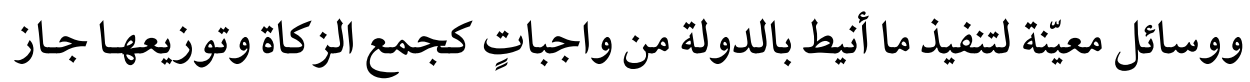
للإِمام تقييدها بالمنع أو الإلزام.

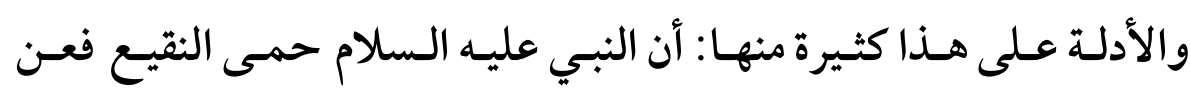

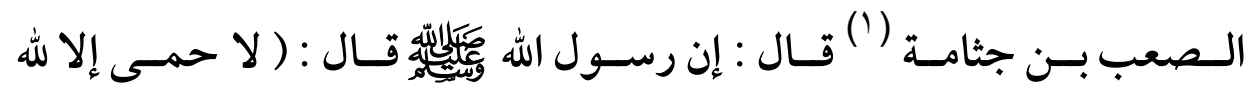

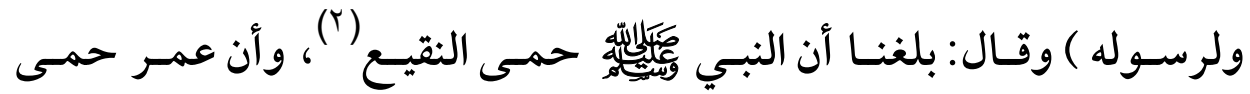

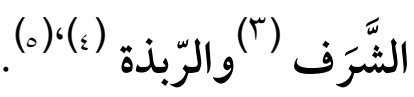

(1) هو: الصحابي الجليل الصعب بـن جثامة بـن قيس بـن ربيعة هـاجر إلى النبي ، وعداده في أهل الطائف مات في آخر خلافة عمر.

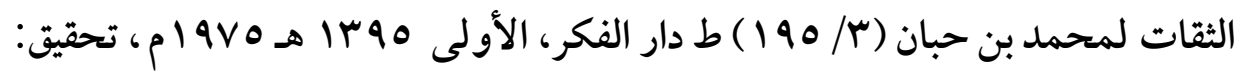
السيد شرف الدين أحمد.

(Y) النقيع هو : موضع قرب المدينة، كان رسول الله حماه لخيله، وبين النقيع والمدينة

$$
\text { عشرون فرسخا ، ومساحته ميل في بريد. }
$$

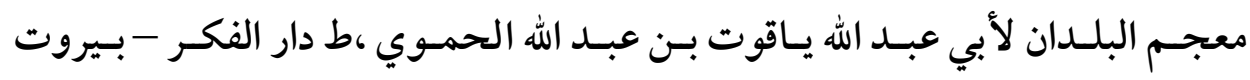

$$
\text { . }\left(r \cdot r_{6} r \cdot 1 / 0\right)
$$

(r) الشرف هو : المكان العالي ، وهو كبد نجد ، و كانت منازل بن آكل المرار من كندة

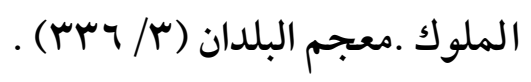

( ) الربذة: قرية بنجد من عمل المدينة ، بينها وبين المدينة ثلاثة مر احل ، قريبة مـن

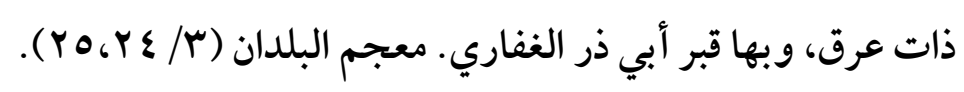

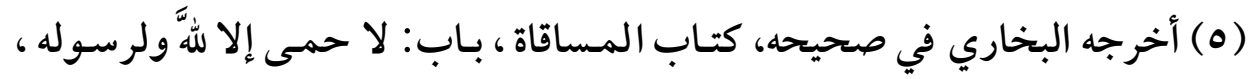


واسترجع منجم الملح الذي أقطعه أبيض بـن حمَّال ( ') بعدما تبيّن لـه أنه

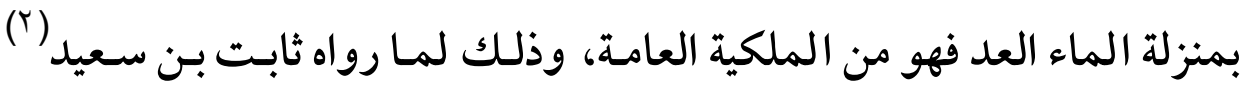

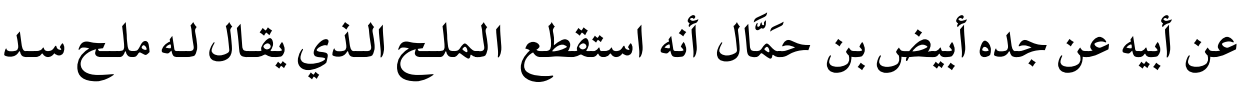

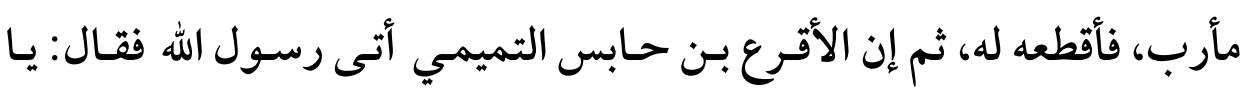

(1) أبيض بن حمَّال هو : الصحابي الجليل أبيض بن حمـال بـن مرثـد بـن ذي لحيان

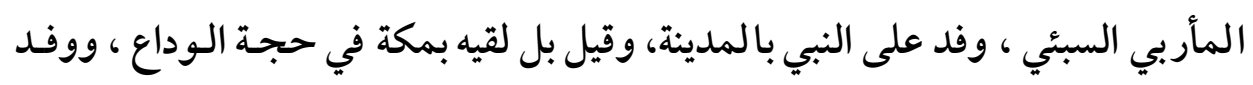

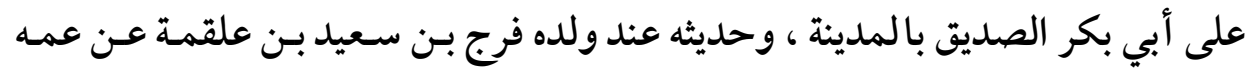

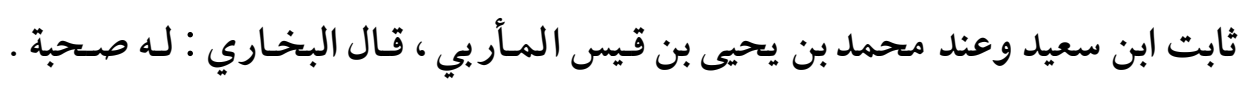

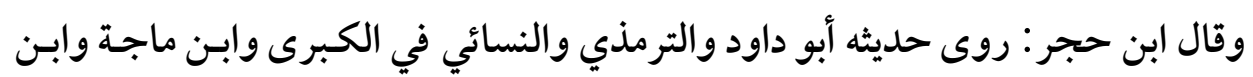
حبان في صحيحه .

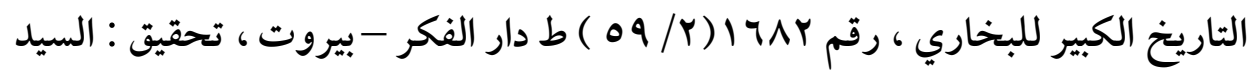

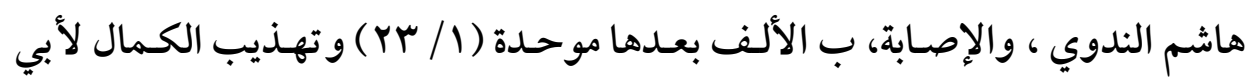

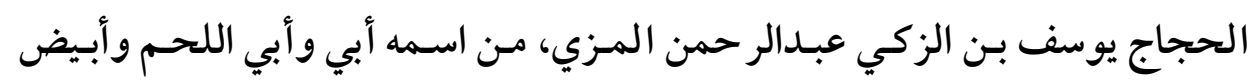

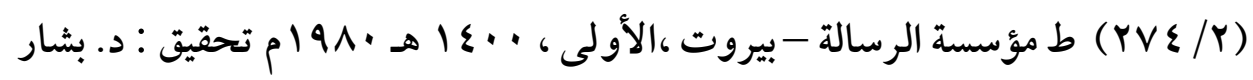
عواد معروف.

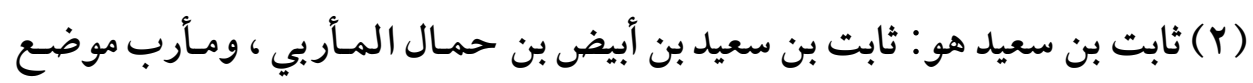

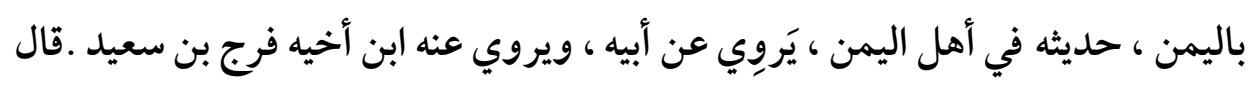

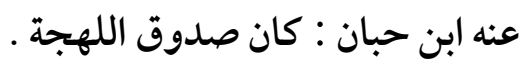

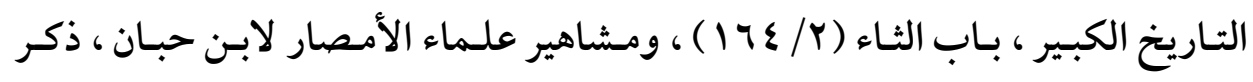

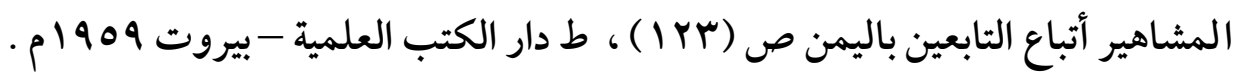




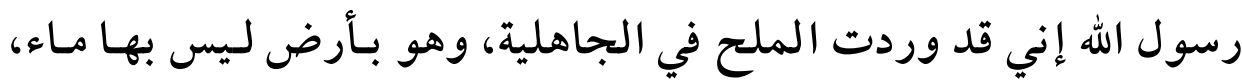

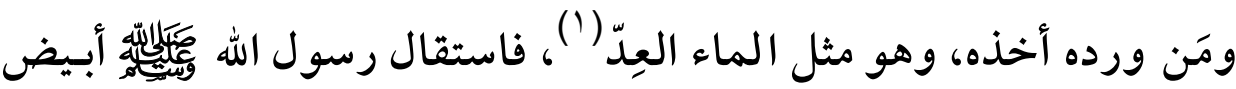

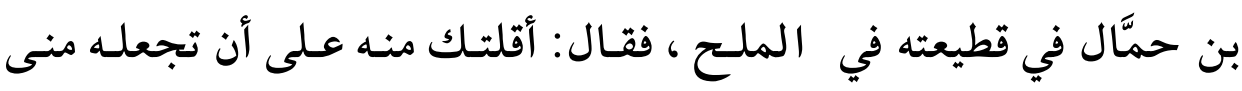

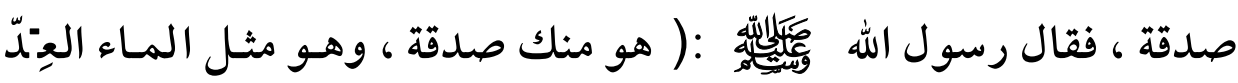

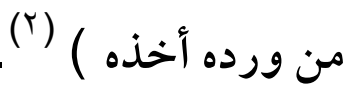
وأمر بجعل الطريق الميتاء سبعة أذرع لتنظيم السير فيها، وذلك لمـا روي

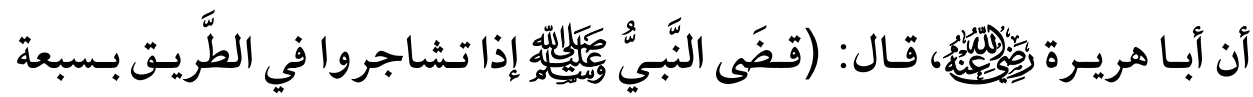
أذرعٍ) (َ)، وغير ذلك من التصرفات التي تحدّد طبيعة تقييد المباح ومـا للإمـام

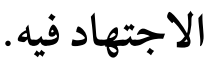

(1) الماء العِدّ هو : الماء الدائم الذي لا انقطاع لمادته ، قال الأصمعي : المـاء العِدّد :

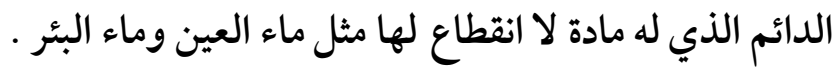

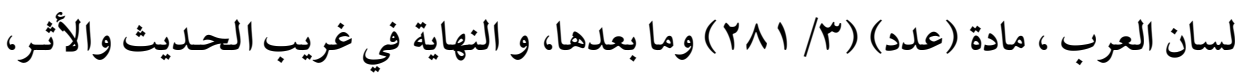

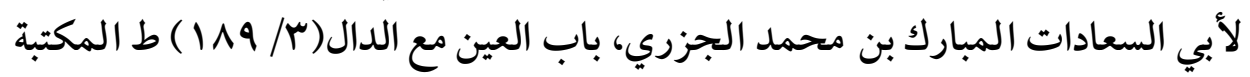

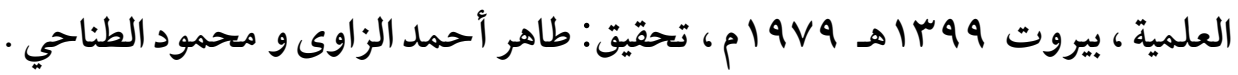

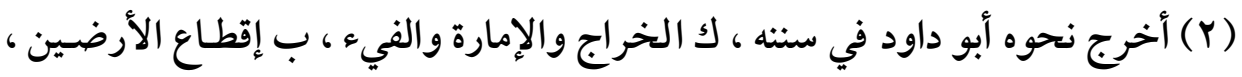

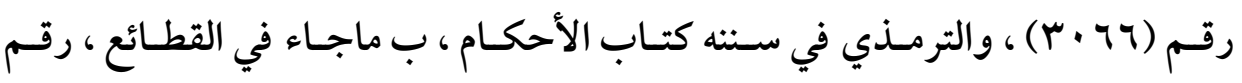

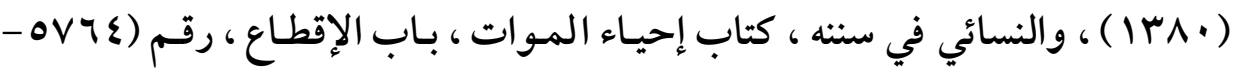

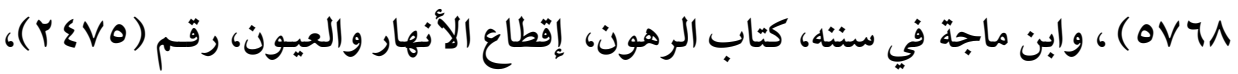

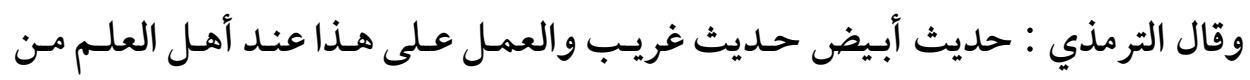

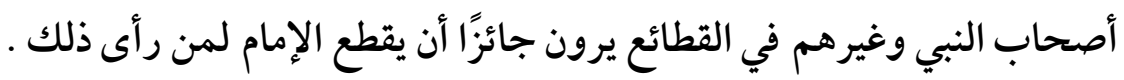

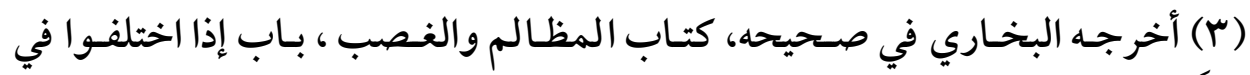

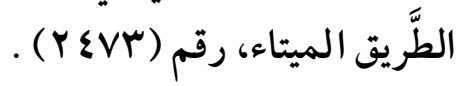


(7\&1)

وعليه فإنّ ما سلف ذكره يبيّن أنّ إذن الشارع للإمـام بتقييد المبـاح يتعلّق

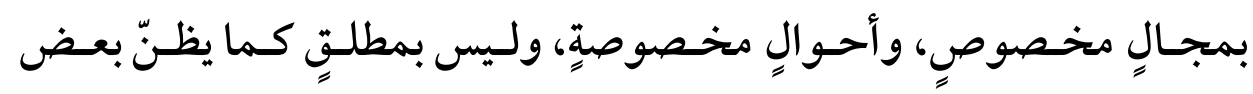

الناس.

\section{سادسًا: موافقة الشرع :}

فما جاءت إباحته بالنص لا يجـوز تقييـده أو منعـه أو الإلززام بـه على صـفة

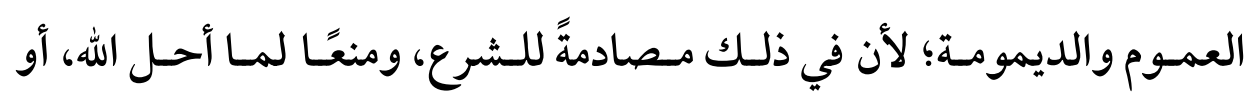
إيجابًا لما أباحه الشرع ولم يلزم به.

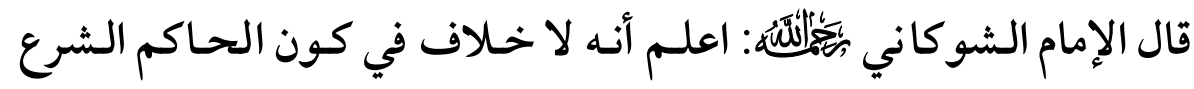

$$
\text { بعد البعثة، وبلوغ الدعوة ('). }
$$

ولسو كانـت هنـاك ضرورات ملجئَة أو حاجـات عامـة لنوع مـن المنـع أو

التقييد أو الإلزام ولا يوجد حَلْ لها غير ذلك التصرف الضروري فِإن الأخـذ

بــه تكسون علتـه: الـضرورات تبسيح المحظـورات، فإنهـا تلجسئ إلى تقييـد المباحات، والحاجـات العامـة تنزل منزلة الضرورات، فهو منـع أو تقييد أو

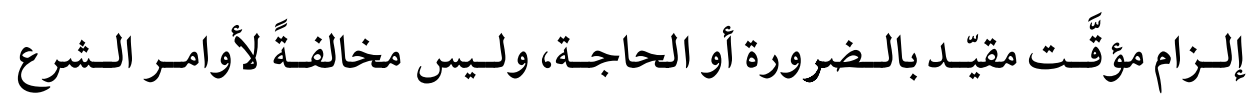
الحنيف.

(1) إرشاد الفحول إلي تحقيق الحقق مـن علم الأصسول لمحمد بـن علي بـن محمـد

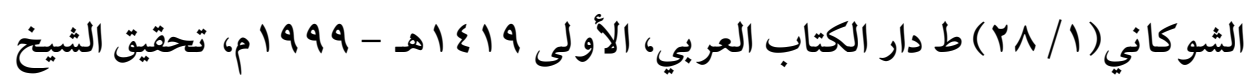
أحمدعزو عناية . 


\section{سابعًا: مواققة مقاصل الشريعة:}

ينبغي أن يكسون كـل تـصرف في المبـاح عـاملاً عـلى تحقيـق مقـصدٍ مـن

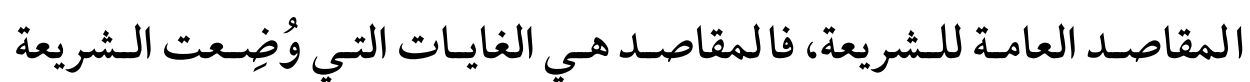

لأجل تحقيقها لمصلحة العباد.

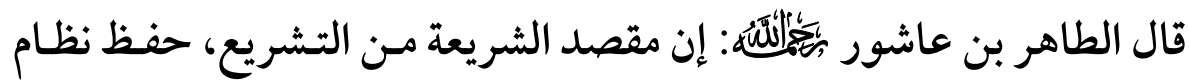

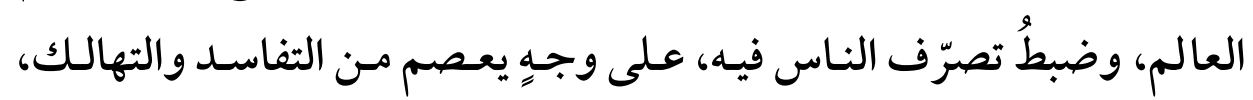

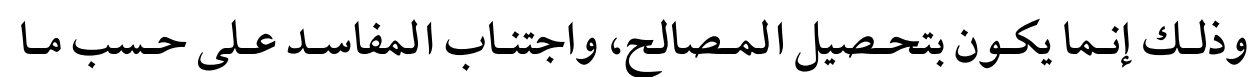

يتحقق به معنى المصلحة والمفسدة (')

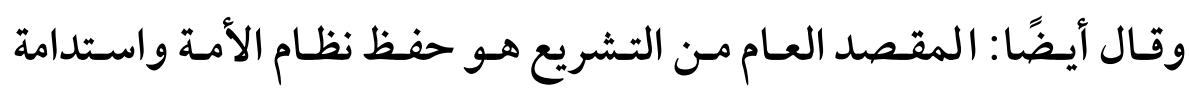

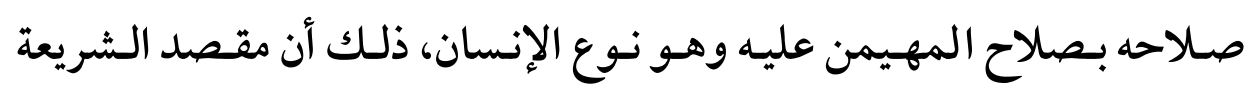

أساساً وبالذات هو الإصلاح وإزالة الفساد(؟).

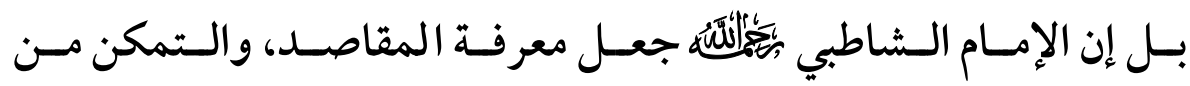

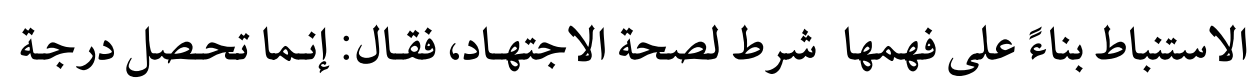
الاجتهاد لمن اتصف بوصفين:أحدهما: فَهْم مقاصـد الشريعة على كمالها.

والثاني: المُمَكَّنْ من الاستنباط بناءً على فهمه فيها (ب).

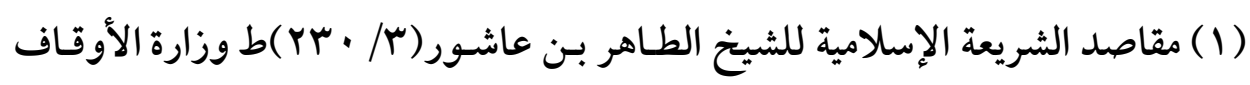

$$
\text { والشؤون الإسلامية بقطر، ؟ . . Y م. }
$$

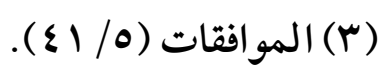




\section{ثامثًا: التقييد لا يكون إلا للضرورة الملجئة:}

لا يـتم التصرف في المبـاح بتقييـده عـلى الإطلاق وإنـما يكسون في حالـةٍ

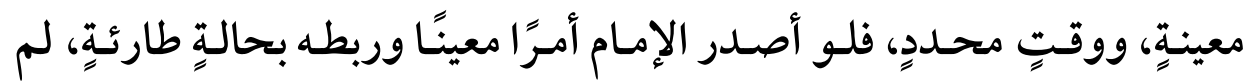

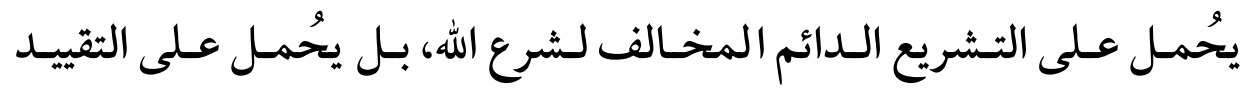
الطارئ المرتبط بالظرف أو الحالة الملجئة إليه، يوجـد بوجودهـا ، فبإذا زال الظرف الطارئ أو الحالة الملجئة عاد الأمر إلى الإباحة الأصلية مرةً أخرى.

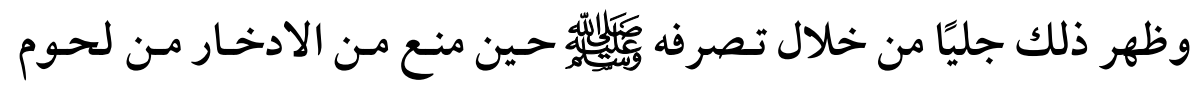

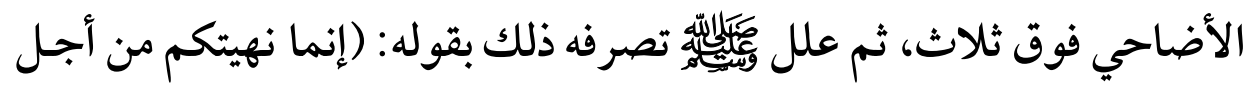

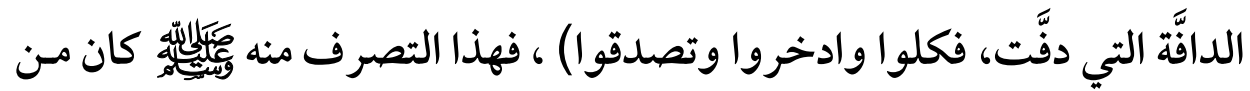
أجل ظرفٍ طاريئ على أهل المدينة، وفيه دفع مفسدةٍ عـن الدَّافَّة ، فلـما تغير

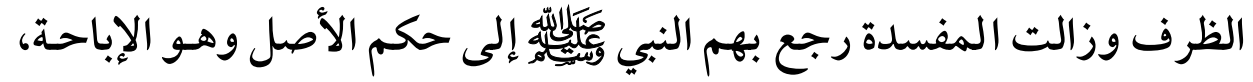

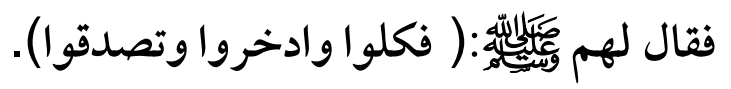

تاسقا: أن يقوم على تقييد المباح أهل العلم والثقه والاجتهاد:

فتقييــ المبـاح بـالمنع أو الإلـزام ينبغـي أن يكسون صـادرًا مـن أهـل العلـم والفقه والاجتهاد؛ حتى يكون محققًا الغرض الذي من أجله تم تقييد المبـاح، ولا يترتب عليه نتائج عكسية .

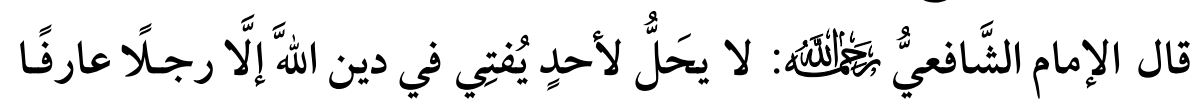

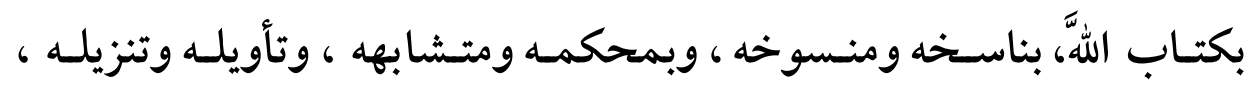

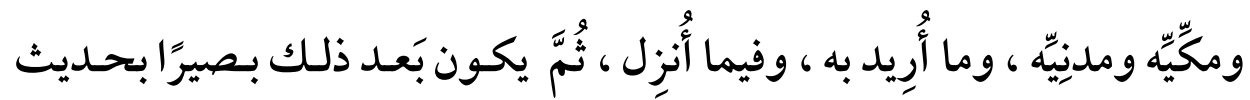

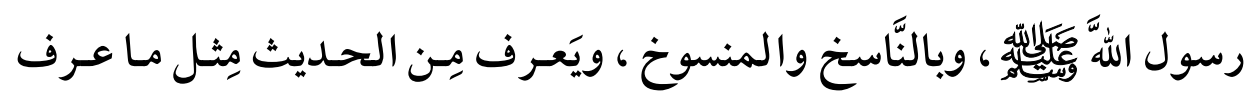


( $า \varepsilon \varepsilon)$ سلطة ولي الأمر في تقييل العريات السياسية للصصلحة العاهة

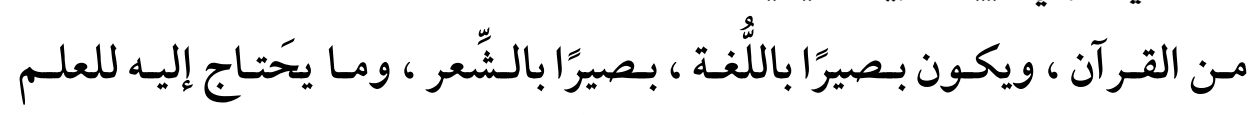

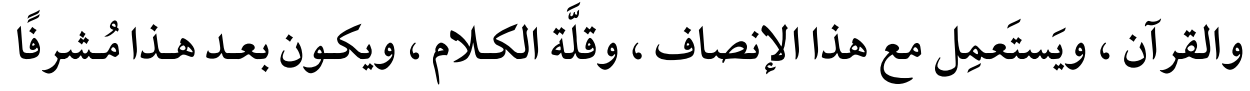

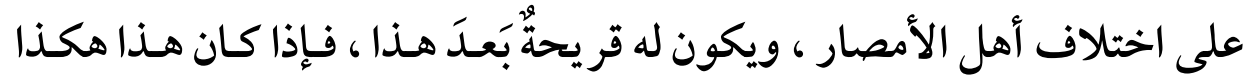

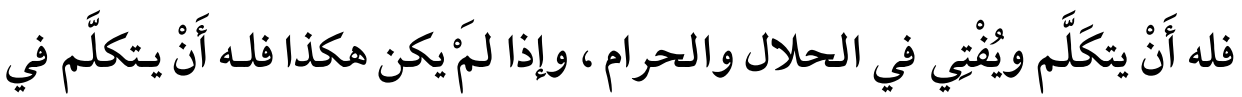
العلم ولا يُفْتِي (') - (')

\section{عاشرًا: توفير البلديل المباح عند المنع وتيسيره على الرعية:}

إذا كـان تقيــــ المبـاح بـالمنع فينبغـي عـلى الإمـام حينئـذ تـوفير البـدائل الشرعية التي تغني عن المباح الذي منع منه قدر الإمكان، فمبنى الشريعة على لى التيسير وذم التعسير.

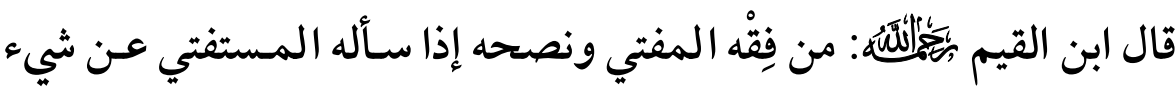

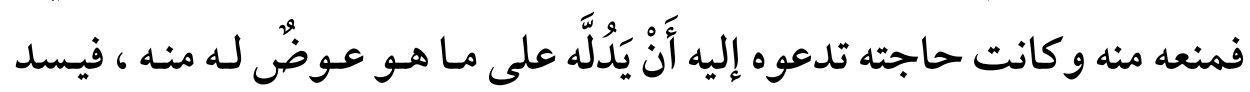
عليه باب المحظور، ويفتح له باب المباح، وهذا لا يتأتى إلا مـن عـالمٍ ناصِح

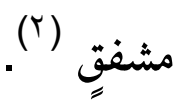

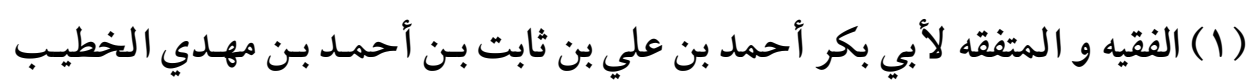

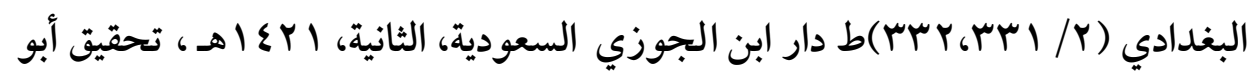
عبد الر حمن عادل بن يوسف الغرازي.

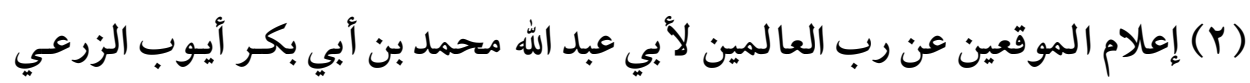

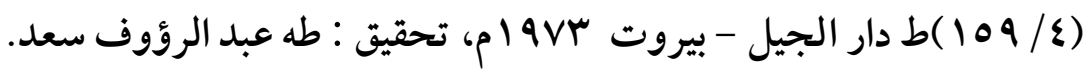


(7ะ0)

وإذا كان هذا شأن المفتي الذي ليس له سلطان على المكلفف، فإنه حري بالإمام الذي له سلطة الإلزام أن يوفر للرعية ما يعوضها عن المباح الذي وقـع عليه التقييد أو المنع. حادي عشر : تعويض المتضرر من التقييد عند الاقتضاء:

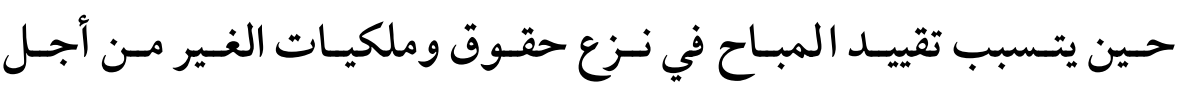
المصلحة العامة، أو إلزام آحـاد الرعية بـأعمالٍ ووظـائف لمصلحة الأمـة، أو إلحاق ضرر بالغير، فإن تعويض المتضرر يصبح أمرًا محتمًا يقوم بـه الإمـام

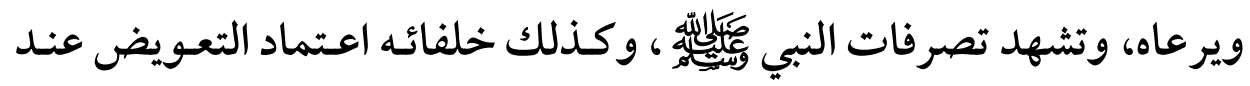
تقييد الحقوق أو نزعها، كما في قصة بناء المسجد النبوي ثم توسيعه على عهد الخلفاء الر اشدين ، ولا شك أن ذلك يقتضي تقييم الضرر، والمفاوضـة من أجل التقيم العادل، فمن أصول الثريعة العدل وإقامة القسط بين الناس.

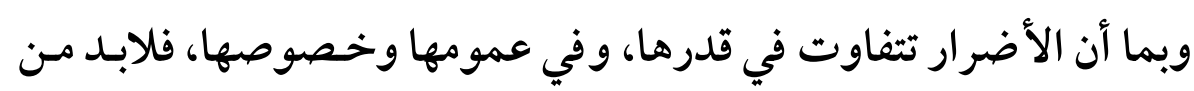
ميزانٍ دقيقٍ يعتمد للترجيح والموازنة ، بحيـث يتناسـب التعويض مـع الضرر الواقع، و كذلك القيد مع ما يترتب عليه من ضرر (' '.

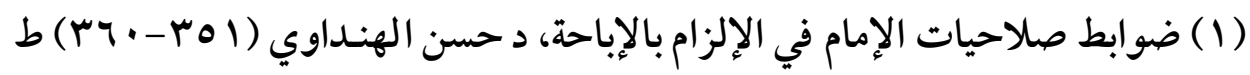

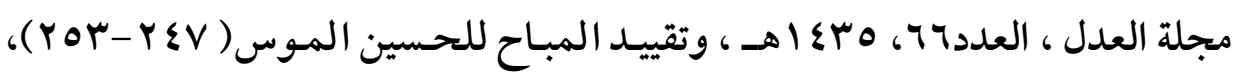
ونور الصباح في فقه تقييد المباح (V-9). 


\section{المبحث الثالث}

\section{نهاذج لتقييد المباج بضوابطه}

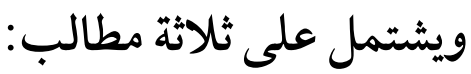

\section{المطاب الأول \\ الأكل والشرب هن الطيبات}

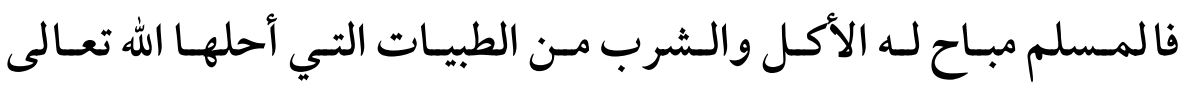

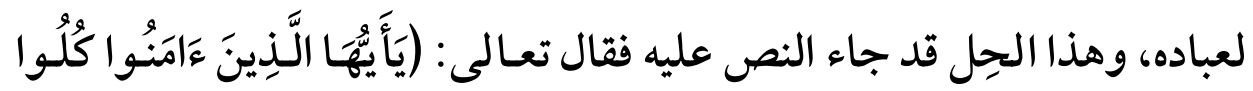

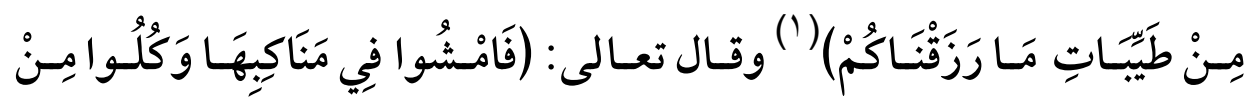

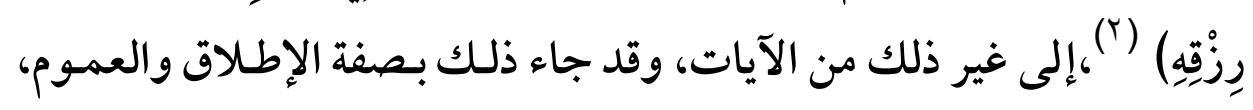

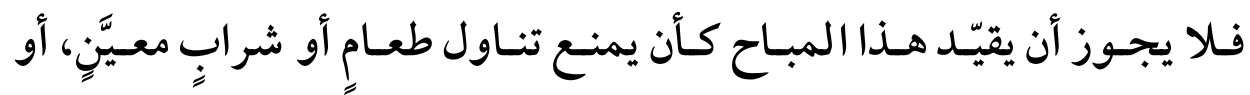
يحدد الكمية التي يتناو لها الفرد؛ لأن صسورة القيد هنا صـورة التشريع؛ لأنه

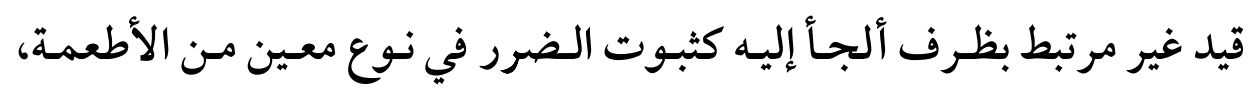

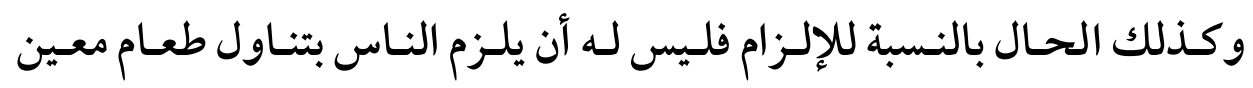
ونحو ذلك، لكن لو قدر أنه حصل تناقص في الأقوات و أصبحت الأقوات لا تكفي للشعب فهنـا قـد تعـارض حكمان: حكـم إباحـة الأكل مـن الطيبـات وتناول الكمية التي يريدها، وحق كل مسلم في أن يجـد القوت الذي يسد بـه جوعته و يحفظ عليه حياته المـأمور با لمحافظة عليها، فهذا ظـرف ونس أو حسال يمكن أن تُلجئ إلى إصدار قانون ينظم هذا التناول لفترة محسددة، فلو أصـدر

$$
\text { (Y) (1) سورة البقرة، من الآية (IVY) (1). }
$$


ولي الأمر قرارًا ينظم هذه المسألة وربطه بتلك الحالة الطارئسة لم يحمل هـذا على التشريع الدائم المخـالف لشرع الله تعالى الممنوع منه كل أحـد أميرًا

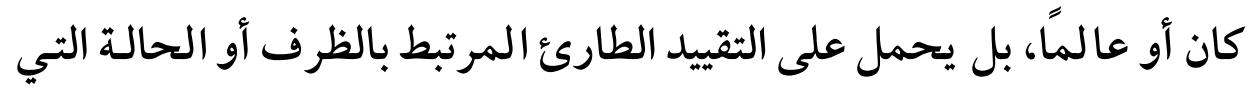

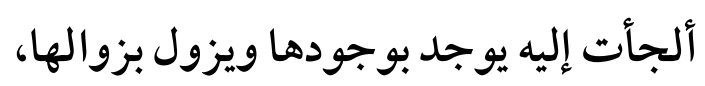

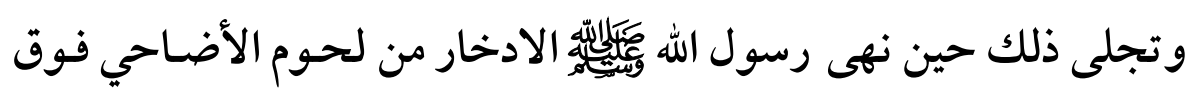

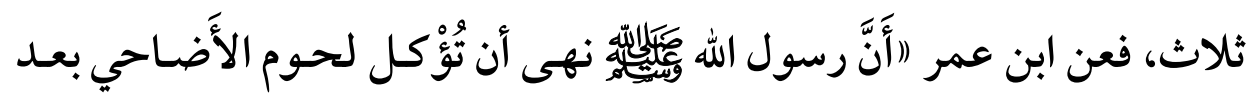

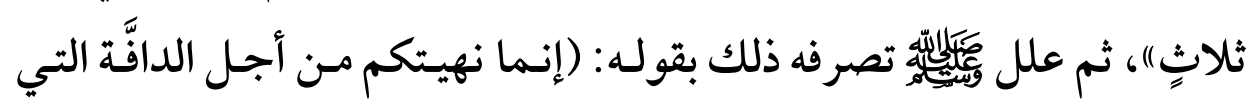

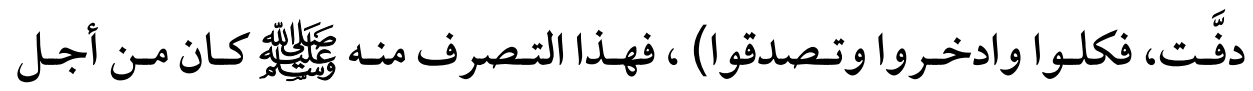

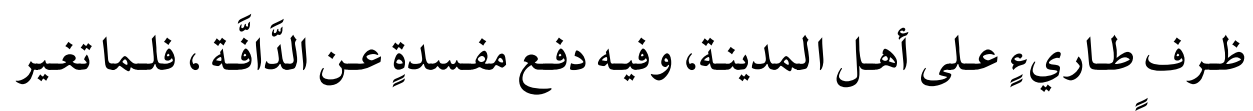

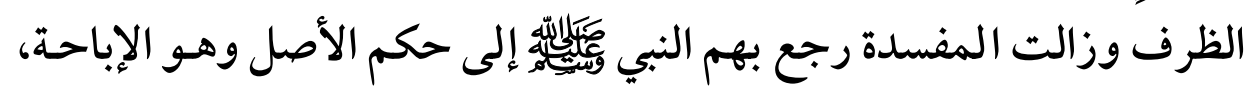

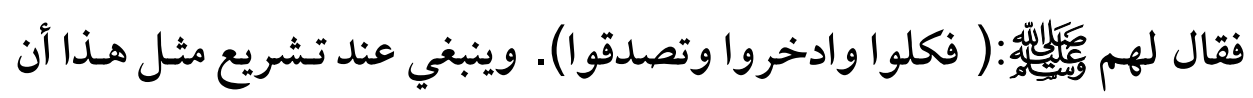

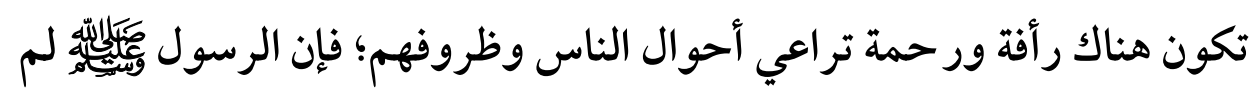

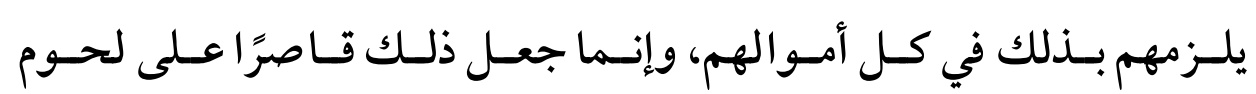


$(7 \varepsilon \wedge)$

سلطة ولي الأمر في تقييد العريات السياسية للمصلحة العامة

\section{الاطلب الثاني}

صيد البر والبحر

مـن المباحـات صسيد البر والبحـر لحاجـة الأكـل والانتفـاع، قـال تعـالى :

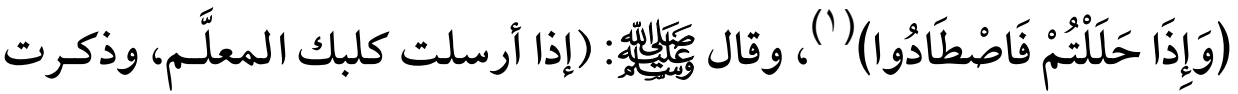

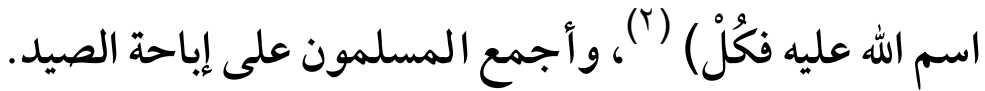

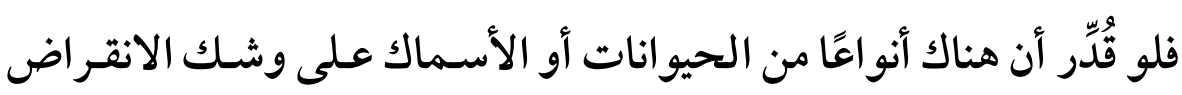
نتيجة كثرة الاستهلاك أو الذبح فبإذا قيَّد الحساكم الذبح بكونه في الذكور لات الا في الإنـاث، وقيَّـد صسيد الأسـماك بالأحجـام الكبيرة دون الأحجـام الصغيرة

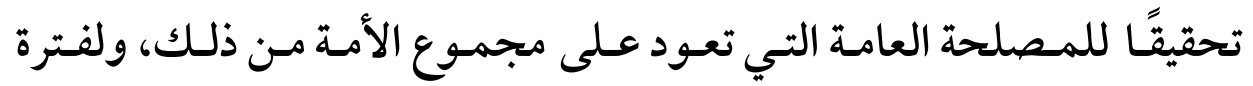

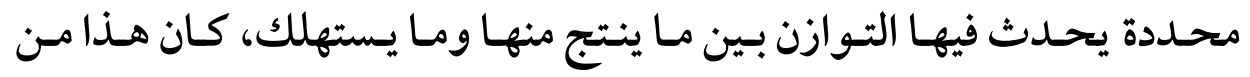
التقييد الذي يظهر منه أنه تقييد للمصلحة بعكس مـا لو كـان التقييد لترويج سلعة بعض أصـدقائه أو أقاربـه، بحيـث لا يكسون لها منـافس في الأسـواق لم

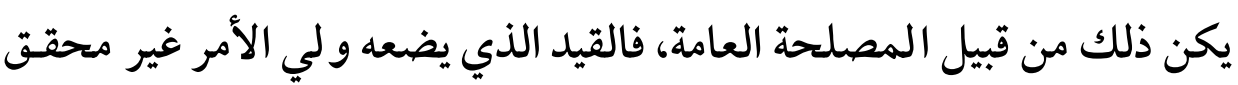
للمصلحة فهو قيد وضع بخلاف القاعدة التي أجـازت لـه ذلك، فبإذا خالفها

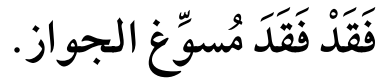

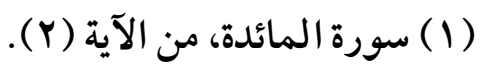

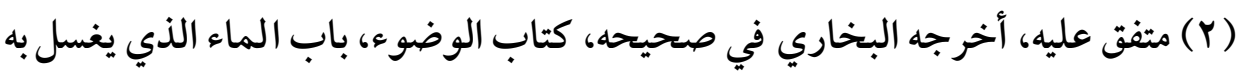
شعر الإنسان ، رقم(IVO) )، ومسلم في صحيحه، كتاب الصيد والذبائح، باب الصيد بالكلاب المعلمة ، رقم(9 (999 )، واللفظ لمسلم. 


\section{الاملب الثالث \\ السكنى والبنهاء}

إباحة السكنى في أي بقعةٍ من دار الإسلام:

يباح للمسسلم السكنى في أي بقعـة مـن دار الإسلام، يقيم فيها متى شـاء،

ويرحل عنها إذا شاء، ولا يجوز لأحـد أن يقيّدّد إقامته فيجعلها في مكان دون

آخر، أو أن يحظر عليه دخول بعض المدن ونحو ذلك، لكن قـد توجـد بعض

الأحوال التي تبيح هذا التقييد إذا كان يترتب عليه مصلحة عامة، ومن ذلك مـا

فعله عمر رضي الله تعالى عنه حيـما منع كبار الصحابة من مغادرة المدينة

واسـتبقاهم إلى جانبـه ليكونـوا لـه بمثابـة المـشيرين الـذين يرجـع إلـيهم إذا

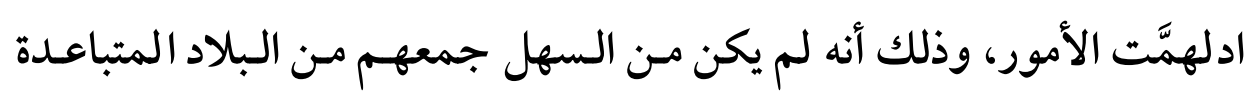

في وقـت قصير لو تفرقواعـن المدينة، ولكـن في ظل وسـائل المواصـلات

والاتسـصالات الحديثـة يمكـن جمـع العـشرات بـل والمئسات في سـاعات

معدودة،

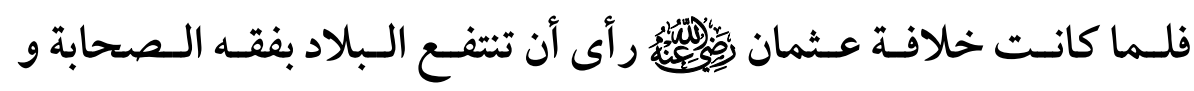

علمهـم، وينتفعـوا هـم بــما يـرون في البـلاد مـن حسضارة، فـرخص لهـم في

السفر (') - (1)

(1) فيض الخاطر لأحمد أمين(Y / / ) ط دار المحراب الأدبي للنشر والتوزيع. 
فمسن المباحسات بنـاء الإنسان مـصنعًا أو ورشـةً للـصيانة عـلى أرضٍٍ

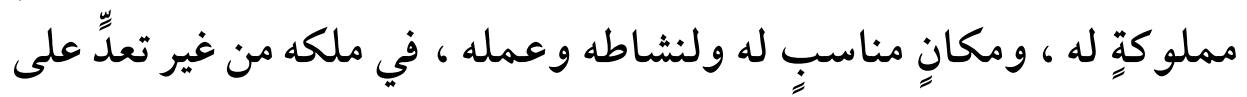
الآخرين، لكن إذا كانت هذه المصانع أو الورش من النوع الذّي تخرج

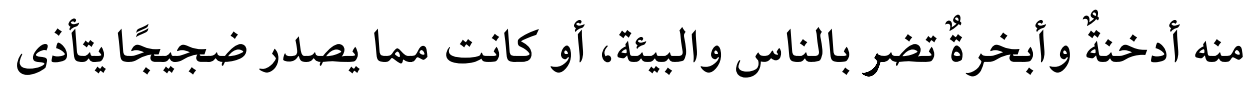
بسماعه الناس، وكل ما كان من هذا القبيل ونحوه فإن لولي الأمر أن يقيّد

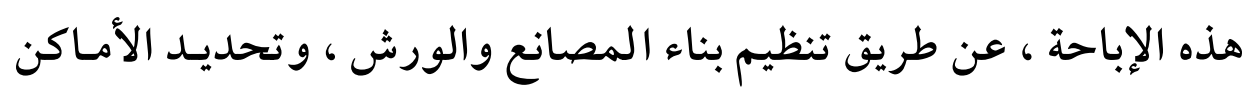

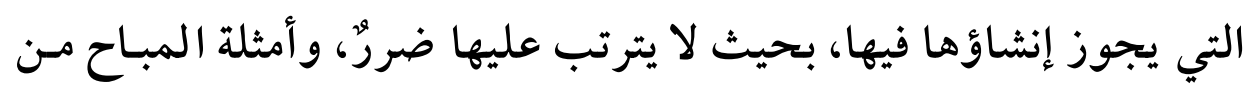
هذا النوع كثيرة. 


$$
\begin{aligned}
& \text { الفصل الثاني } \\
& \text { تقييد المريات السياسية } \\
& \text { ويشتمل على ثلاثة مباحث: } \\
& \text { المبحث الأول : تقييد حرية التجنس. } \\
& \text { المبحث الثاني: تقتييد حرية المشاركة السياسية. } \\
& \text { المبحث الثالث: تقييل حرية التقبير عن الرأي. }
\end{aligned}
$$


(7or)

سلطة ولي الأمر في تقييل الحريات السياسية للصصلحة العامة

\section{المبحث الأول}

تقييد حرية التجنس

\section{تهميلد:}

الجنسية مصطلح سياسي جديــ لم يستعمله الفقهاء القـدامى، وإن كانـت

حقيقة الجنسية في الشريعة الإسلامية ومعناها وارد في كتب الفقه الإسـلامي

مـن خـلال التعبـير بالرعيـة أو أهـل الــدار أو دار الإسـلام أو التبعيـة. وتقـوم

الجنسية في الشريعة الإسلامية على أساس الدار، أو بتعبير آخـر على أسـاس

الإسلام ومسالمته، والتزام أحكامه أو الكفر به، فأهل دار الإسلام لهـم جنسية

واحدة، سواء كانوا مسلمين أو ذميين (').

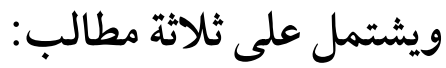

\section{الاطلب الأول \\ تعريف التجنس}

أولاً: تعريف الجنسية:

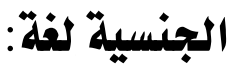

مشتقة من الجنس ، وهو: الضرب من كلّ شيءٍ، والجمع ( أَجْنَاسٌ ) وهـو

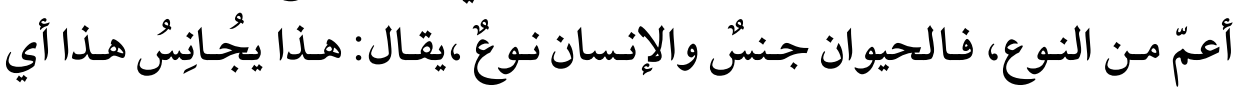

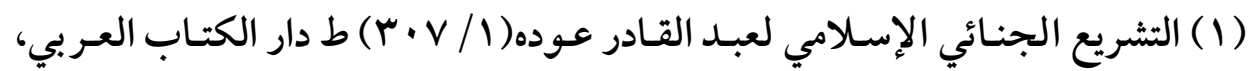


يشاكله، والجنسية هي: الصفة التي تلحق بالشخص من جهة انتسابه لشعبٍ

لما كان مصطلح الجنسية مصطلح حديث لم يتناوله الفقهاء القـدامى في

كتبهم ، وبالتالي ليس له تعريفٌ عندهم ، لذا سأذكر التعريف القانوني له. له.

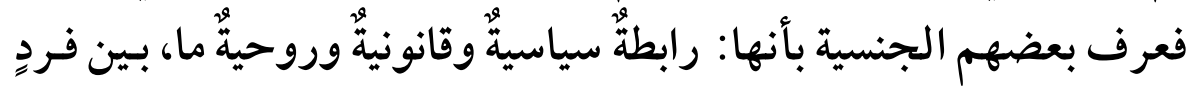

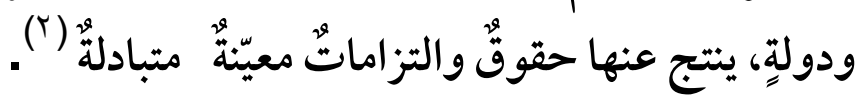

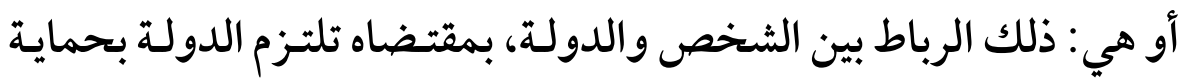

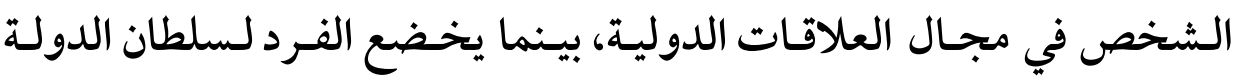

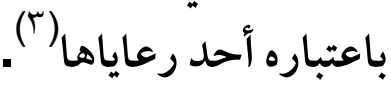

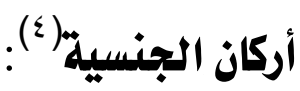

إذا كانـت الجنسية رابطـة سياسـية وقانونيـة بـين الفـرد والدولـة، ويترتـب عليها حقوق وواجبات ، فإن هذا الكيان له ثلاثة أركان:

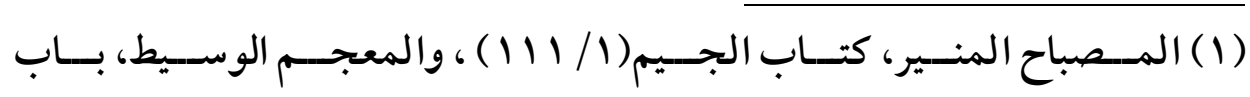

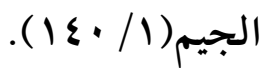

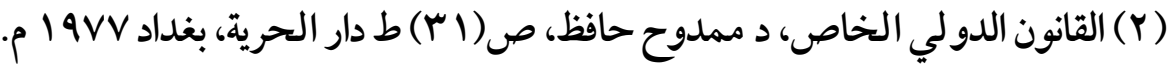

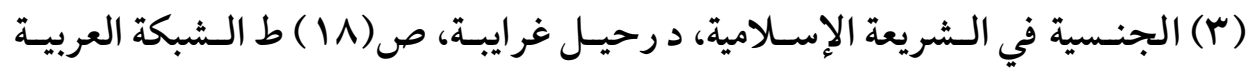

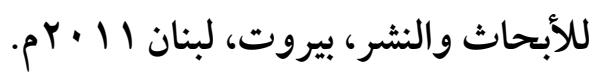

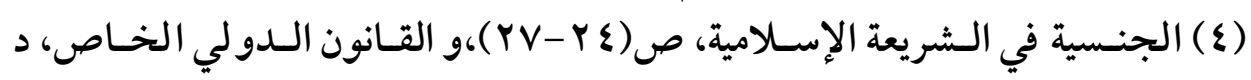

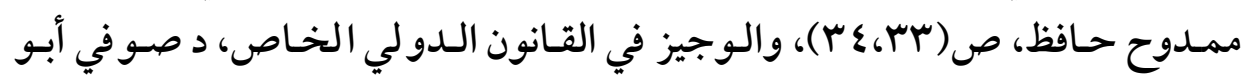

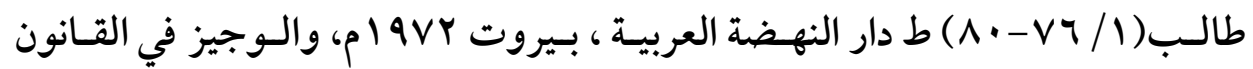

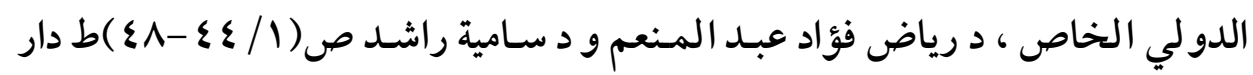

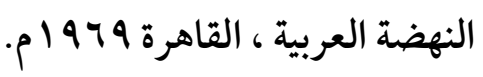


الدولة وحدها هي التي تتولى منح الجنسية حسب مـا تـر اه من المصلحة،

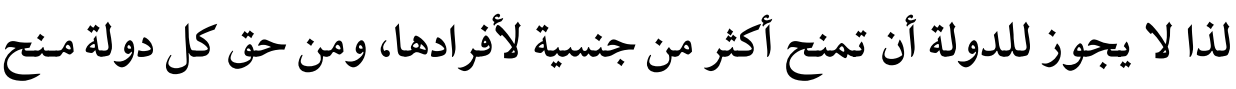

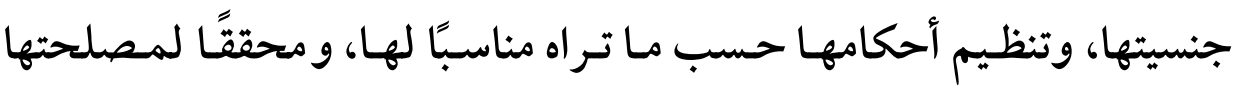
دون أيّ تـدخّلٍ مـن غيرهـا، نظـرًا لاسـتقلالها التـام، وسـيادتها عـلى شـعبها وأرضها .

\section{الركن الثاني : الثرد الذي تثبت لله الجنسية:}

إذا كانت الجنسية نظامًا سياسيًا وقانونيًا يتحدد به ركن الثعب؛ فبإن الفرد

هـ الوحـدة في تكـوين الشعب، فـالفرد هـو الذذي يـصلح أن يكسون طرفًا في رابطة الجنسية.

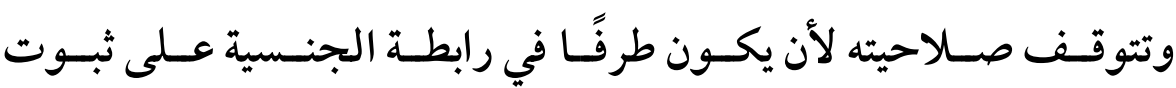
شخصيته القانونيـة، ويكفي في ثبـوت الشخـصية القانونيـة تـوافر الـصلاحية لكسب الحقوق وتحمل الالتزامات.

\section{الركن الثالث: الرابطة السياسية والقانونية بين الدولة والفرد:}

إذا كانت الجنسية رابطة سياسية وقانونية بين الفـرد والدولة مرتكرة على اعتبارات قانونية وسياسية واجتماعية، فإنه ينتج مـن ذلك حقوق والتزامـات على كل طرف، فمـن يحصل عـلى الجنسية يحصل على صفة المواطنة،

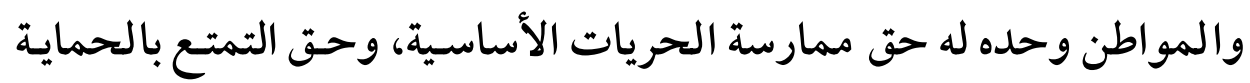
الدبلوماسية لشخصه وأمواله في حالة وجوده في دولة أجنبية، كما أنه يتحمل 
(700)

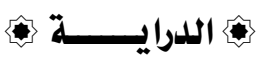

بعض التكاليف كالخدمة العسكرية، والالتزامات المالية، وإطاعة القوانين

$$
\text { والأوامر الصادرة من الدولة. }
$$

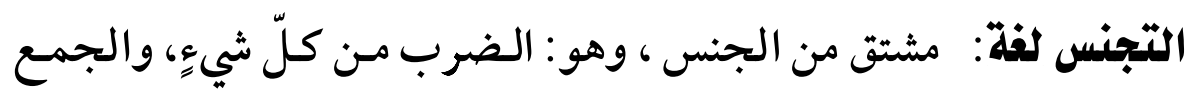

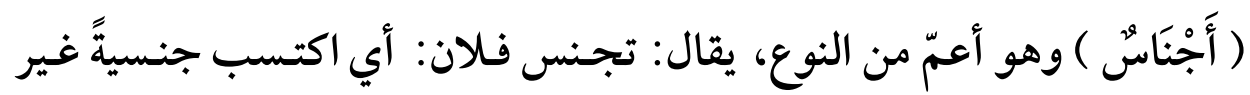

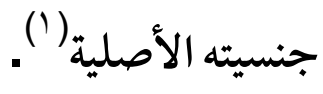

واصطلاحًا:

طريـق لكسب الجنسية بمنحهـا مـن الدولـة، حسب تقـديرها المطلـق،

للأجنبي الذي يطلبها، بعد استيفاء الشروط التي يتطلبها القانون (؟).

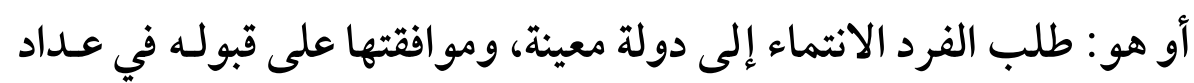

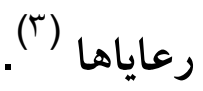

فــالتجنس عمــل إرادي يــم بموافقــة إرادتي الدولــة والأجنبـي طالـبـ

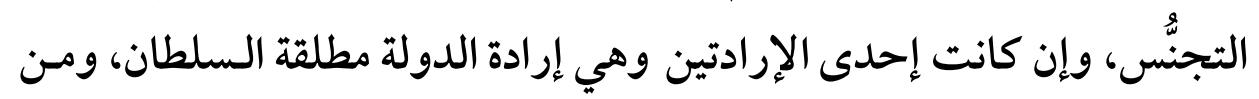

هنا تتضح خصائص التجنس وهي:

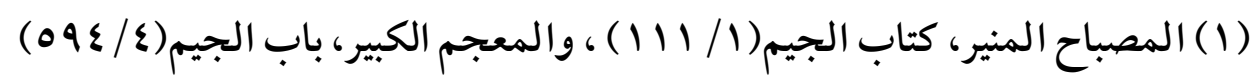

مجمع اللغة العربية.

(Y) التجنس، د عز الدين عبد الله ( / / ) مجلة العلوم القانونية والاقتصادية، جامعـة

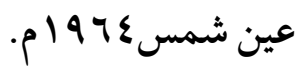

(r) القانون الدولي الخاص، د هشام علي صـادق، ص(70) ط دار الفكر الجامعي،

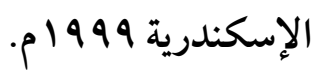


(707)

سلطة ولي الأمر في تقييل الحريات السياسية للمصلحة العافة

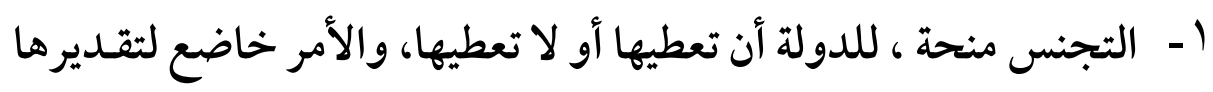

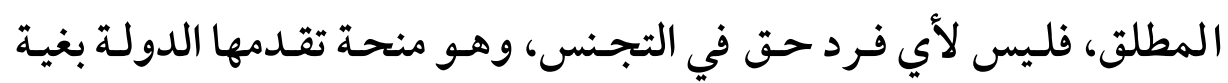

تحقيق مصلحتها في الغالب، قاصدة زيادة ثروتها السكانية كيفًا أو كمًا.

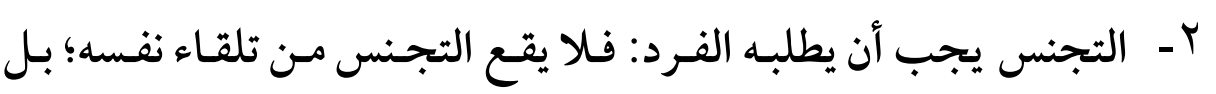

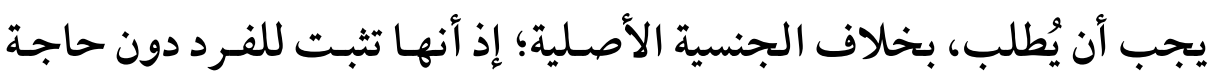

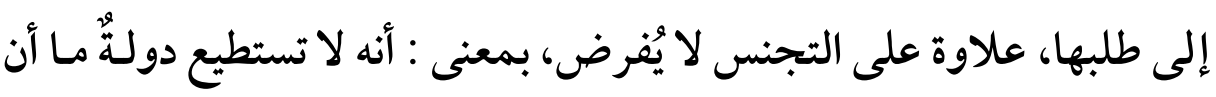
تفرض جنسيتها على فردٍ عن طريق التجنس دون رضاه ( ') الإطلب الثاني

\section{أحكام تتعلق بالتجنس}

حكم تجنس المسلم بجنسية دولة غير إسلامية للضرورة:

لا خـلاف بـين الفقهـاء في إباحـة التجــس بجنـسية دولـة غـير إسـلامية

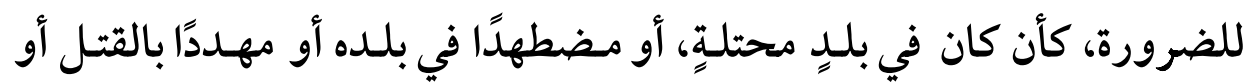

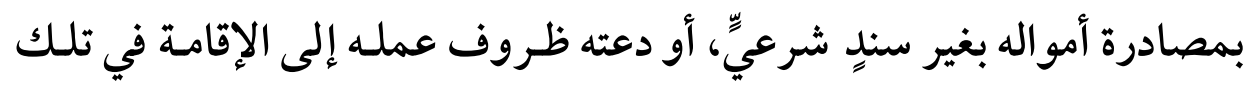

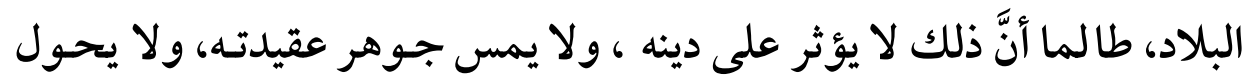

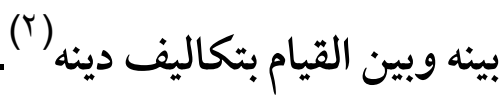

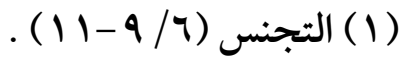

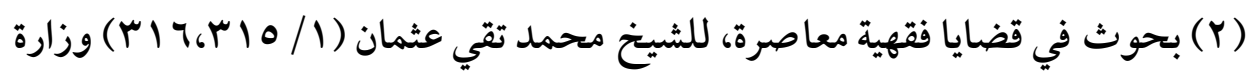

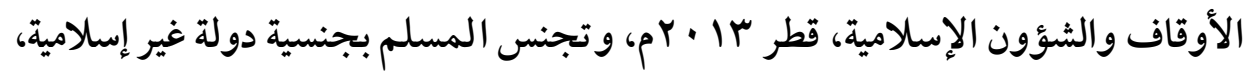

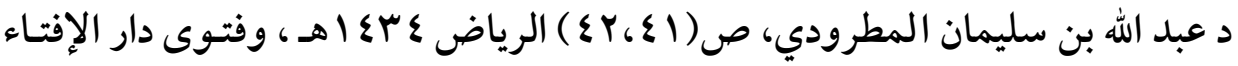

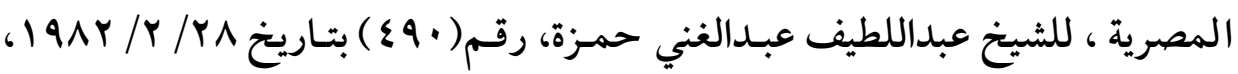




\section{واستدلوا على ذلك بعدة أدلةٍ ، منها:}

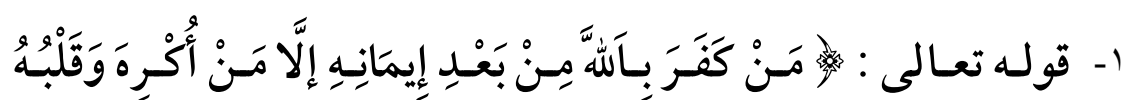

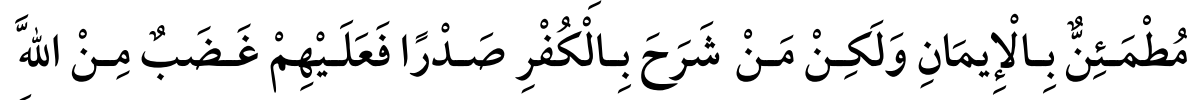

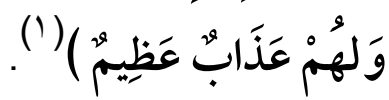

\section{وجه الدلالة:}

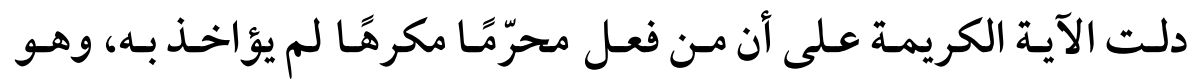

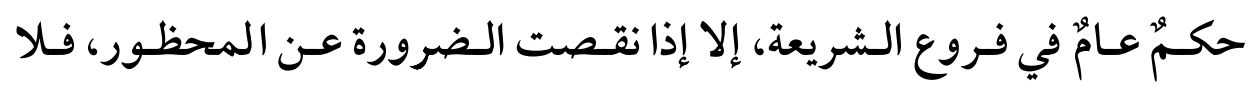

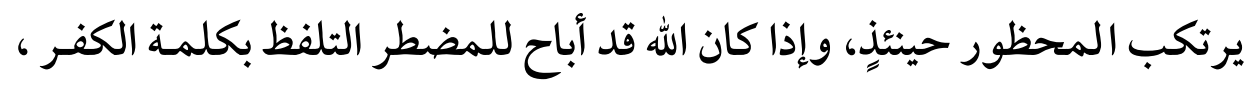
فكذا يباح ما دونها كالتجنس بججنسية دولة غير إسلامية في حالة الاضطر ار.

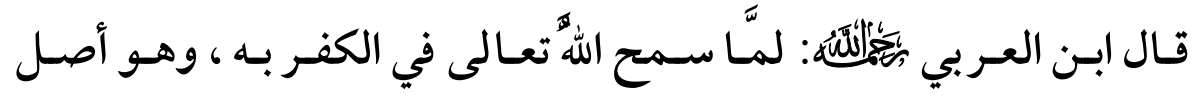

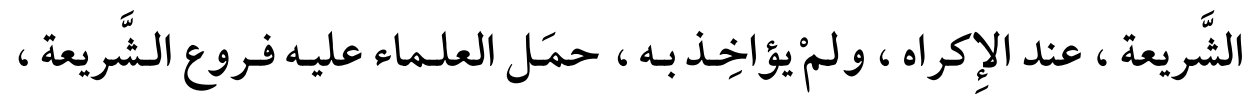

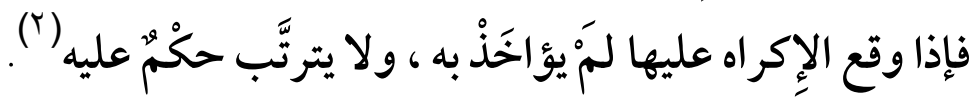

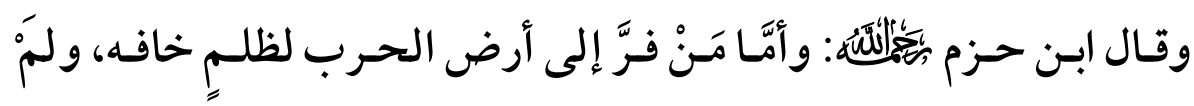

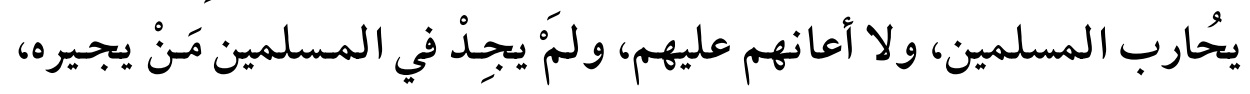

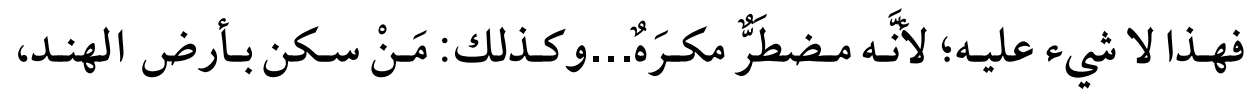

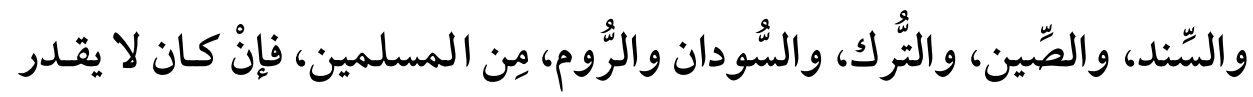

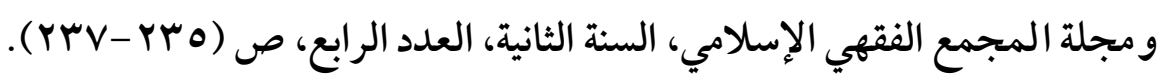
(1) سورة النحل، الآية (1 · (1).

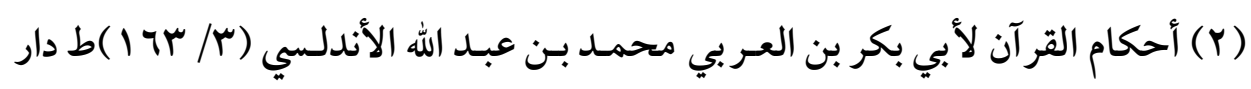

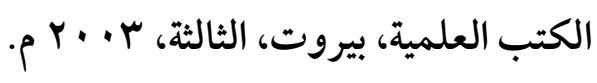


$(701)$

سلطة ولي الأمر في تقييد الحريات السياسية للمصلحة العامة

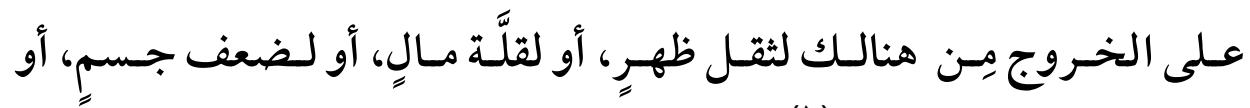
لامتناع طريقِ، فهو معذورو (')

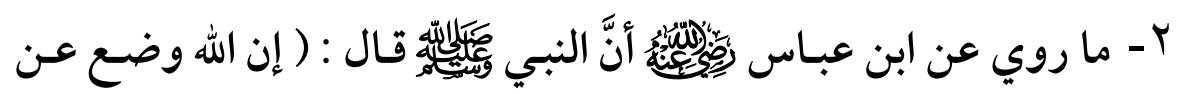

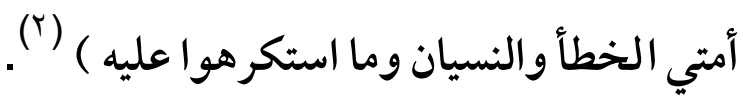

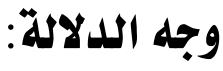

دل الحديث على أن المسلم إذا أكره على فعلٍ محرَّم فإنهـ لا يترتـب عليـه حكمّ ، ولا يؤاخذ به؛ لأن الإكر اه يرفـع المؤاخـذة ، والمتجــس بجنسية دولـة غير إسلامية للضرورة يشبه المكرَه فرُفِع عنه الحرج. "- اسـتدلوا بقاعـدة : " الـضرورات تبـيح المحظوررات " وهـي مـن القواعد الكلية التي تدل على أن حالات الاضطر ار تبيح ارتكاب المحظور

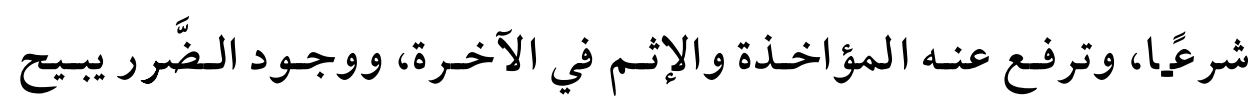

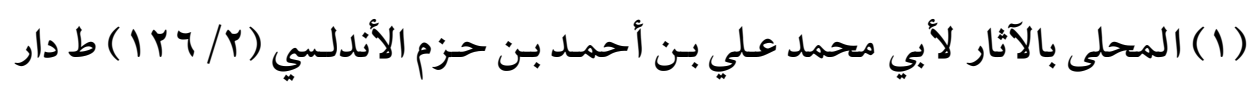

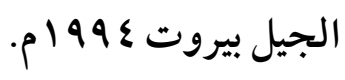

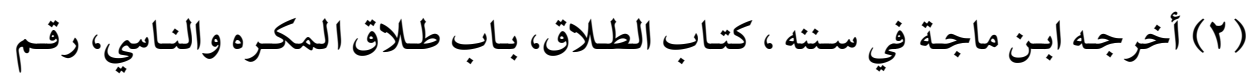

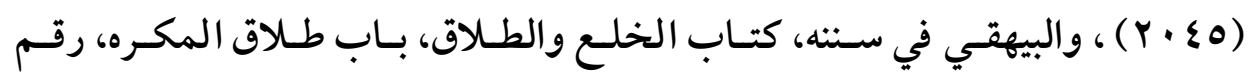

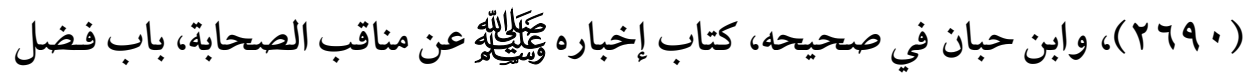
الأمة، رقم(YY) حبان والحاكم وقال صحيح على شرط الشَّيخين. تحفـة المحتـاج إلى أدلة المنهاج

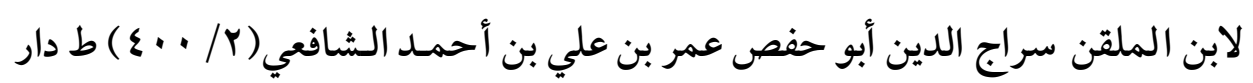

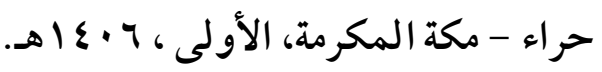


(709)

ارتكاب المحظور، أي المحرَّم، بشرط كون ارتكاب المحظور أخفِّ مـن

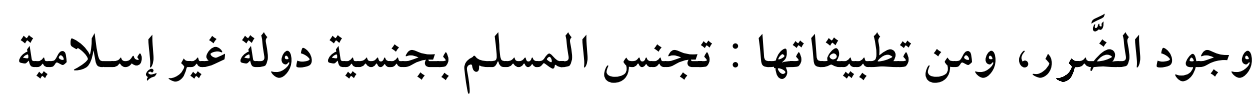

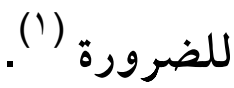

\section{حكم تجنس المسلم بجنسية دولة غير إسلامية لفير الضرورة:}

اختلف الفقهاء المعاصرون في حكم ذلك على ثلاثة أقوال:

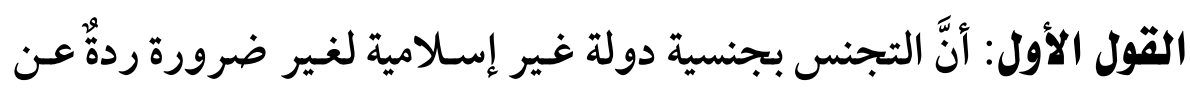

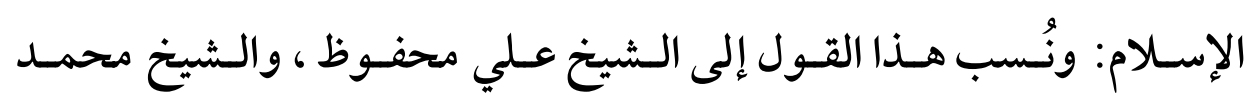
عبدالعظيم الزرقاني والشيخ محمد شاكر والشيخ يوسف الدجوي المالكي

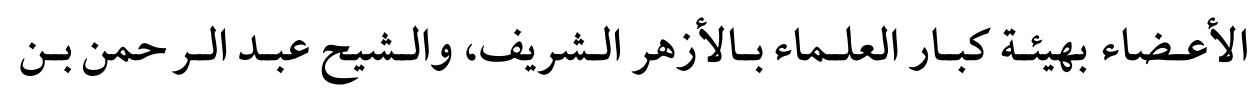
باديس الجزائري وغيرهم (r) .

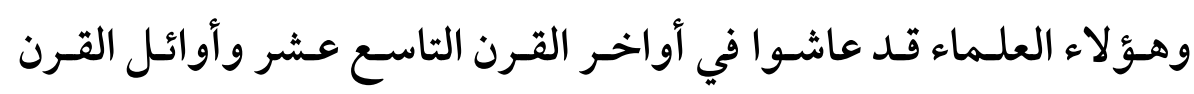
العشرين، حيـث عاشـوا الأحـداث التي حصلت للعـالم الإسـلامي مسن قِبَّل

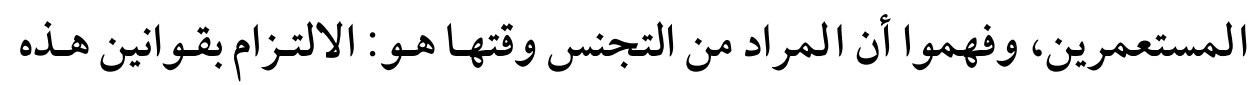

(1) الأشباه والنظائر للإمام تاج الدين السبكي(1/ V Vه) ط دار الكتب العلمية، الأولى

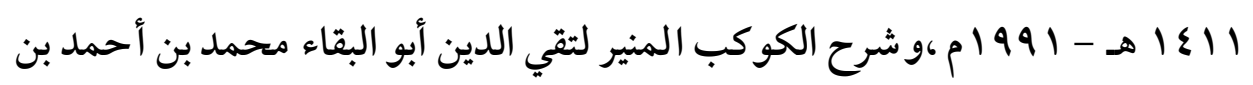

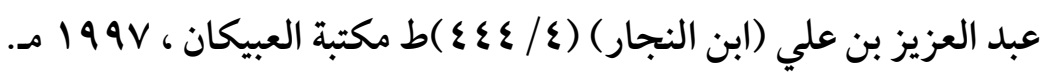

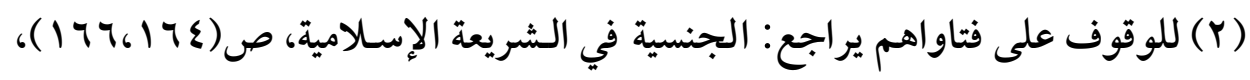
وحكم التجنس بجنسية دولة غير إسلامية للشيخ محمد بن عبدالله بن سبيل، ص(VI)

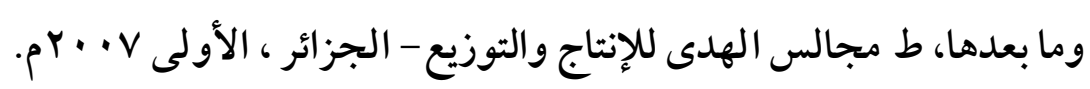


(77.)

سلطة ولبي الأمر في تقييد العريات السياسية للصصلحة العامة

الدول، بدل أحكام الشريعة، حتى في الأحوال الشخصية، كالنكاح والطلاق والمواريث، والوقوف في صفوفها عند محاربتها، ولو لدولة إسلامية (1)

\section{واستلدلوا على ذلك بعلدة أدلة، منها:}

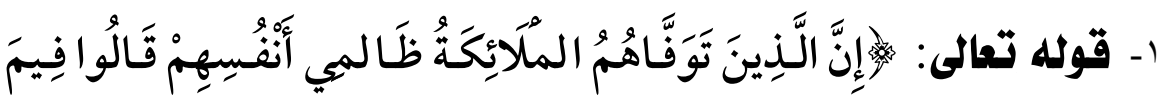

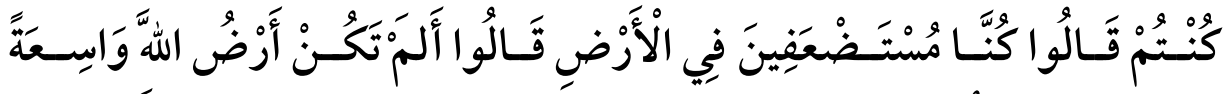

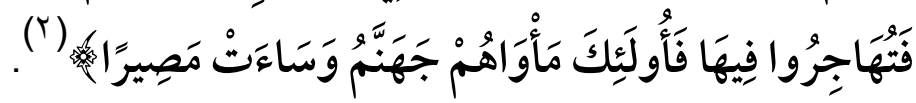

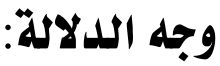

دلت الآية على تحريم الإقامة في بلاد الكفـر، وكفـر مـن اختـار ذلك،

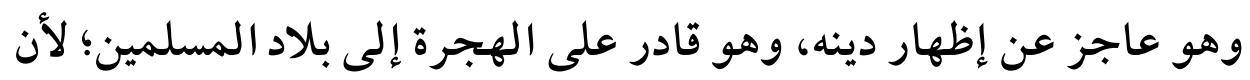

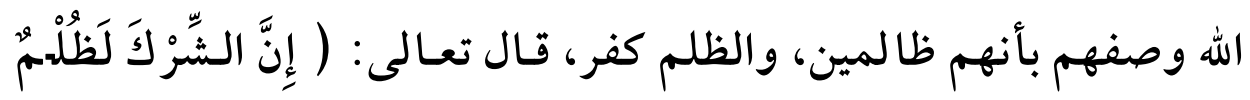

عَظِيممْ(r)

فيوم نزلت هذه الآية كان من أسلم ولم يهاجر، فهو كافر حتى يهاجر، إلا

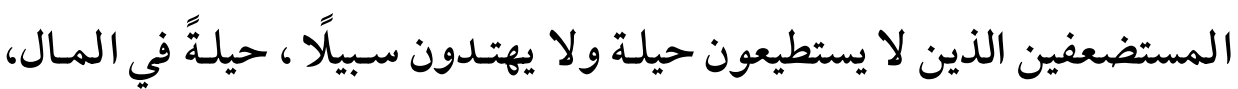

و"السبيل": الطريق (؟).

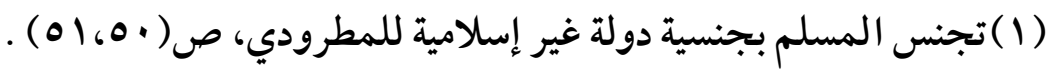

$$
\begin{aligned}
& \text { (Y) سورة النساء، الآية (qV). } \\
& \text { (r) سورة لقمان، من الآية (r/). }
\end{aligned}
$$

( ) جامع البيان في تأويل القر آن لأبي جعفر الطبري (9 / ؟ + 1) ط مؤسسة الرسـالة،

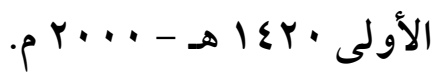


(771)

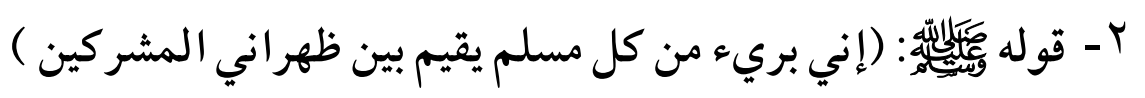

قالوا : يا رسول الله ولم ؟ قال : ( لا تراءى ناراهما ) ( ').

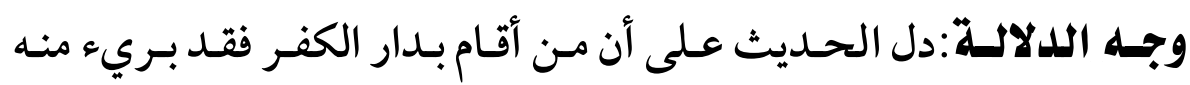

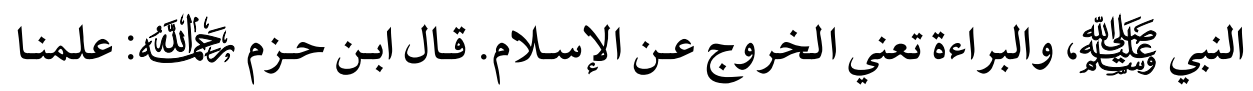

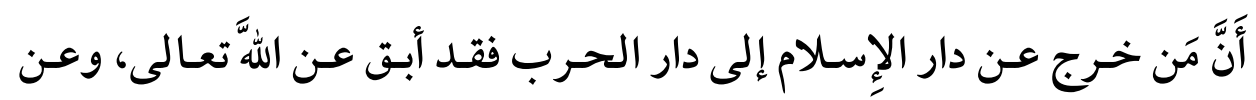

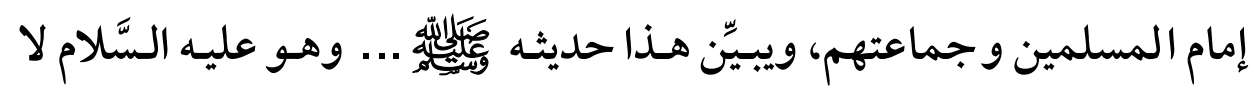

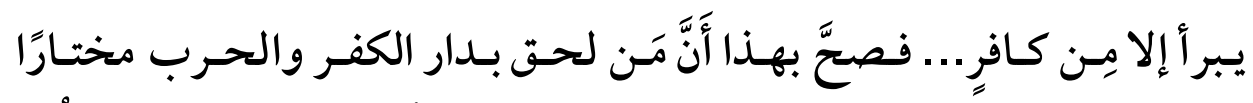
محاربًا لمن يليه مِن المسلمين، فهو بهذا الفعل مرتدّّل له أحكام المرتدِّ كلُّهـا

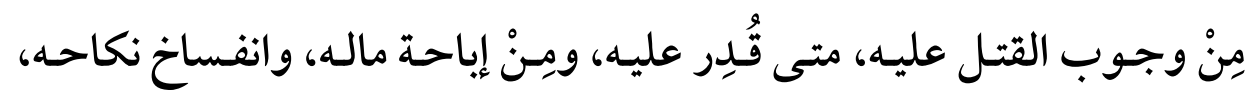

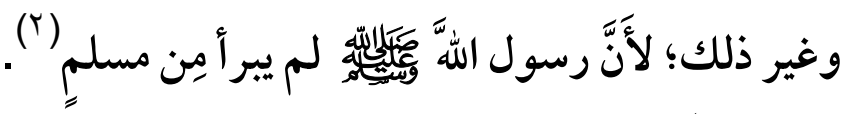

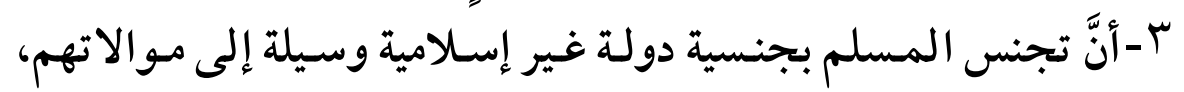
وموافقتهم على ما هم عليه مـن الكفر والباطل، ومـوالاة الكفـار ومـوافقتهم

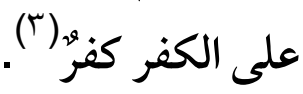

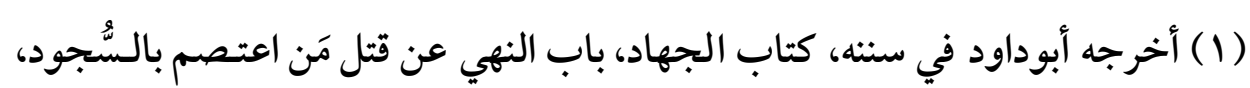

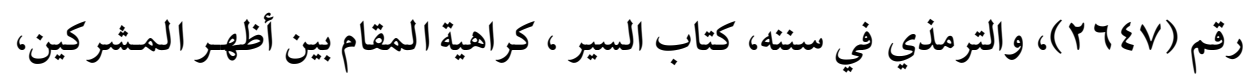

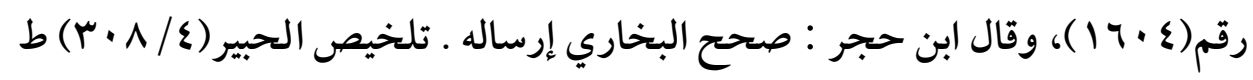

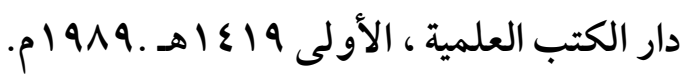

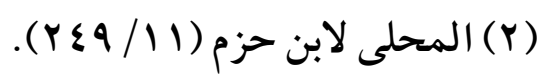

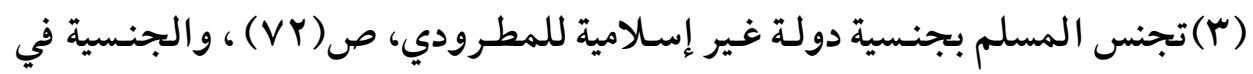

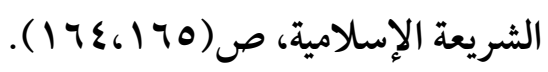


(7Tr)

القــول الثـاني: أن الأصـل في التجـسـ بجنسية دولـة غـير إسـلامية لغسير

ضرورة حـرامٌ شرعًا، إلا إذا كـان مـن أجــل نسشر الإسـلام ، أو الـدفاع عـن

المسلمين فيجوز التجنس لمن توفرت لديه الشروط والضوابط الشرعية، مـن

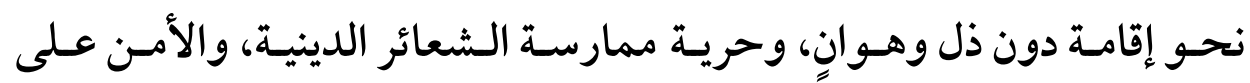

الدين والنفس و الأهل والمال من الاعتداء، والاحتراز من الفتنة في الدين.

ونُسب هذا القـول إلى الشيخ محمـد بـن عبـدالله بـن سـبيل إمـام وخطيـب

$$
\text { المسجد الحرام، }
$$

والـشيخ محمــد تقي العـثماني، والـشيخ محمـد الـشاذلي النيفـر عـضو

المجمع الفقهي (1)

واستدلوا على ذلك بعدة أدلة، منها:

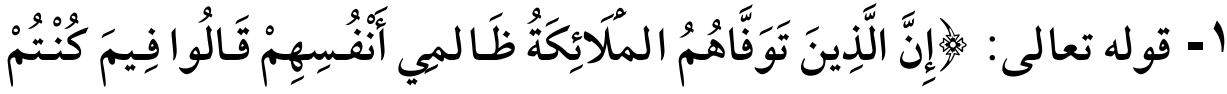

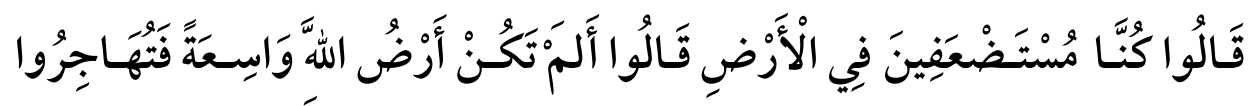

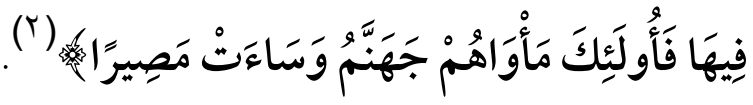

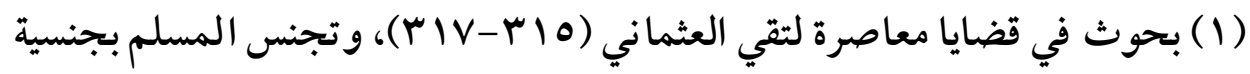
دولة غير إسلامية للمطرودي، ص(م) (OY.Or)، والتجنس بجنسية غير إسلامية للشيخ

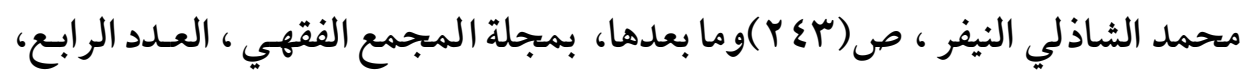
وحكم التجنس للشيخ محمد بن سبيل، ص ( • (9) وما بعدها .

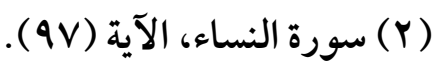




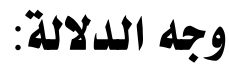

دلت الآية على تحريم الإقامة في بلاد الكفـر لمـن قـدر عـلى الانتقـال

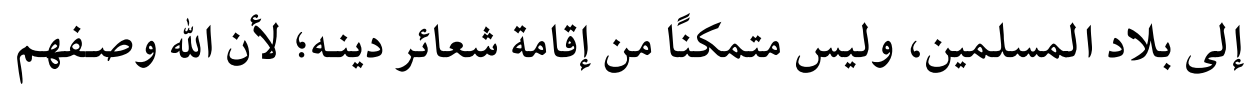

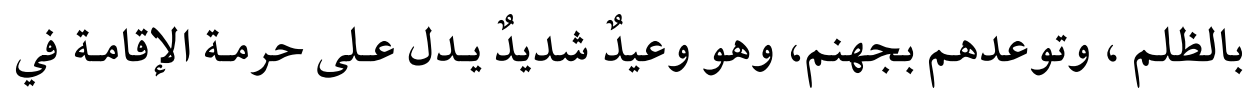

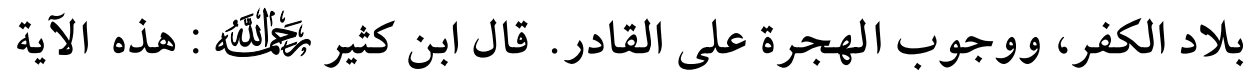

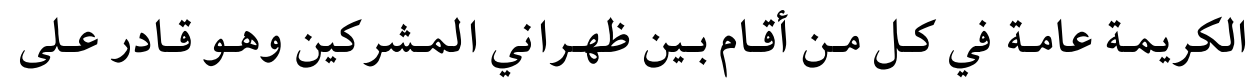

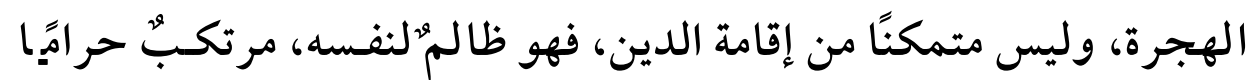

بالإجماع، وبنص هذه الآية (')

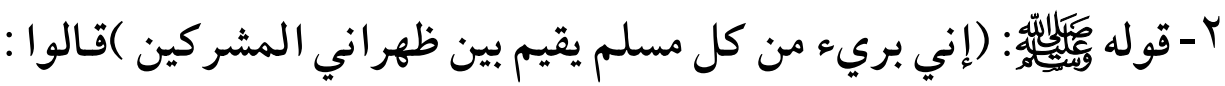

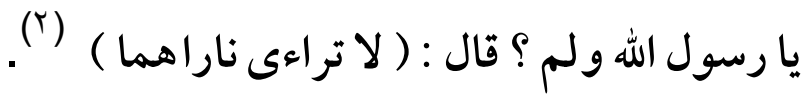

\section{وجه الدلالة:}

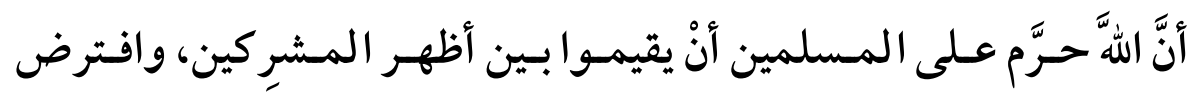

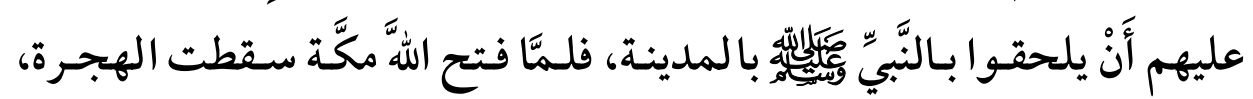

$$
\text { وبقي تحريم المقام بين أظهر المشر كِين ("). }
$$

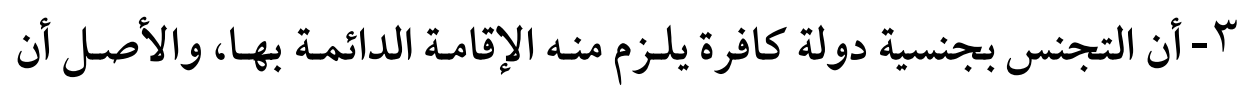

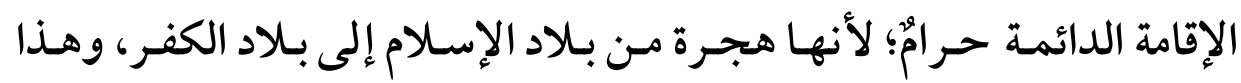

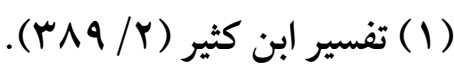

$$
\begin{aligned}
& \text { (Y) سبق تخريجه. }
\end{aligned}
$$

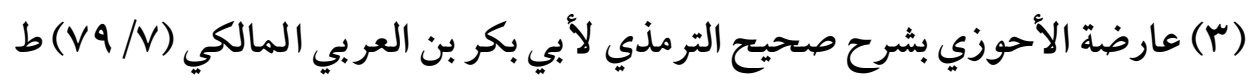
دار الكتب العلمية بيروت. 
(7าร)

سلطة ولي الأمر في تقييد العريات السياسية للمصلحة العامة

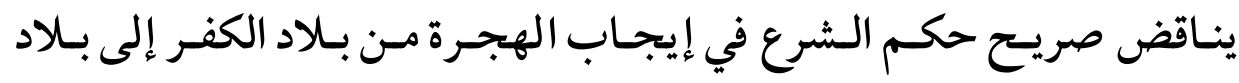

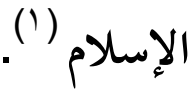

واستدلوا على جواز التجـس لأجـل الـدعوة إلى الإسـلام ونشـره والدفاع

عنه وعن المسلمين والمطالبة بحقوقهم :

أن حصول المسلم على جنسية دولة غير إسـلامية قد تحققى مصلحة مـن

المصالح العليا للإسلام والمسلمين ؛ لأنه بذلك يتمتع بكامل حقوقهـ، ومنها

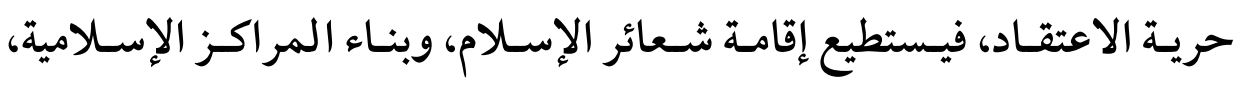

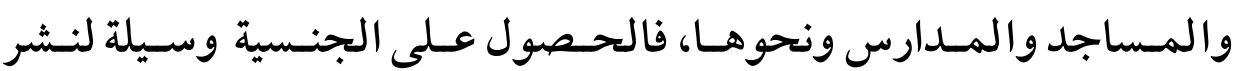
الإسلام والدعوة إلى الله.

القول الثالث: أن التجنس بجنسية دولة غير إسـلامية في هـذا العصر جـائزٌ

للقـادر عـلى إقامـة شـعائر الإسـلام، وذلـك بعـد وضـع الدسـاتير، ووضـوح الحقوق والواجبات عند منح الجنسية، ونُسب هـذا القول إلى الشيخ عبدالله

بن بيّه، والدكتور وهبه الزحيلي، واللواء عادل عفيفي (r)

(1) تجنس المسلم بجنسية دولة غير إسلامية للمطرودي، ص(V9).

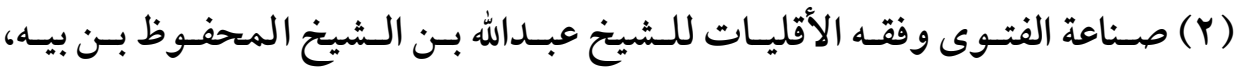

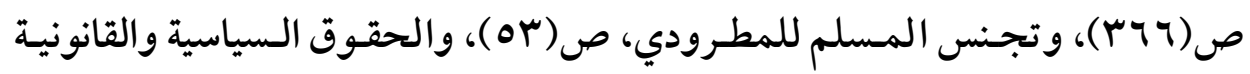

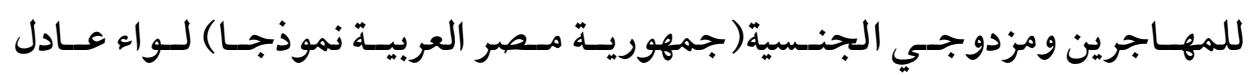

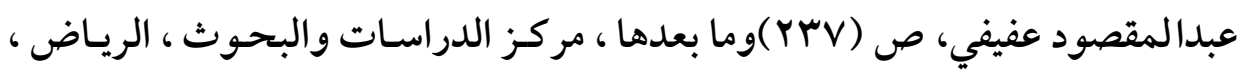

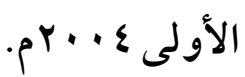


(770)

\section{واستلدلوا على ذلك بعدة أدلة، منها:}

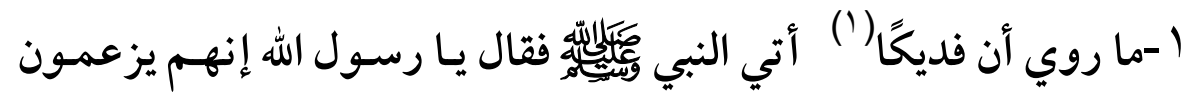

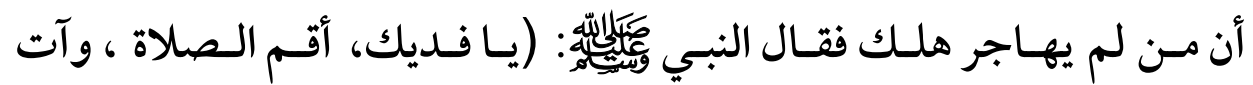

الزكاة ، واهجر السوء ، واسكن من أرض قومك حيث شئت) (؟).

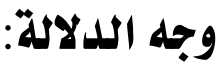

هذا الحديث تبيان الهجرة التي يدخل فيها من يـدخل فيها بعـد فتح مكَّة،

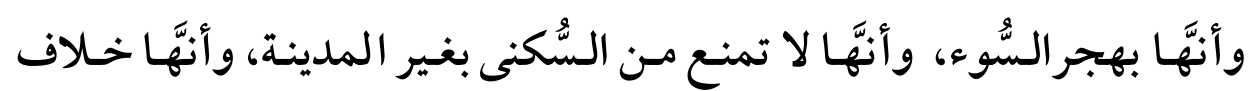

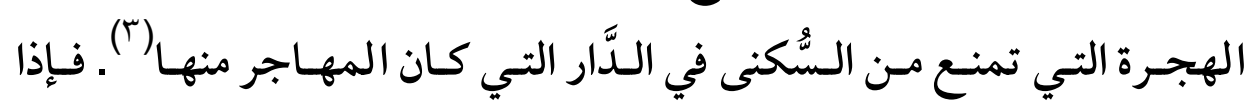

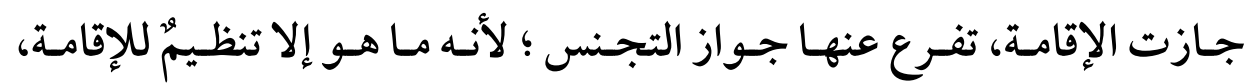
وحفظٌ للحقوق، وتسهيل للاستفادة من الخدمات العامة. r-أنّ في حصول المسلم على جنسية دولة غير إسلامية مصالح كلية، ومقاصد شرعية، تزيد بكثير على مـا فيه مـن مفاسـد، وعـدم تجـنس المسلم

(1) هو: فديك الزبيدي ويقال العقيلي، والد بشير بن فـديك، وقال البخـاري: فديك

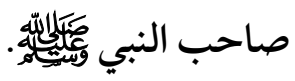

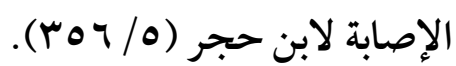

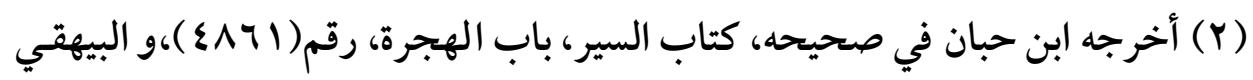

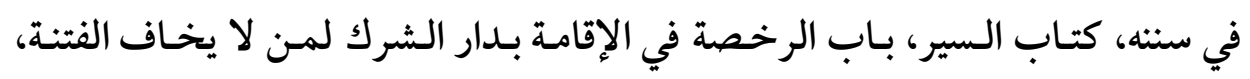

رقم(IVVVYr)

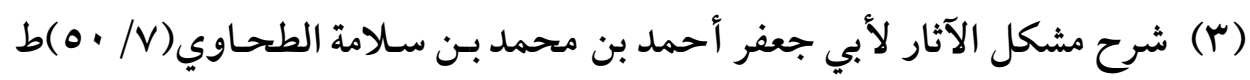

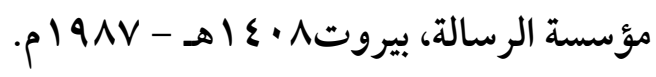


(7ร7)

بتلك الجنسية يمنعه من تحقيق تلك المصالح، فينبغي تقـديم مـا فيـه مصالح

راجحة، على ما فيه مفاسد مرجوحة (')

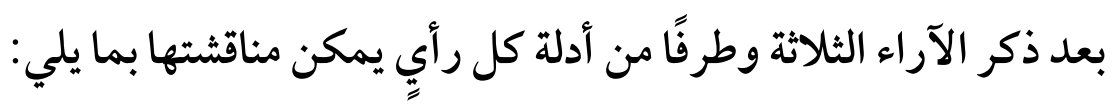

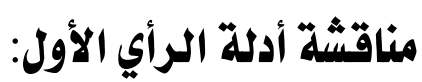

أولاً: بالنسبة لاستدلالهم بالآية الكريمة فيمكن مناقشته بأن المر اد بـالظلم في الآية المعصية العظيمة وليس الكفر ، ألم يقل الله تعالى : (وَالَّذِينَ آَتنُوا

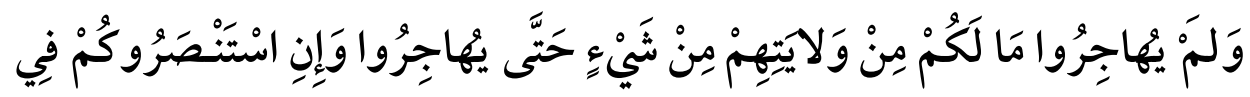

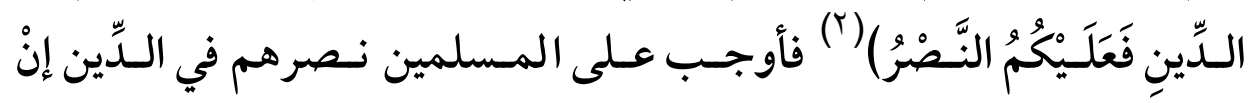
استنصروهم، وهذه حالةٌ تخالف حالة الكفَّار (َ). علاوة على أن هذه الآيـة ليست علمى عمومها في تحريم الإقامة في بـلاد

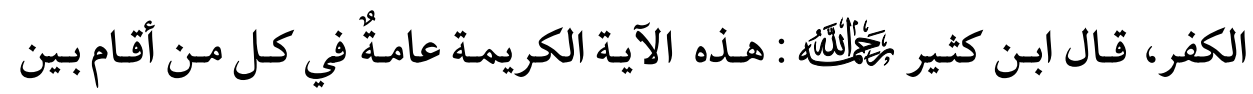

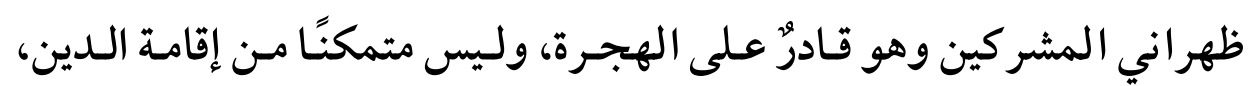

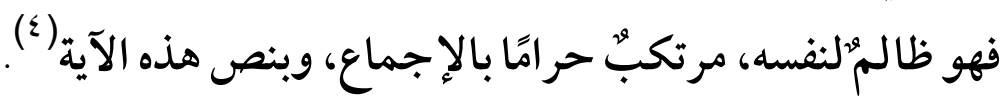

(1) الجنسية والتجنس و أحكامهما في الفقه الإسلامي، د سميح عواد، ص(YTV)

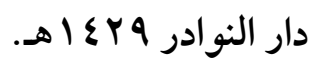

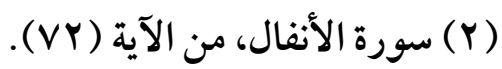

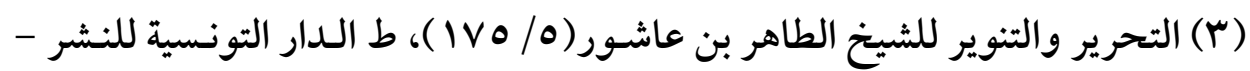
تونسع 1919 هـ. (19)

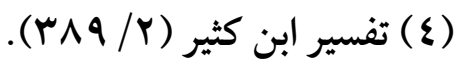


ثانياً: بالنسبة لاستدلالهم بالحديث فيمكن مناقشته بأنه حـديث مرسل ،

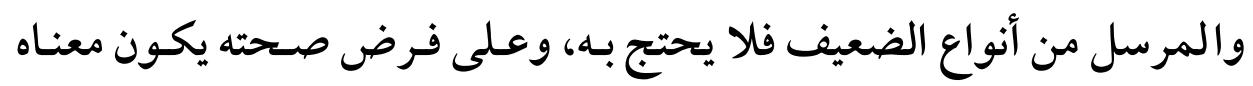

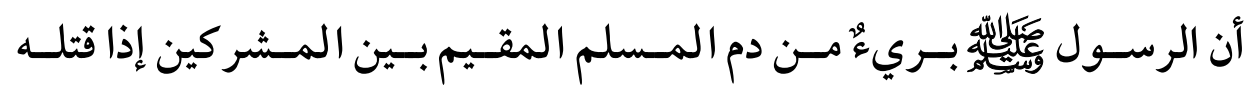
المسلمون على سبيل الخطأ؛ ويؤكد ذلك سبب ورود الحـديث، فعـن جريـر

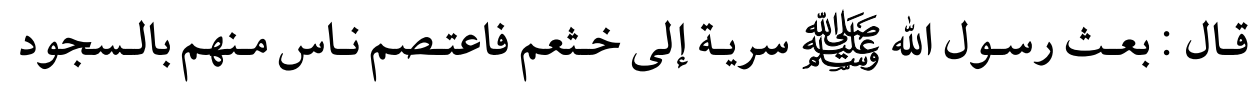

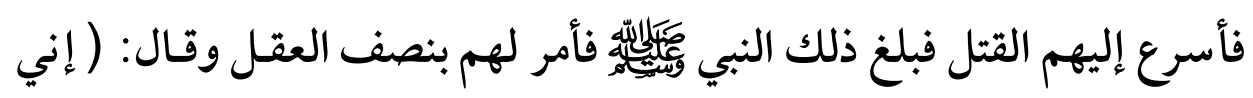

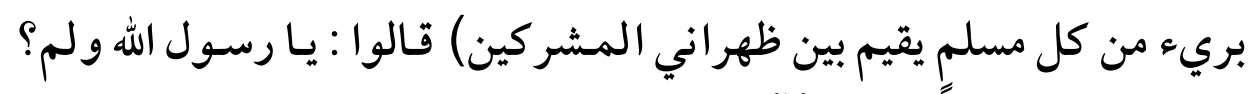

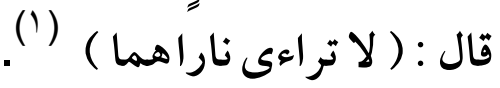

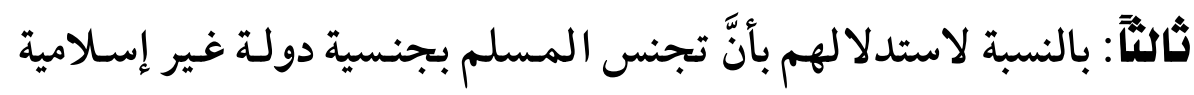

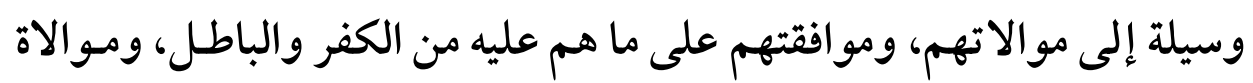

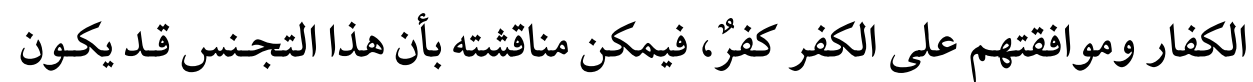

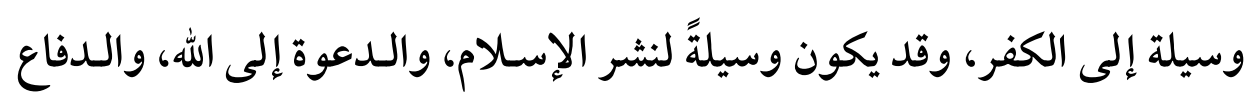
عن حقوق المسلمين و حمايتهم ، فيكون من أنواع الجهاد، فلا يصح الحكـم الإسم على جميع المتجنسين بذلك.

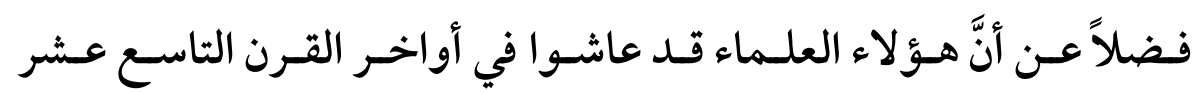

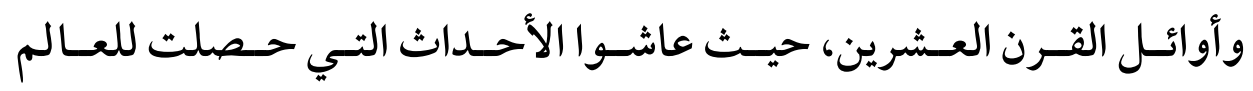

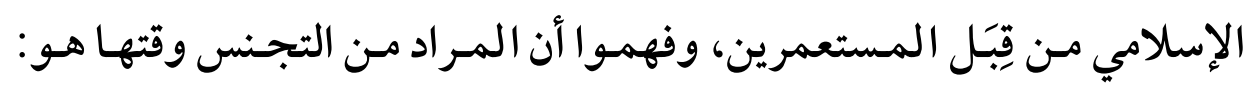

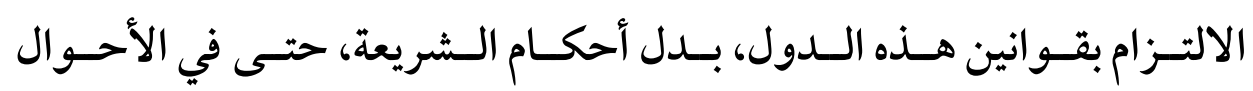


(774)

سلطة ولي الأمر في تقييل الحريات السياسية للصصلحة العامة

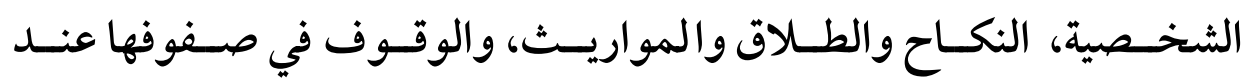

محاربتها، ولو لدولة إسلامية (')

مناقشة أدلة الرأي الثاني:

أولاً: بالنسبة لاستدلا لهم بالآيـة الكريمـة فيمكن مناقشته بأنه يستثنى مـن

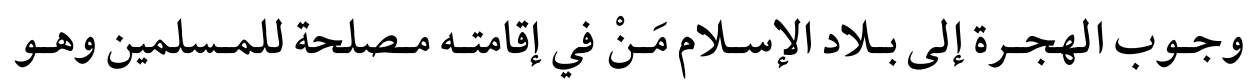

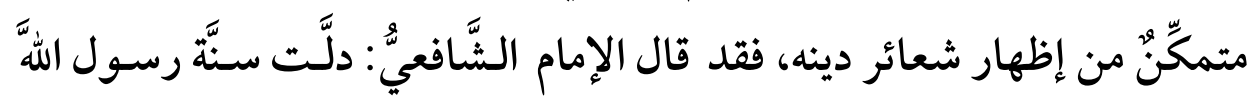

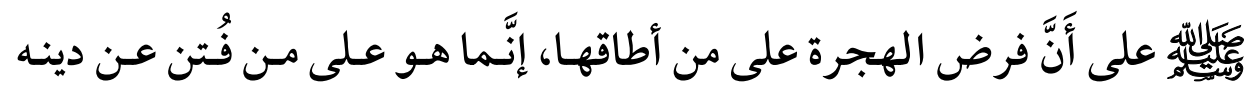

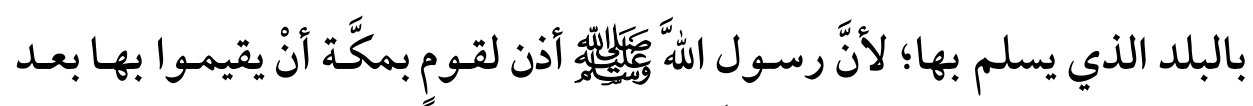

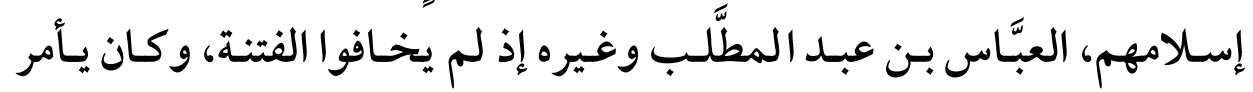

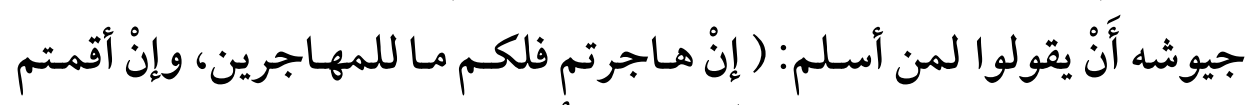

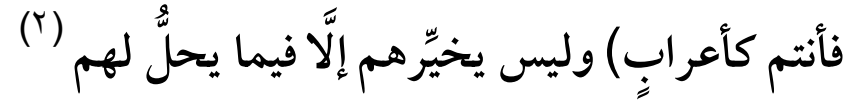
ثانياً: بالنسبة لاستدلا لهم بالحديث فقد سبقت مناقتشته في القول الأول.

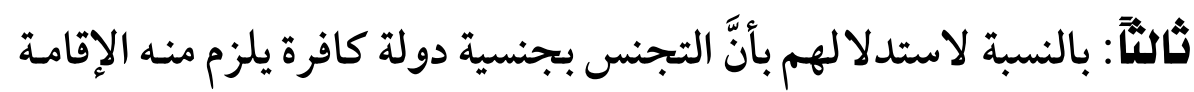

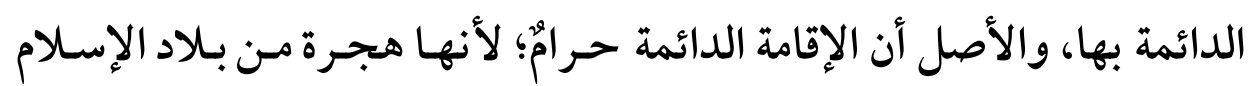
إلى بلاد الكفر، وهذا يناقض صريح حكم الشرع في إيجاب الهجرة من بـلاد

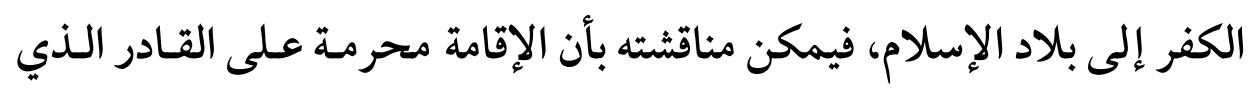

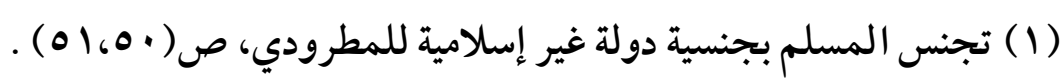

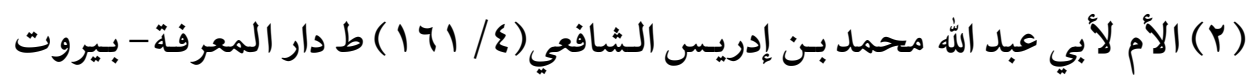


لا يأمن على دينه، وغير مـتمكِّنُ مـن إظهار شـعائره، أمـا مـن يأمن على دينه ويتمكٌٌِّ من إظهار شعائره ، فلا تحرم عليه الإقامة، ولا تجب علئ عليه الهجرة.

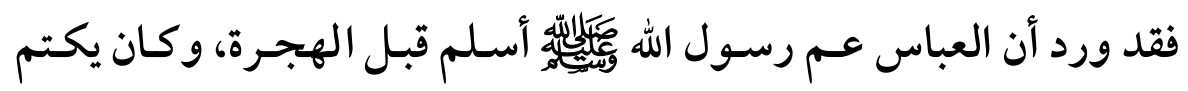

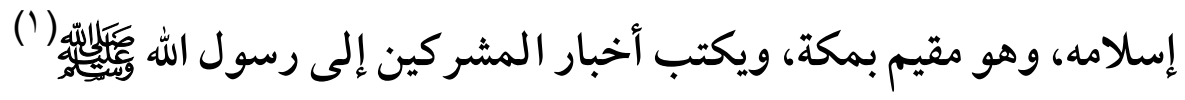
مناقشة أدلة الرأي الثالث:

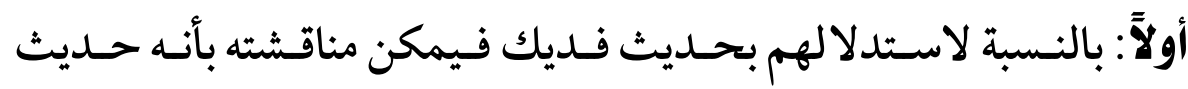
مرسل ، والمرسل من أنواع الضعيف فلا يحتج به (؟).

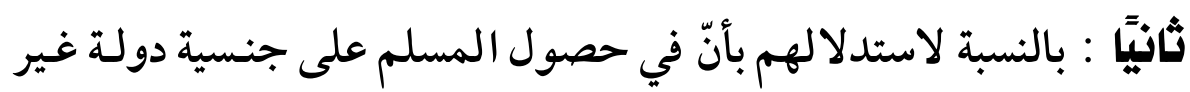

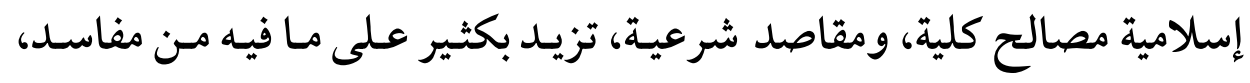
وعدم تجنس المسلم بتلك الجنسية يمنعه من تحقيق تلك المصالح، فينبغي تقديم ما فيه مصالح راجحة، على ما فيه مفاسد مرجوحة، فيمكن مناقشته بأن قاعدة جلب المصالح ودرء المفاسـد تحتـاج في تطبيقها إلى موازنةِ دقيقدِة.

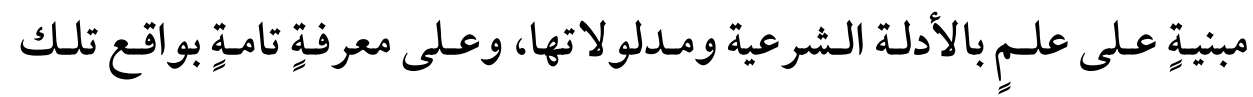

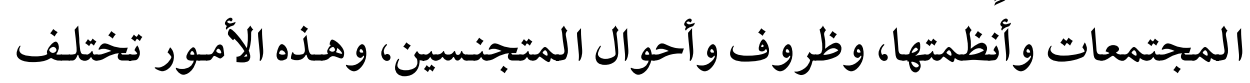

(1) حاشـية الجمل عـلى المـنهج لشيخ الإسـلام زكريـا الأنصاري للشيخ سـليمان

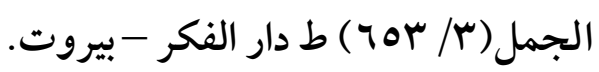

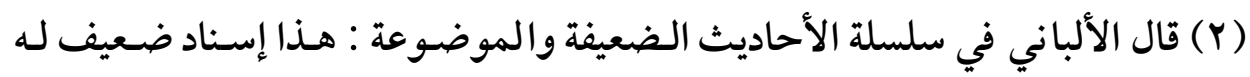

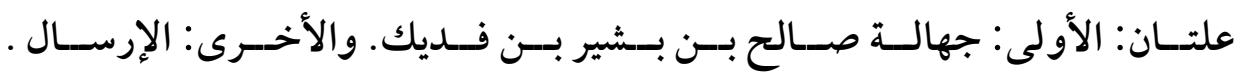

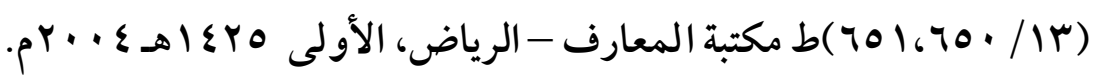


(TV・)

سلطة ولي الأمر في تقييل الحريات السياسية للمصلحة العامة

من دولةٍ للأخرى، ومن زمنٍ لآخر، ومن شـخصٍ لآخـر ، ممـا يجعـل الحكـم بالجواز المطلق مخالفًا لهذه القاعدة.

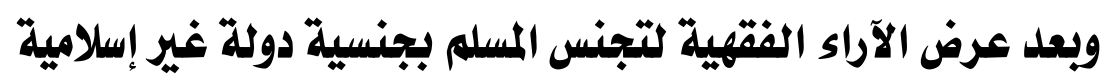
وأدلتها ومناقشتها تبيز الآتي:

ا - أن مسألة التجـنس نازلة فقهيـة معـاصرة، مبنيـة على السياسة الشرعية، والاجتهاد الفقهي. r - أنّ التجـنس قـد يكـون واجبًا؛ إذا كـان وسـيلةً لتحقيـق مـصلحةٍ راجحـةٍ كالدعوة إلى الله، ونشر الإسلام، و حماية المسلمين ، وضمان حقوقهم.

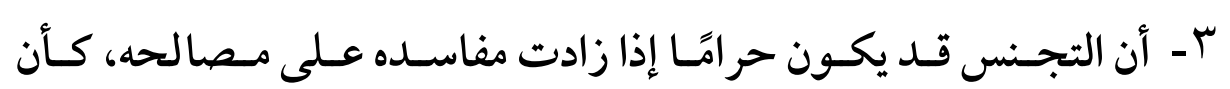
انغمـس في عـاداتهم وتقاليـدهم، وعـايش الفحـش والمنكـرات ، وتعـرض للفتنة في الدين. ك - أن التجـنس قـد يكـون جـائزًا ، إذا كـان لحفـظ ضرورة مـن الـضرورات الخمس (حفظ الدين، والنفس، والعقل، والعرض، والمال). 0 - أن التجنس قد يكون ردةً، إذا كانت مفاخرةً بأهـل هـذه الجنسية، ورضًا بدينهم، وحبًا لثرعهم، وموالاةً ومناصرةً لأهله ضد المسلمين. 7ـ أنّ في تجنس المسلم بجنسية دولـة غير إسـلامية ثأثيرٌٌ على القـرارات والمواقف العالمية، فهذه البلاد هي التي تقود العالم، وتسيطر عـلى سياسته و اقتـصاده، فينبغـي عـلى المسلمين أن يكـون لهـم حسضور مـؤثر في تلـك 
V- وجود المتجنسين في تلك البلاد يسهل توضسيح حقيقة الإسلام ،ونشر

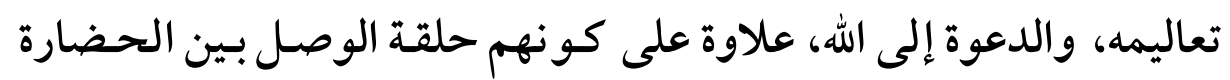
الإسلامية والحضارة الغربية .

\section{المطلب الثالث}

\section{سلطة ولي الأهر في تقييد حرية التجنس}

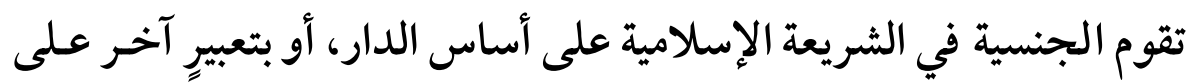

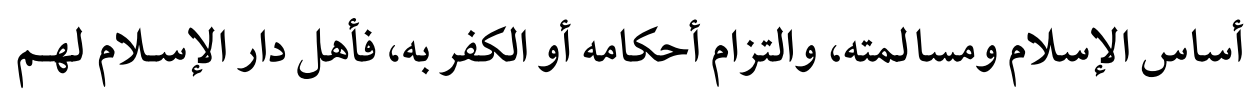

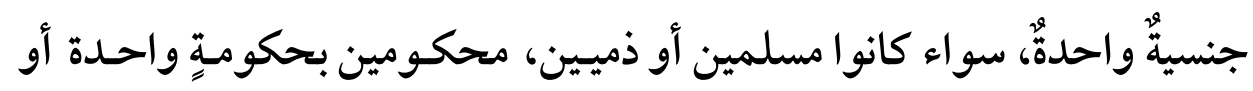

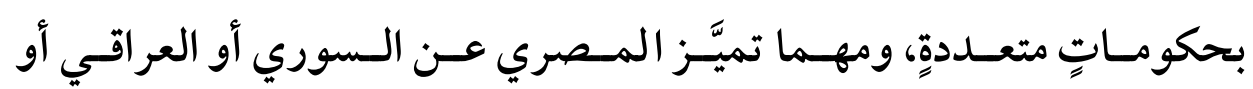

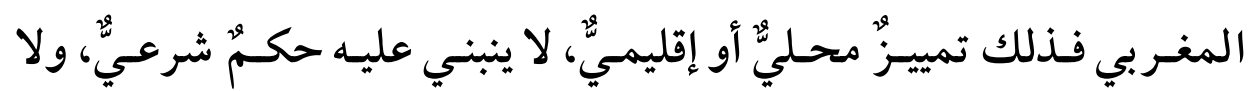

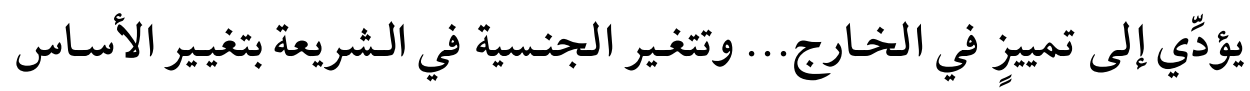

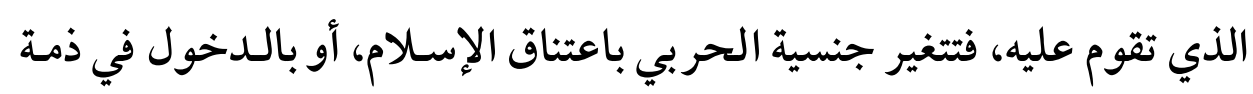

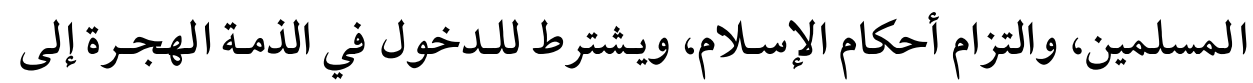
دار الإسهام (1) والجنسية ترتبط ارتباطًا وثيقًا بكيـان الدولة، فتحـدد ركـن الشعب فيها،

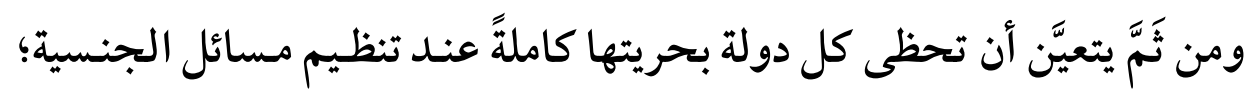

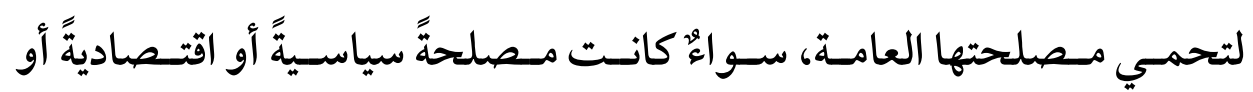

$$
\text { اجتماعيةً (r) التحمي }
$$

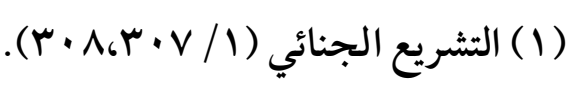

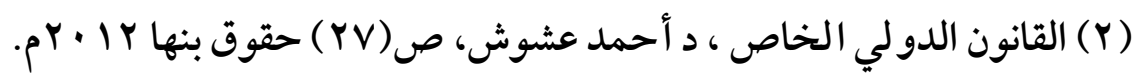


ولما كانت الجنسية رابطةً سياسـيةً وقانونيـةً بـين فردٍٍ ودولةٍ توجـبـ عليـه

الـو لاء لهـا، وهـي إذ تخلـق الجنـسية بإر ادتهـا وحـدها، تحــدد شروط مـنح الجنــسية، و شروط كـــبها، وشروط فقــدها حـــب الوضــع الـذي تــــام

مستكمالًً لعناصر وجودها (')

وحرية التجـنس مقيـدة في الدولـة الإسـلامية كسائر الحقـوق والحريـات، ويمكن إظهار تقييد التجنس في مسألتين:

الأولى : تقييد جنسية المسله :

أسـاس الجنـسية في الـشريعة الإسـالامية الإسـلام، فمـن أسـلم في بـلاد الإسلام ، أو نشأ بها مسلمًا، مُنح الجنسية الإسلامية، ولا يمكن سـلبها منسه، أو إسـقاطها عنـه ، أو تقيـــها إلا إذا أتـى بنـاقضِ مـن نـو اقض الإسـالام وحكـم بردته، وهنا تغيَّرت جنسيته بتغيُّر الأساس الذي قامت عليه. فإذا كان ولي الأمر هو المخول بمنح الجنسية ممثلاً عـن الدولة، فـإن مـن حقـه إذا فعـل الإنسان فعـلاً يتعـارض مـع المـصالح العامـة الدولة، كـأن تـآمر عليها، أو أفشى أسر ارًا تضر بمصلحتها ، أو ارتكـب جريمـة الخيانـة العظمي فمن سلطة وليّ الأمر حينئذٍ تقييد جنسيته بـل وإسـقاطها عنـه إذا ثبـت ارتكابـه تلك الجر ائم التي تضر مصلحة الدولة . 
منحت الثريعة الإسـلامية أهـل الذمـة الجنسية الإسـلامية نتيجـة التزامهم أحكامها، والشروط المتفق عليها مع وليّ الأمر حين إبرام عقد الذمة.

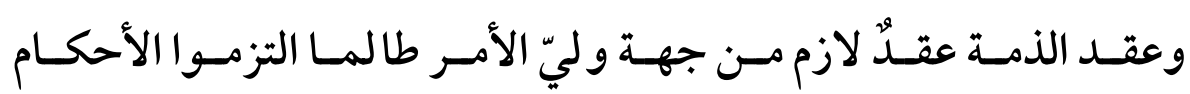

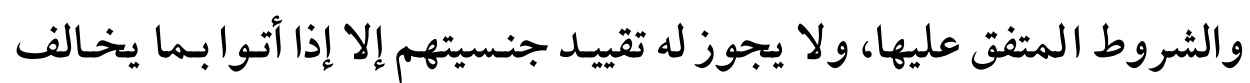

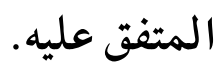
فإذا أسلم الذذمي أسقط عنه ولي الأمـر الجزيـة، ومنحه جنسية الإسـلام،

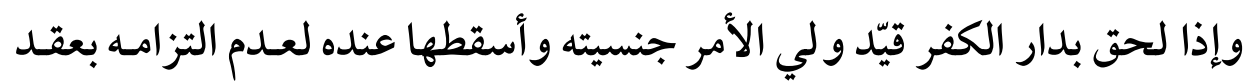

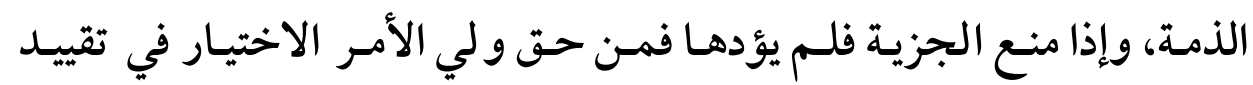

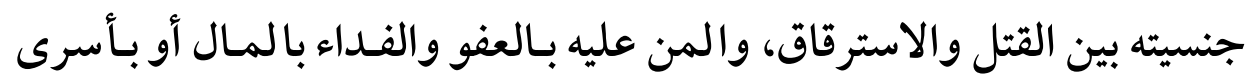
المسلمين. وكذلك إذا فعلوا أي فعلٍٍ يضر بمصلحة الدولة الإسـلامية، أو تجـاوزوا

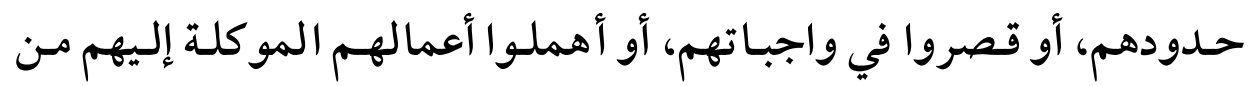
قبل وليّ الأمر، أو خيف منهم الغدر والخيانة، فبإن من حق وليّ الأمـر أيضًا أن يقيّد جنسيتهم بما يرى فيه مصلحة للدولة الإسلامية. 
(TV\&)

\section{المبحث الثاني \\ تقييد حرية المشاركة السياسية}

تقهيل:

المشار كة السياسية مصطلحُّ رنَّانٌْ رائج في الحيـاة السياسية المعاصرة،

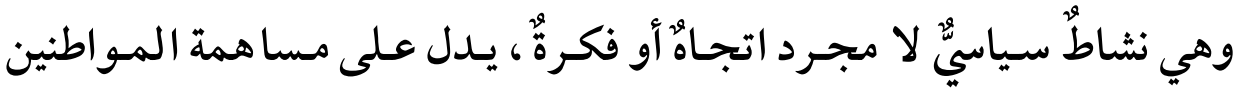

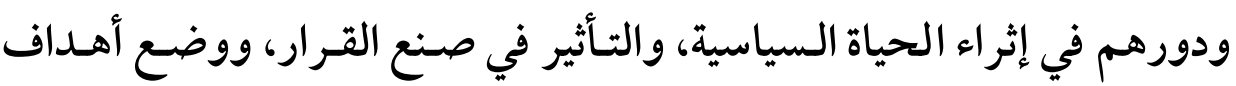

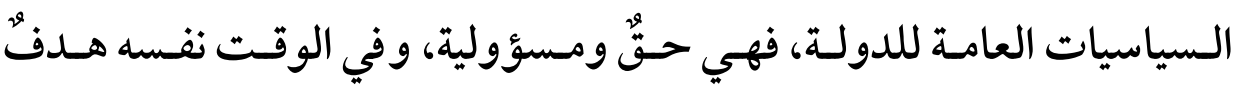

ووسيلة في آنٍ واحـدِ، تنطلب قـدراتٍ ومهاراتِ تنظيميـةٍ، وبيئة تمكنها مـن

النمو، وحكومة تقدر قيمة المشاركة السياسية الحقيقية للمواطنين.

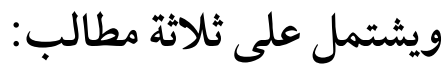

\section{المطاب الأول \\ تعريف المشاركة السياسية}

تعريف المشاركة السياسية:

هناك عدة تعريفات للمشاركة السياسية، منها:

أنهـا الأنـشطة التـي تـرتبط بالحكومـة أو الدولــة، مـن خـلال مؤسـساتها

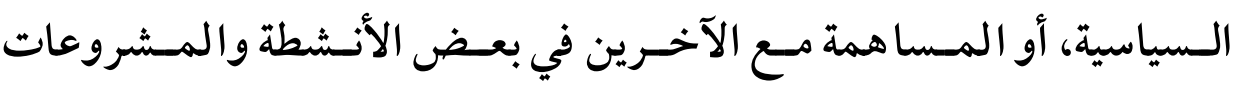

التطوعية لصالح المجتمع ( ')

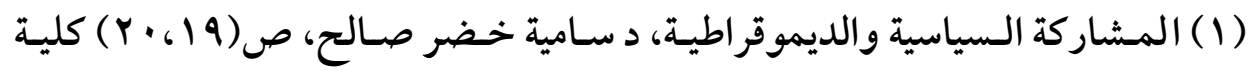

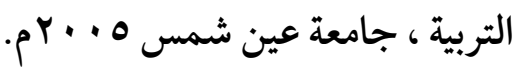


(TVO)

أو هي : النشاط الذي يقوم به المواطنون العاديون بقصد التـأثير في عملية

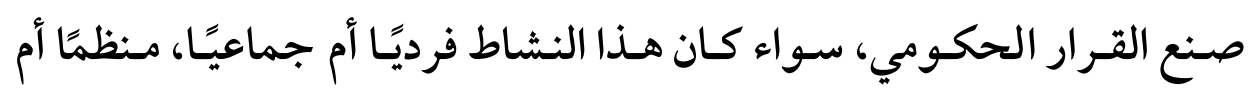

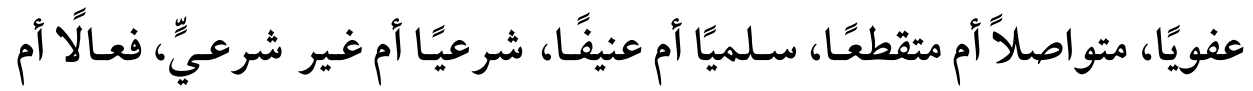

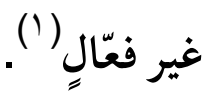
والعمل السياسي في صورته المعاصرة أعـم مـن أن يكسون تكوينًا لحزبٍٍ

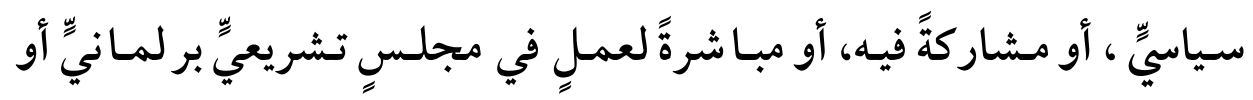

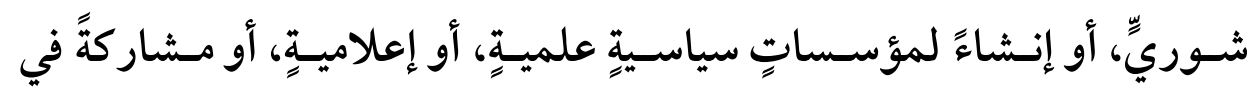

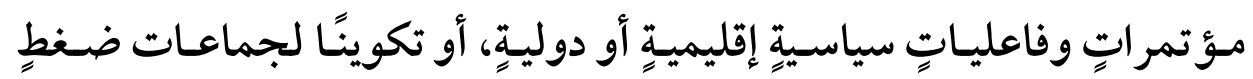

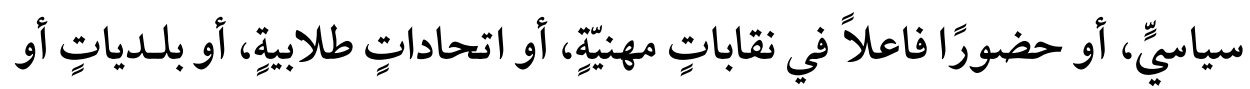
محلياتٍ، أو إيجادًا لتياراتٍ شعبيةٍ، أو إدارةً لتحالفاتِ وطنيةٍ (؟).

\section{الاطباب الثاني}

\section{صور المشاركة السياسية}

لقـــ أقـــ الإسـلام حريـة المـشار كة الـسياسية للأفـــاد داخـل المجتمـع الإسلامي، ومن أهم صور هذه المشاركة: حق الترشـح، والانتخـاب، وتولي لئي الوظائف العامة. - ائ

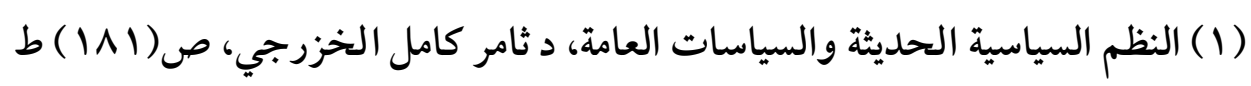

$$
\text { دار مجدلاوي، عمان ع ·. (Y) }
$$

(Y) المشاركات السياسية المعاصرة ، د محمد يسري إبر اهيم، ص(TV) (T) ط دار اليسر، 
(TVY)

| - المشاركة السياسية بالترشح :

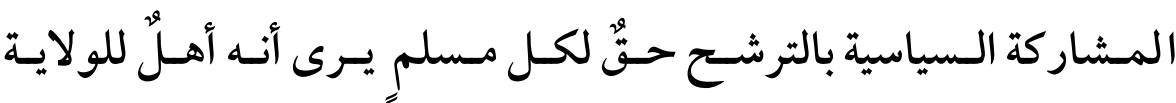

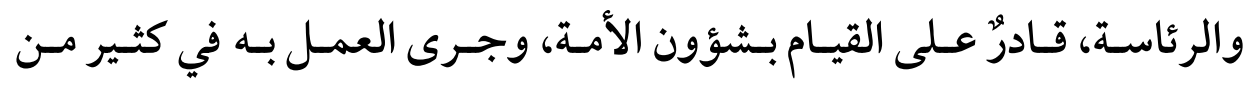
الأحداث السياسية، ومن هذه الأحداث :

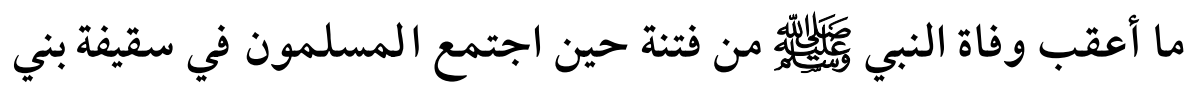

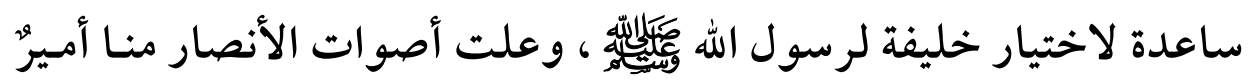

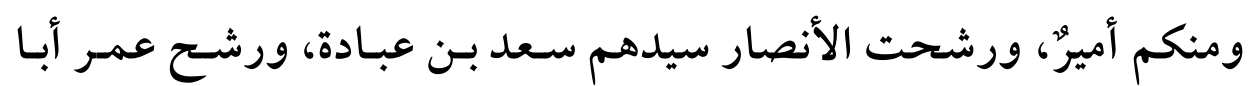

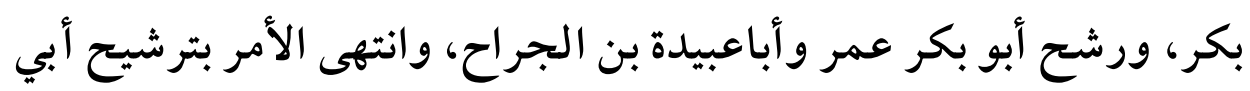

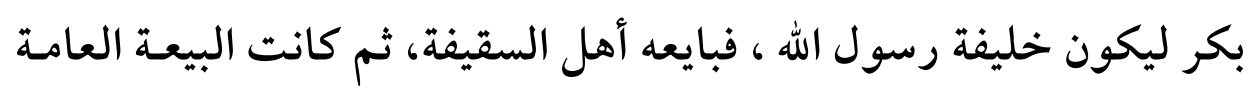

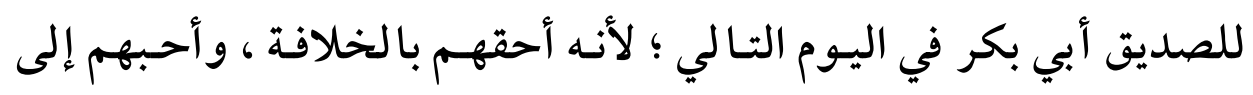

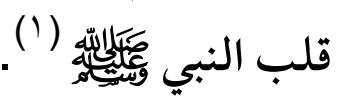

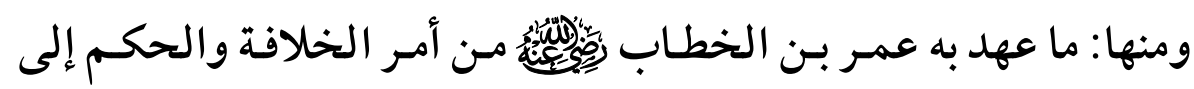

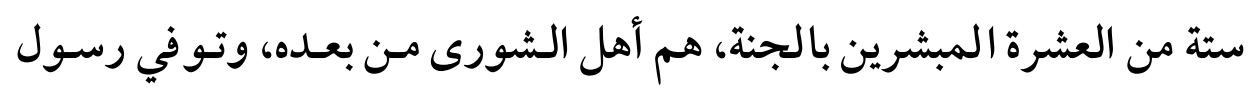

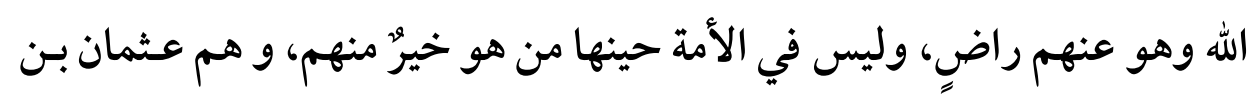

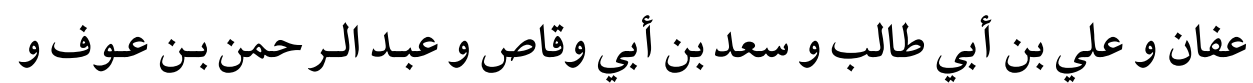

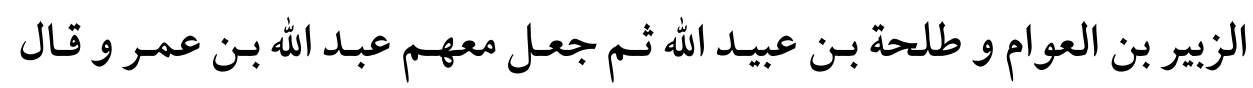

(1) البداية والنهاية للحافظ إسماعيل بن كثير (0/ / ( ) وما بعدها، ط دار إحياء التراث

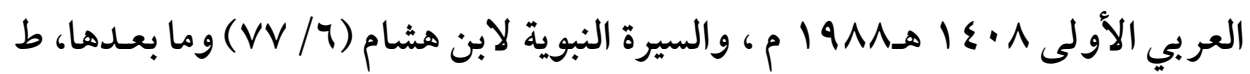
دار الجيل ، بيروت || إ اهـ ، تحقيق : طه عبد الرءوف سعد. 
ليس له في الإمارة نصيب و إنما له الاختيار و الر أي فتشاوروا ثلاثة أيسامٍ ، ثم

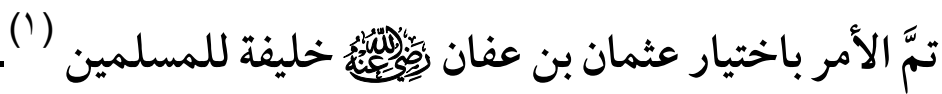
فـإن مـا تـم في السقيفة مـن ترشسيح الأنسصار لسعد بـن عبـاده، وترشسيح المهاجرين لأبي بكر وعمر وأبي عبيدة، واستخلاف عمر لستة من المبشرين

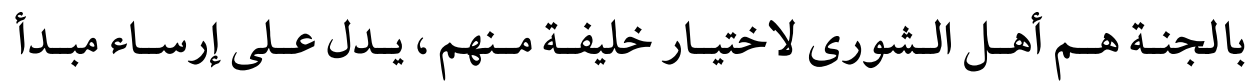

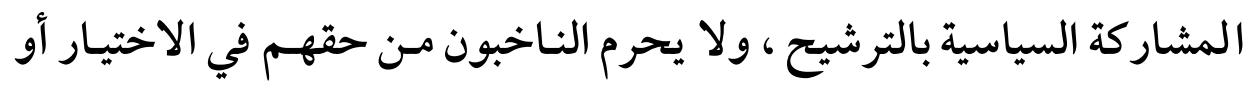
الرفض، ولا يتم الأمر ولا يستقيم إلا بالبيعة العامة. r- المشاركة السياسية بالاتتخاب :

لقد أثبتت الوقائع التاريخيـة مشار كة المسلمين السياسية بالانتخـاب في

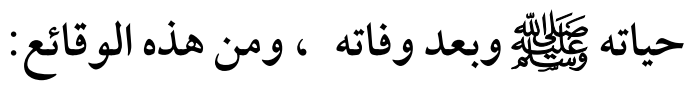

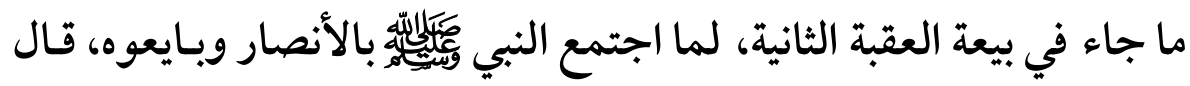

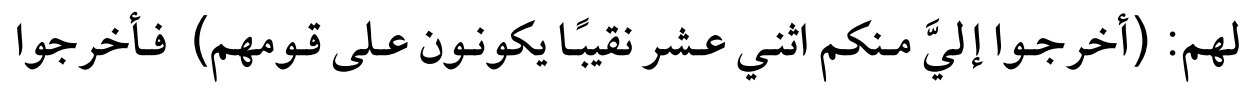

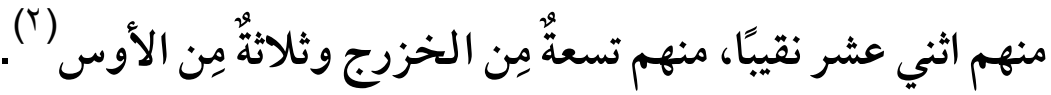
ومنها : ما جاء في مشار كة المسلمين السياسية بانتخـاب عثثمان بـن عفـان

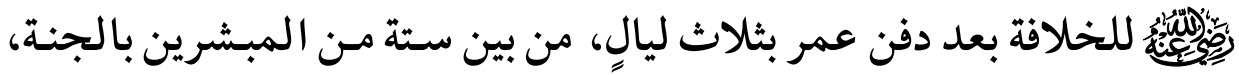

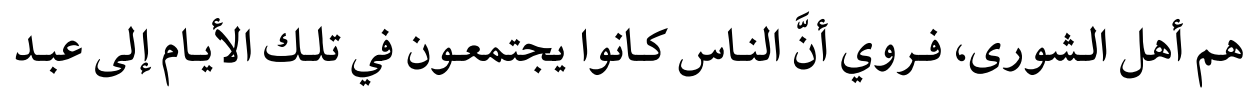

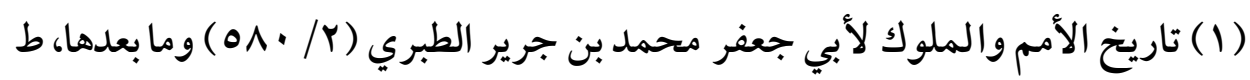

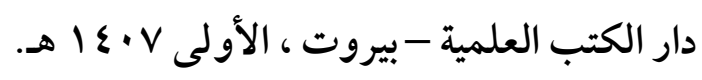
(Y) أخرجه أحمد في مسنده، بقية حديث كعب بن مالك الأنصاري، رقم( Y OV9N). 
(TVA)

سلطة ولي الأمر في تقييد العريات السياسية للمصلحة العامة

الر حمن بـن عوف يشاورونه و يناجونـه، فلا يخلوا بـه رجلٌ ذو رأي فيعـدل بعثمان أحدًا، و لما جلس عبد الر حمن للمبايعة حمـد الله و أثنى عليه، وقـال في كلامه : إني رأيت الناس يأبون إلا عثمان (').

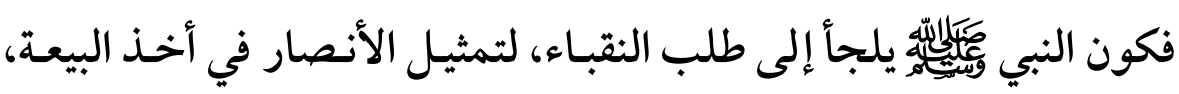

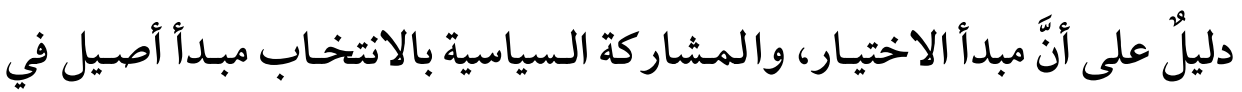
الشريعة الإسلامية.

وقد تجلى هذا المبدأ بوضوح حين مارس الصحابة حقهم في الانتخاب

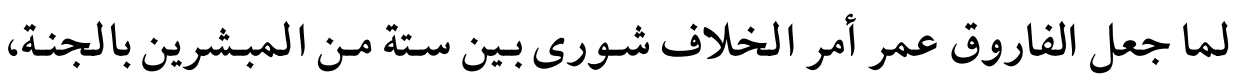
بل وحدد لهم المدة التي تنتهي فيها عملية الانتخاب، فاختار الصحابة عثمان

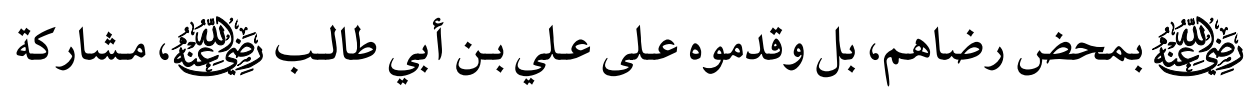
منهم في انتخاب الخليفة على أساس المصلحة العامة للمسلمين.

\section{r- المشاركة السياسية بتولي الوظائف العامة :}

لقد كفلـت الشريعة الإسـلامية الحـق في تـولي المناصب العامة بالدولة لجميع المسلمين، وحققت العدل والمساواة بينهم، بل وأرست مبـدأ تكـافؤ

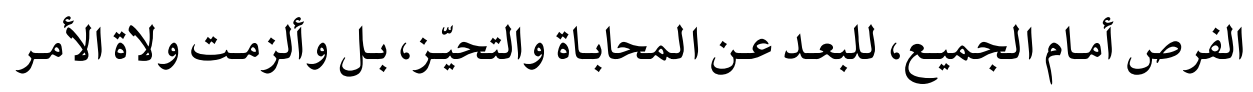

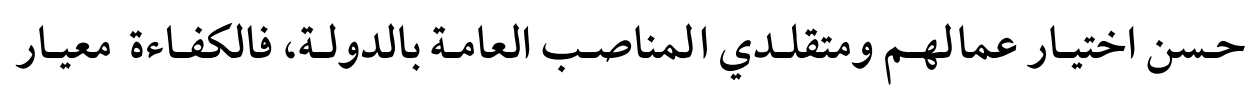

(1) تاريخ الخلفاء لعبد الرحمن بن أبي بكر السيوطي ، ص( I I ) مط مطبعة السعادة -

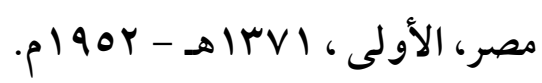


الاختيار ، فلـم تكـن الوظيفـة أبـدًا لمـن طلبها، وإنما كانـت لمـن اسـتحقها، وكان كفئًا لها.

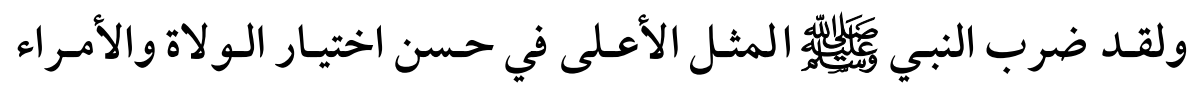

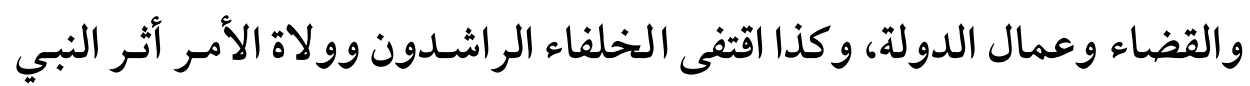
في ذلك.

ومن الولاة الذين اختـارهم النبي للقيـام بمـصالح الأمـة، وتـدبير شـؤونها:

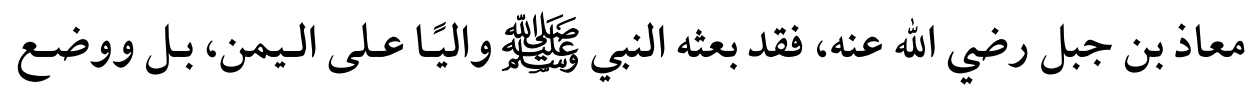

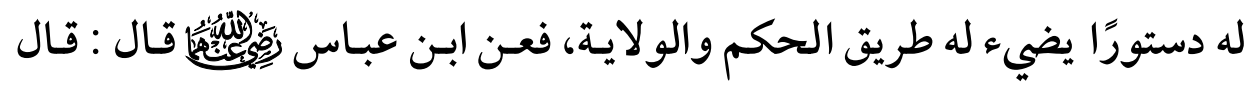

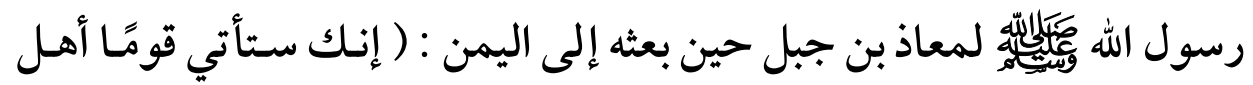

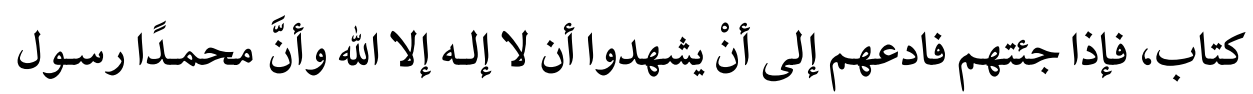

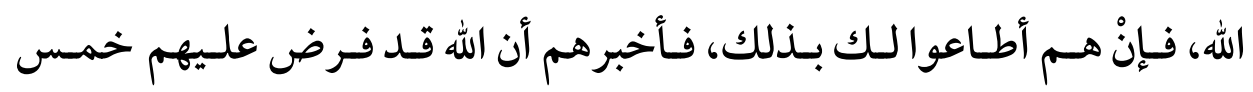

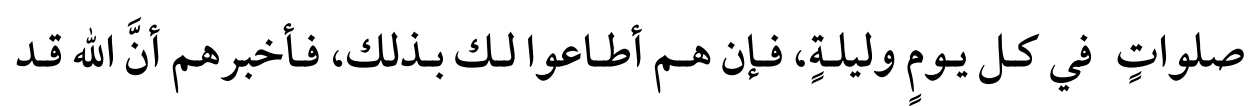

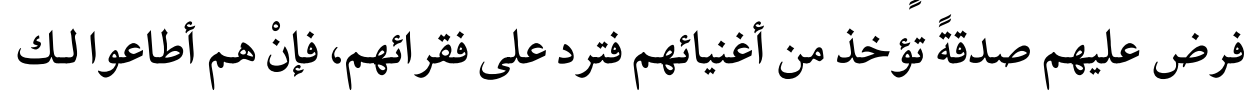

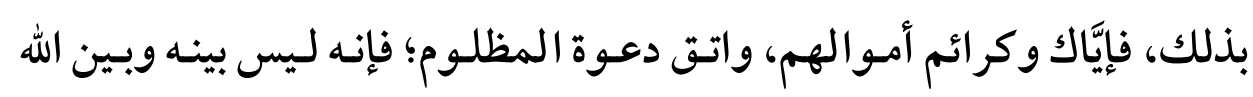

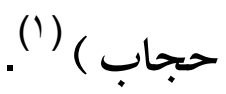

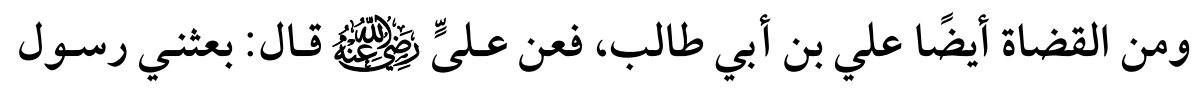

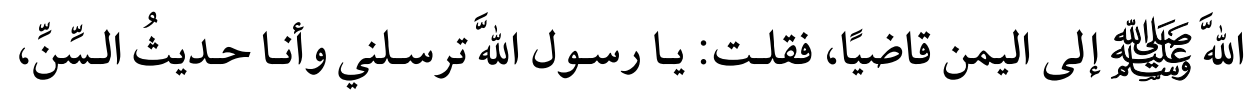

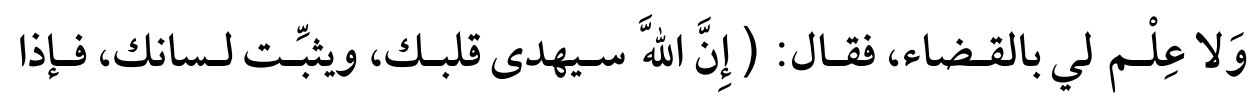
ف (1) أخرجه البخاري في صحيحه، كتاب الجمعة، باب أخْذ الصَّدقة مِن الأغنياء وتُردَّ

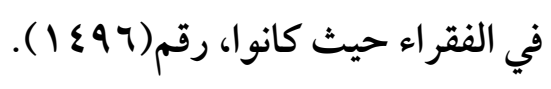


$(7 \wedge \cdot)$

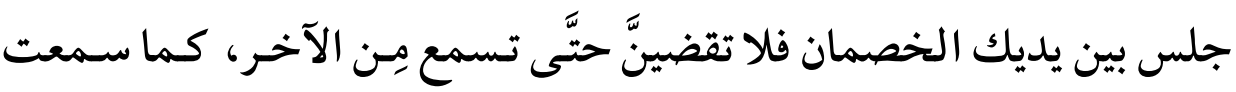

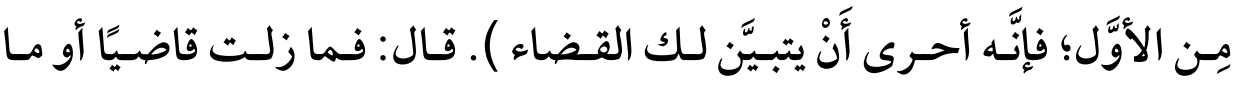

شككت في قضاءِ بعد (' ')

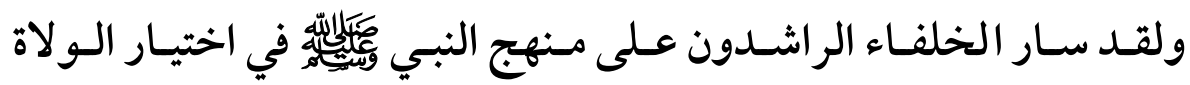

والقضاة وعمال الدولة من أهل الكفـاءة والقوة والأمانـة والقـدرة على القيـام بمهام الوظيفة العامة، والتي تتعلق بها مصالح العباد والبلاد. فاستعمل أبو

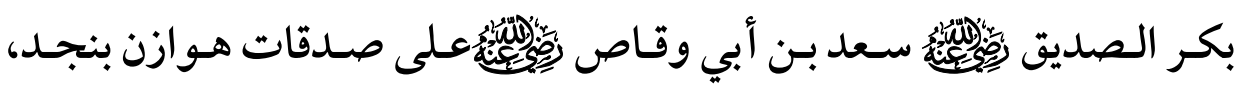
وأقره عمر عليها (؟).

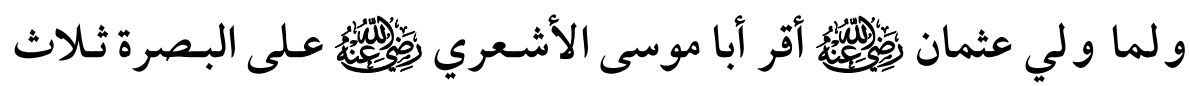

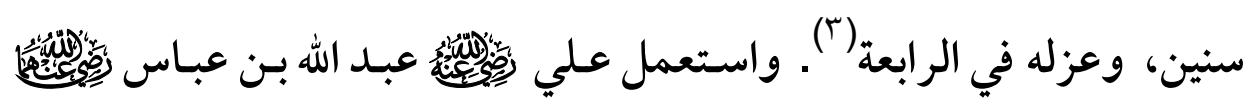

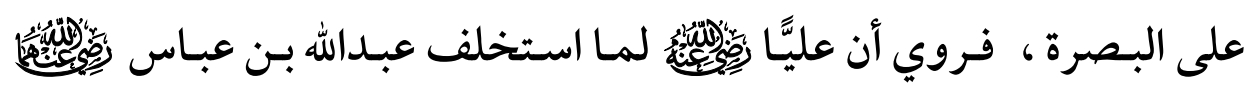
على البصرة سار منها إلى الكوفة، فتهيأ فيها إلى صفين، فاستشار الناس في

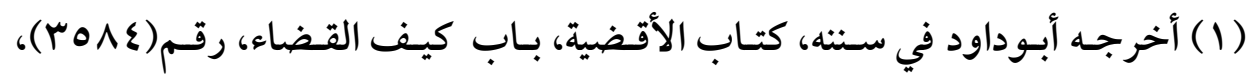

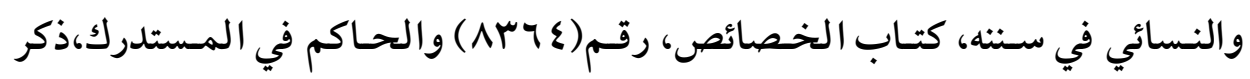

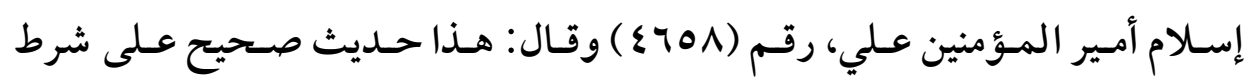

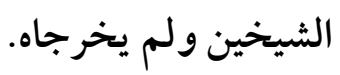

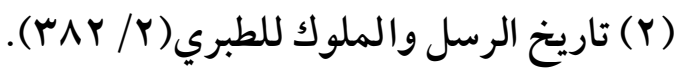

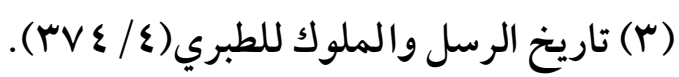


(71)

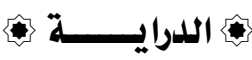

ذلك، فأشار عليه قومُ أن يبعـث الجنود ويقيم، وأشـار آخـرون بالمسير فأبى

إلا المباشرة (') - (')

أوضـحت هــه الوقـائع والأحسداث بـما لا يـــع مجـالا للـشك أنَّ الشريعة

الإسـلامية كفلـت حـق تقلّــد الوظـائف العامـة بالدولـة، عـلى أسـاس الكفـاءة

والقوة والقدرة على القيام بمهام الوظيفة العامة، على خير مـا يكون القيام،

وهي تختلـف بـاختلاف الوظيفـة، فضلاًا عـن الأمانـة والـوازع الـديني الـذي يحمل المتولي لوظيفة من الوظائف العامة بالدولة خشية الله تعالى، ومر اعـاة

المصلحة العامة للأمة.

\section{المطلب الثالث}

\section{سلطة ولي الأهر في تقييد المشاركة السياسية}

تقــر سـلفًا أن المـشار كة السياسية حسقّ كفلتـه الـشريعة الإسـلامية لكـل

المسلمين ، ضـمن الحـدود والضضوابط الـشرعية، فـإذا تـوفرت الشروط في

الفرد جاز له ممارسـة حقـه في المششاركة السياسية دون قيدٍ أو شرطِ، أمـا إذا لم تتوفر الشروط، أو تم تجاوز الضوابط الشرعية، أو ترتب على هـذه الحرية المطلقة مفسدة محققـة، جاز لوليّ الأمـر تقييدها؛ مراعـاة للمصلحة العامـة للمسلمين، لأن تصرفه في الرعية منوط بالمصلحة.

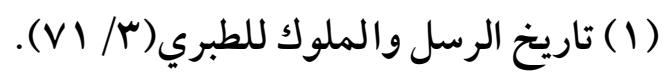


$(T \wedge Y)$

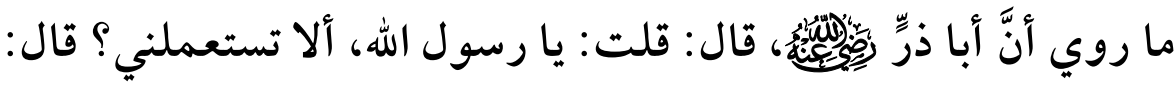

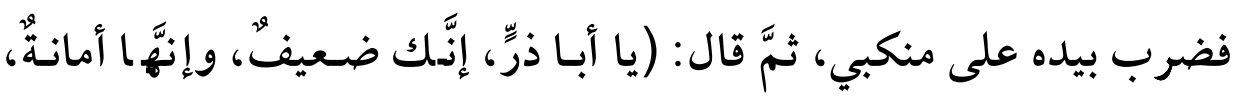

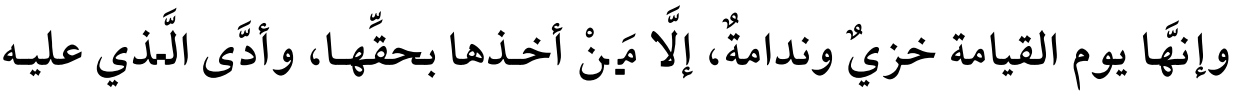

فيها) (')

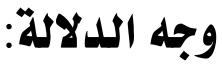

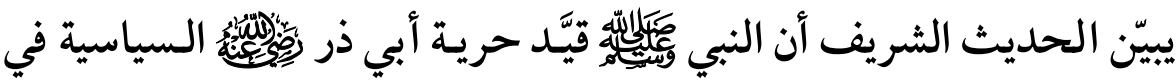

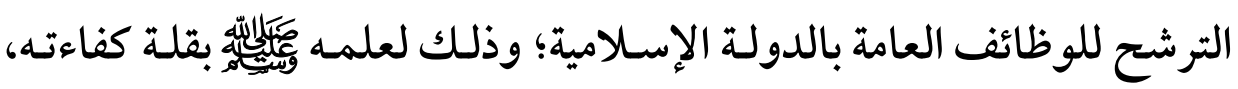
وعدم قدرته عـلى القيام بمهام الوظائف العامـة على الوجـه الأكمـل ، عـلاوة

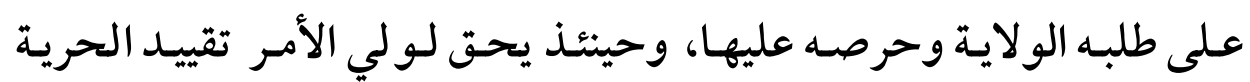
السياسية لبعض الأفراد مر اعاة للمصلحة العامة للمسلمين.

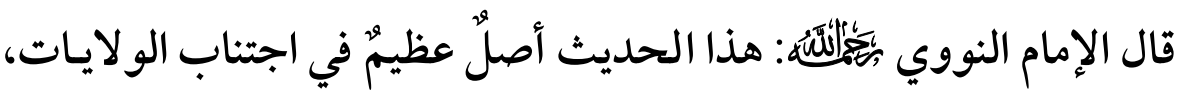

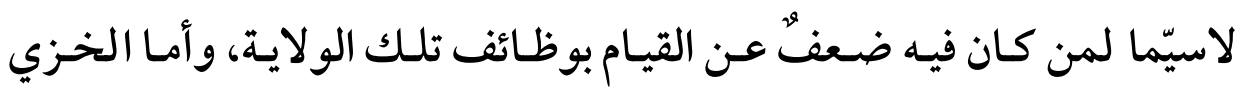

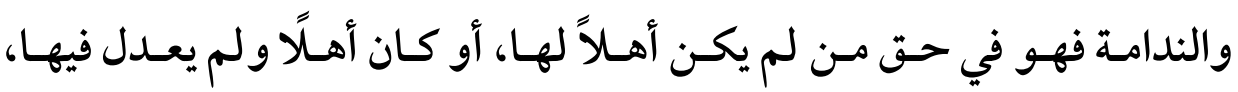

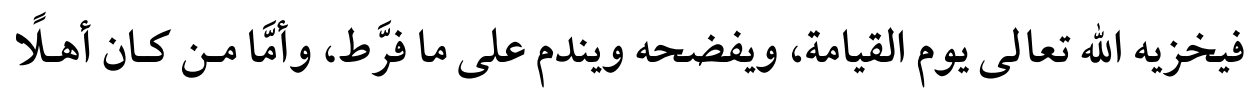

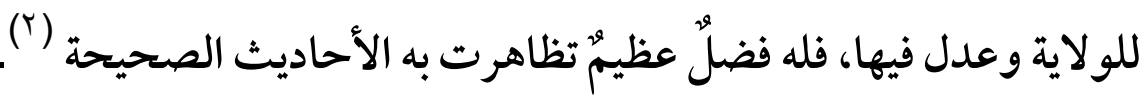
(1) أخرجه مسلم في صحيحه، كتـاب الإمـارة، بـاب كراهـة الإمـارة بغـير ضرورة،

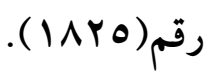
(Y) المنهاج شرح صحيح مسلم بـن الحجـاج لأبي زكريـا يحيى بـن شرف بـن مري

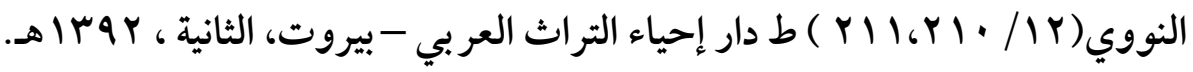




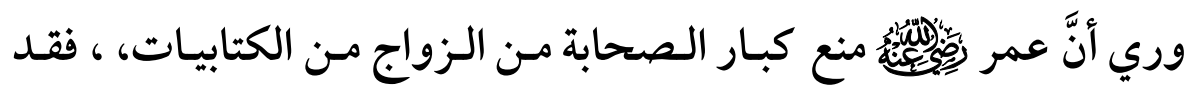
روي عن شقيق بن سلمة قال: تزوج حذيفـة يهوديـة، فكتـب إليه عمـر :خَلِّ

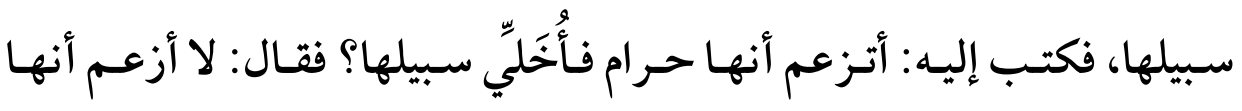
حرامُ، ولكني أخحاف أن تعاطو ا المومسات مـنهن · وروى أن طلحة بـن عبيد الله نكح بنت عظيم اليهود قال فعزم عليه عمر إلا ما طلقها. قال الطبري : وإنـما ذكـره عمـر لطلحـة وحذيفـة رحمـة الله عليهم نكـاح اليهودية والنصرانية، حـذرًا مـن أن يقتـدي بهـما النـاس في ذلك، فيزهـدوا في

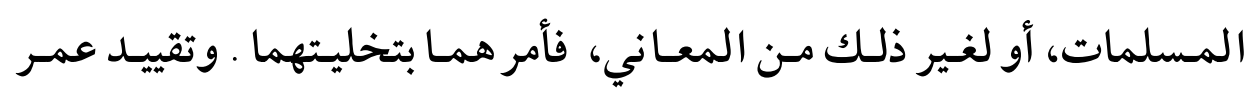

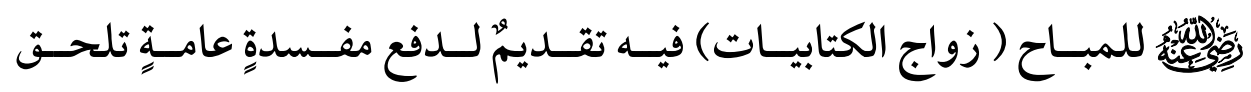
بالمسلمات، على جلب منفعةٍ خاصةٍ لمن أراد الزواج مـن الكتابيات، فضلًا عن أن هذه المنفعة تتحقق بالزواج من المسلمات.

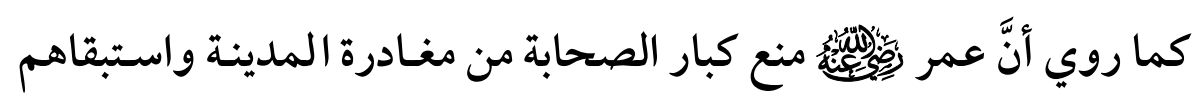
إلى جانبه ليكونوا له بمثابة المشيرين الذين يرجع إليهم إذا ادلهمـت الأمور، ومنعهم من الانتشار في الأمصار لإلا بإذنه، أو لمهمة رسمية كتعيين بعضهم

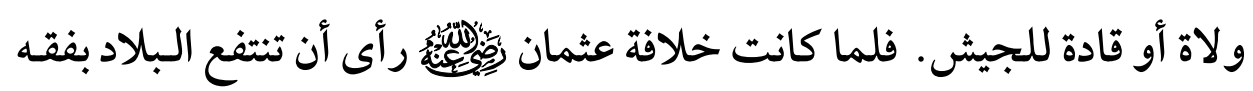
الصحابة و علمهم، وينتفعوا هم بما يرون في البلاد من حضارة، فرخص لهم في السفر. 
$(\neg \wedge \varepsilon)$ سلطة ولي الأمر في تقييل الحريات السياسية للصلحة العامة

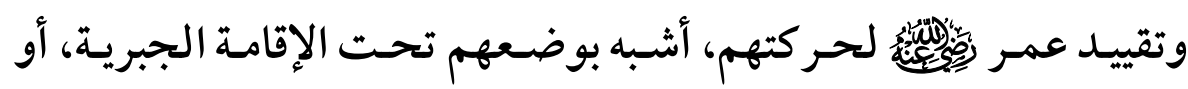

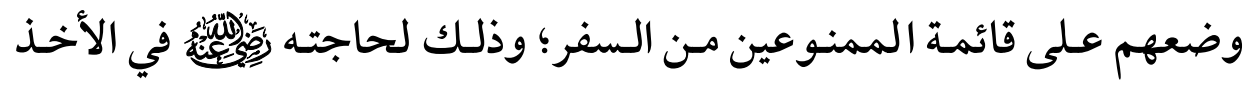

بـر أيهم ومسشور تهم ، والاسـتفادة مـن خـبر اتهم ، فتقييـد حـريتهم في التنقل ترتبت عليه مصلحةٌّ عامةٌ يعود نفعها على جميع الأمـة، وعليه فمـن حقى ولي

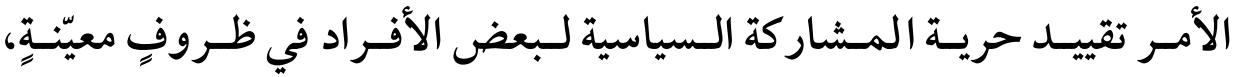
وأوقاتِ معيّنةِ، و ممارساتِ معينة ، مراعاةً للمصلحة العامة للمسلمين · 
(7^o)

\section{المبحث الثالث \\ تقييد حرية التعبير عن الرأي}

حرية التعبير عن الـرأي مـن المواضـيع المستجدة عـلى الساحة الفكرية،

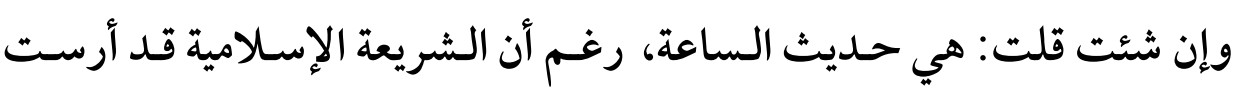

دعائمهـا، وكفلتهـا بمفهومهـا الإسـلامي المنـضبط، الـذي يمنـع التعـدي ، و يحفظ الحقوق، ومـا كانت الشريعة الإسلامية لتترك تلك الحريـة مطلقةً بدون قيودٍ وضوابط شرعية؛ حتى لا يعبرّ مَن شـاء بـما شـاء وكيف شـاء بعيدًا

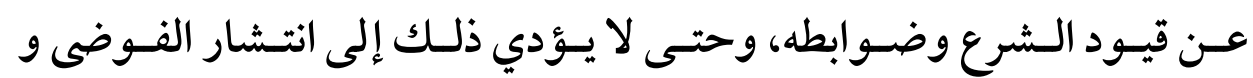

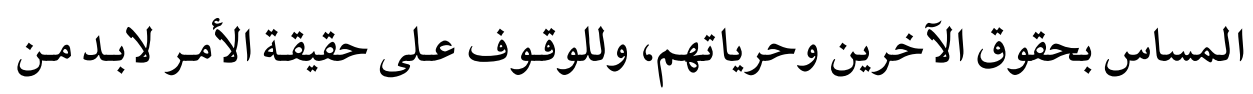
معرفة حقيقة التعبير عن الر أي ، ومشروعيته، وضوابطه.

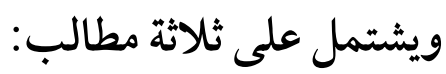

\section{المطاب الأول \\ حقيقة التعبير عن الرأي وهشروعيته \\ حقيقة التعبير عن الرأي :}

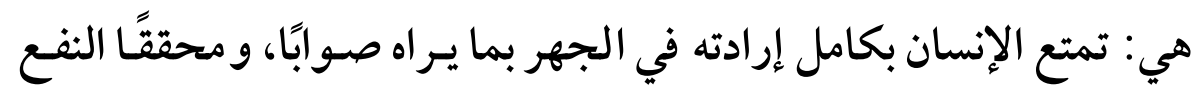

له وللمجتمع، ساءُ تعلَّق بالشؤون الخاصة أو القضايا العامة (' ل.

(1) قرارات وتوصيات مجمع الفقه الإسلامي الدولي، منظمة المؤتمر الإسلامي، قرار

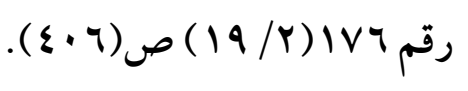


(TAY)

سلطة ولي الأمر في تقييد العريات السياسية للمصلحة العامة

أوهي: تمتع الإنسان بكامـل حريته في الجهر بالحق،وإسـداء النصيحة في كل أمور الدين والدنيا، فيما يحقق نفـع المسلمين،ويصون مصالح كلٍ

من الفرد والمجتمع،ويحفظ النظام العام (')

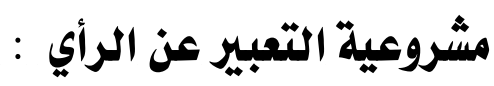

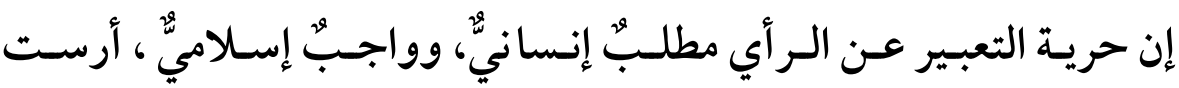
قواعده الشريعة الإسلامية، وشرعته للمسلمين؛ لأنهم مأمورون بالدعوة إلى الله، والأمر بالمعرف بمعروفٍ، والنهي عن المنكر بغير منكـر، فحريـة التعبير عن الر أي حقّ من جهة صاحبه، وواجب من جهة مصلحة المجتمع، والتعبير عن الر أي بـضو ابطه الشرعية بوسـائل العصر المتاحة ، يلعب دورً فـاعلًا في التصحيح و إظهار الحق، بـل يُعـدّ شـكلاً مـن أشكال الجهاد بالكلمـة ؛ لأن

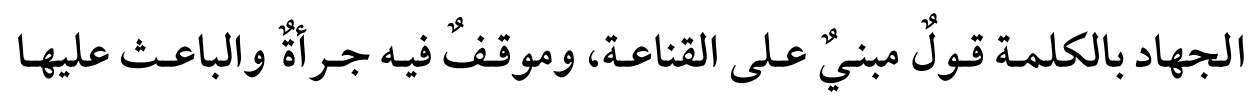
المصلحة العامة للمسلمين. ولقد كثرت الأدلة على مشروعية التعبير عن الر أي ، ومن هذه الأدلة:

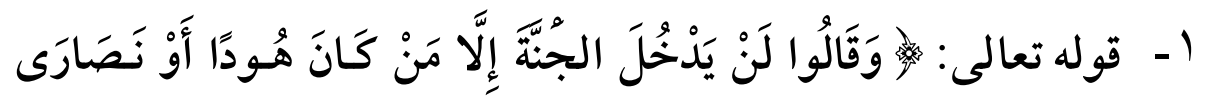

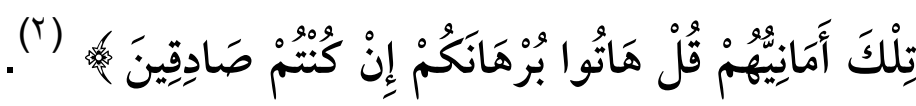
(1) حقوق الإنسان في الإسلام، د سليمان بن عبدالر حمن الحقيل، ص(ع ه) ط وكالة

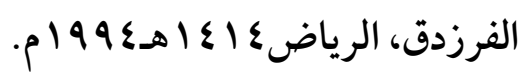
(Y) (Y) (Y) (111) (11). 


\section{وجه الدلالة: - و الد}

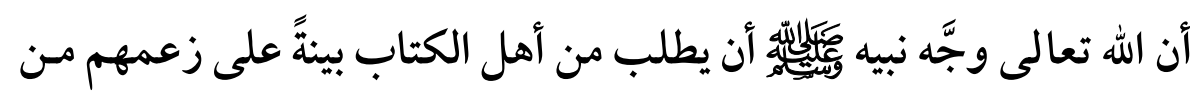

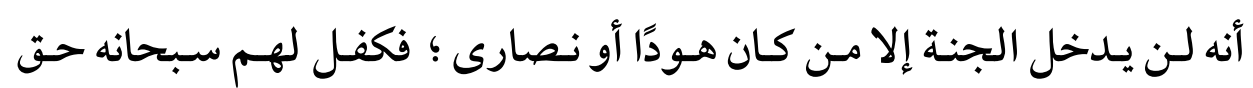

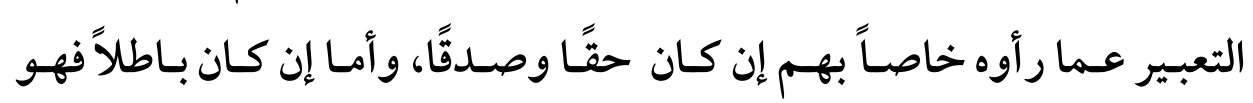

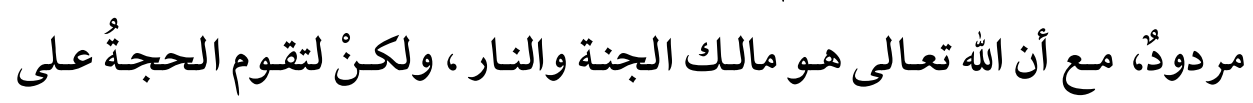
المخالف، وليتنبه الغافل المقلّدّ وليكون على بينةٍ من أمره ( ').

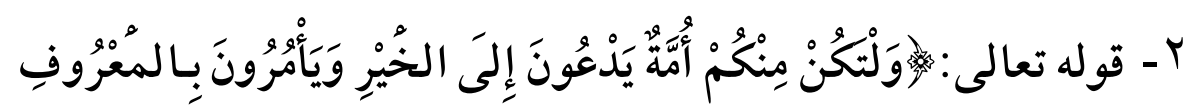

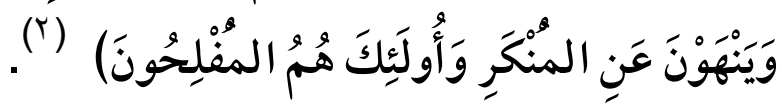

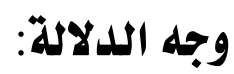

أمر الله المؤمنين بالأمر بالمعروف والنهي عن المنكر، وهما مـن مظاهر

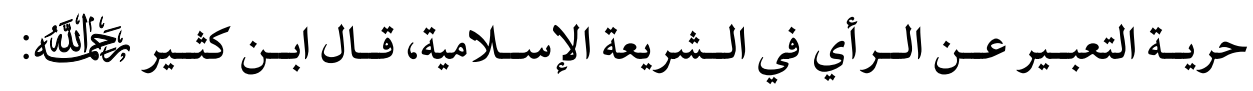

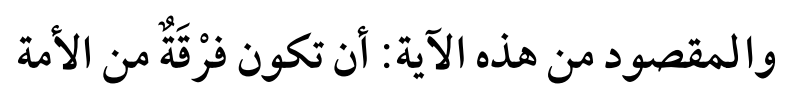

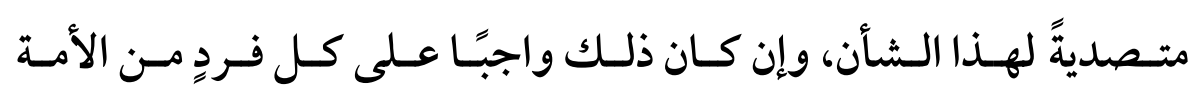

(ए)

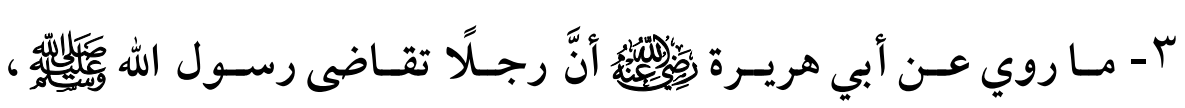

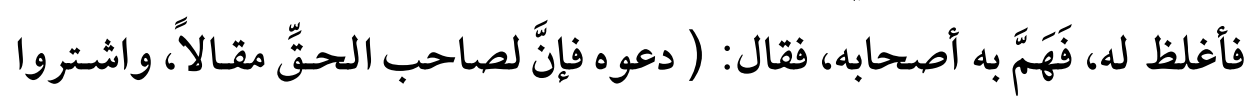

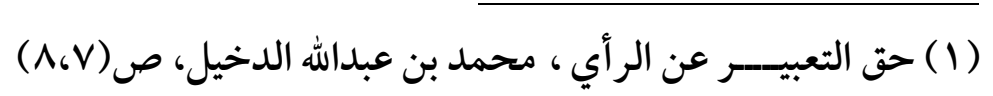

Mohamd-o10@hotmail.com .ه أه أن

$$
\begin{aligned}
& \text { (Y) سورة آل عمران، الآية (؟ - (1)). } \\
& \text { (Y) تفسير ابن كثير (Y) (Y) (Y) }
\end{aligned}
$$


(T^A)

سلطة ولي الأمر في تقييد العريات السياسية للمصلحة العامة

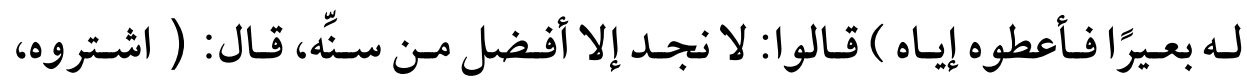

فأعطوه إياه، فإنَّ خير كم أحسنكم قضاءً ) ( ').

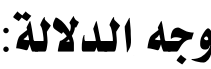

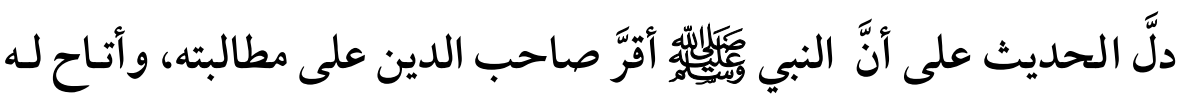

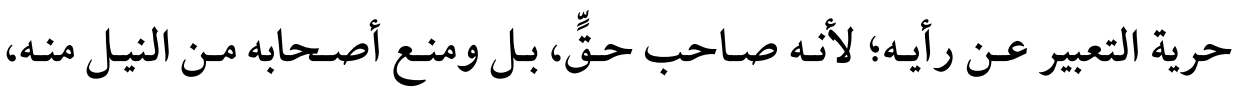

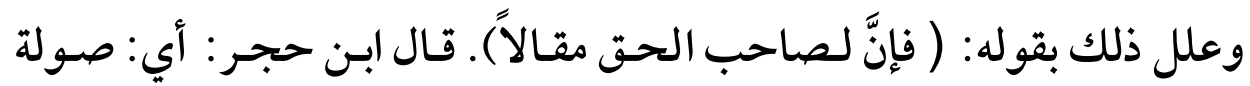
الطلب وقوة الحجة، لكن مع مر اعاة الأدب المششروع...و في الحـديث جـواز

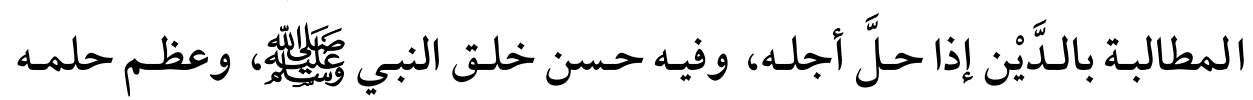

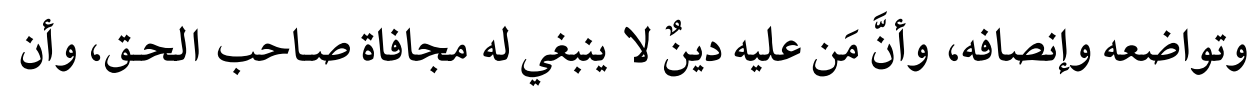

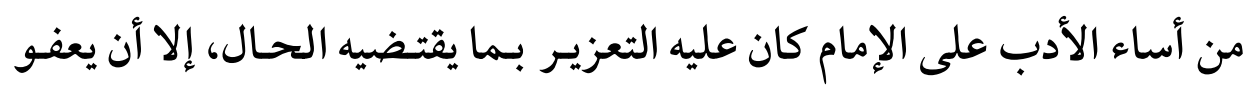
صاحب الحق (r). ع - ما روي أنَّ طارق بن شهابٍ (َّ) قال: أوَّل مَن بداً بالخُطبة يوم العيد

(1) أخرجسه البخـاري في صسحيحه، كتـاب في الاسـتقر اض وأداء الـديون والحجـر

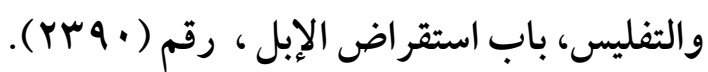

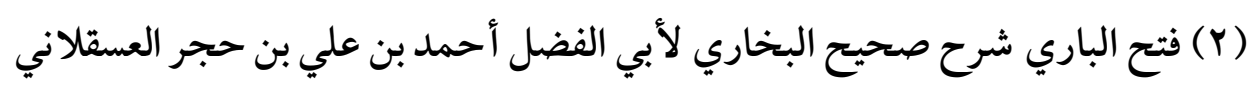

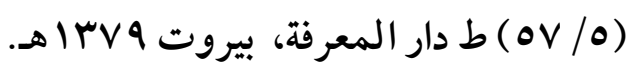

(r) هو : طارق بن شهاب بن عبد شمس بن سلمة البجلي الأحمسي أبو عبد الله، رأى النبي صلى الله عليه و سلم وهو رجل، ويقال: إنه لم يسمع منه شيئا. قال البغوي: ونزل الكوفة. وغزا في خلافة أبي بكر. 
قبل الصَّلاة مروان(') فقام إليه رجلٌ فقال: الصَّلاة قَبل الخُطبة ! فقـال: قد هـ

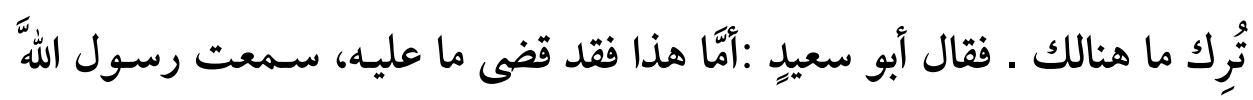

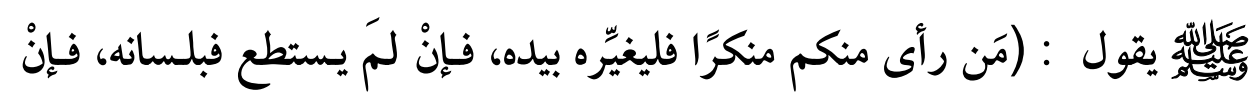

\section{لمَ يستطع فبقلبه، وذلك أضعف الإيمان) (r).}

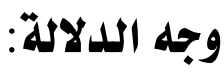

دل الحديث صر احةً على حرية التعبير في الإسلام، فهذا الرجل الذي قام

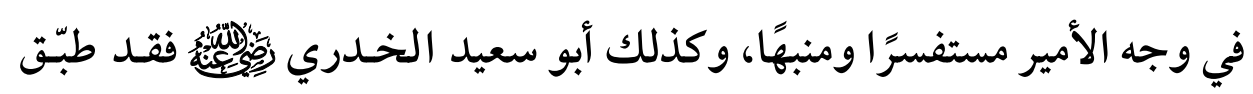

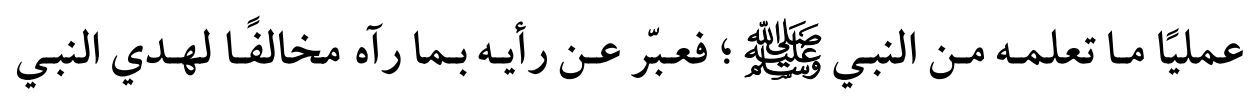

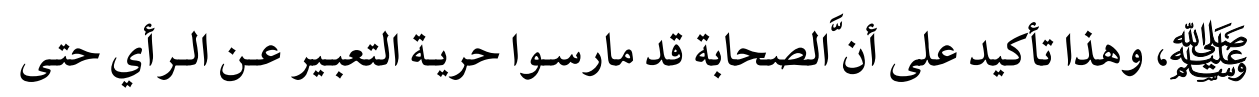

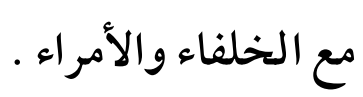

الإصابة (r/ • • (ه)، والهداية والإرشاد في معرفة أهل الثقة والسداد لأبي نصر أحمد

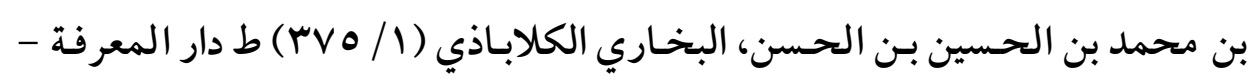

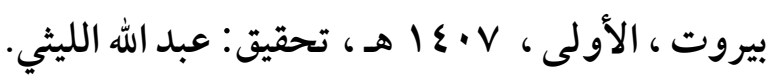

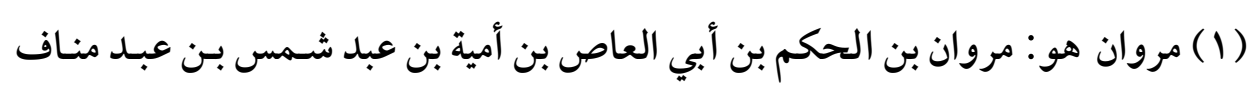

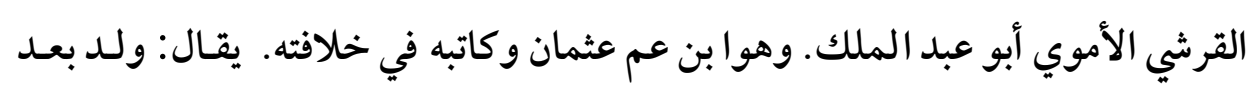
الهجرة بسنتين وقيل: بأربع.

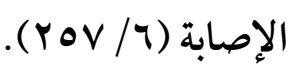

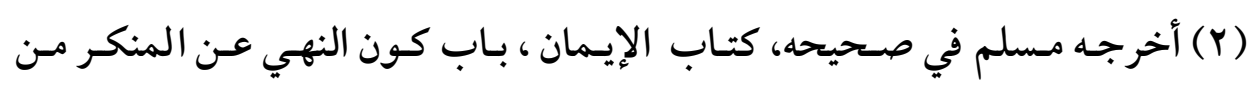

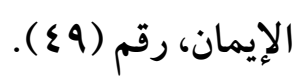


$(79 \cdot)$

سلطة ولي الأمر في تقييل الحريات السياسية للصلحة العافة

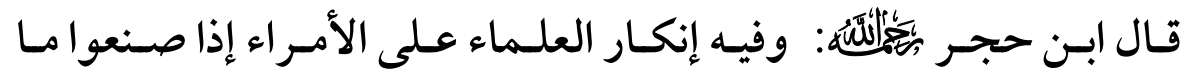
يخـالف السنة، وفيسه حلـف العـالم عـلى صـدق مـا يخبر بـه، والمباحثـة في

(الأحكام (') - (1)

من خلال تلك يظهر مـدى اهـتمام الشريعة الإسـلامية بحريـة التعبير عـن

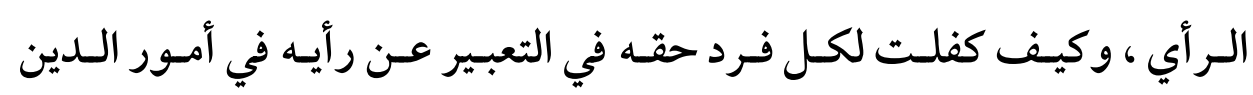

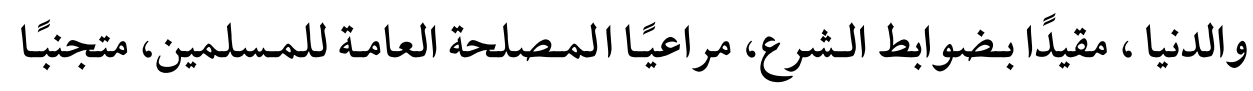

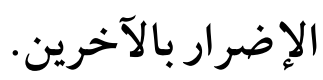

\section{الامطاب الثاني

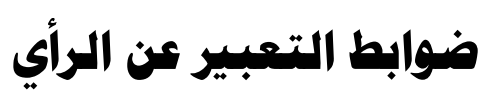

ضوابط التعبير عن الرأي (r)

إن التعبير عن الر أي هـو جهاد الكلمـة، وحريـة التعبير عـن الرأي ليست

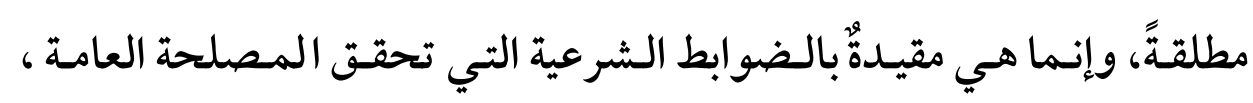

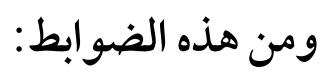

ا - عدم مخالفة الشريعة الإسـلامية : فحريـة التعبير عـن الر أي لابـد وأن

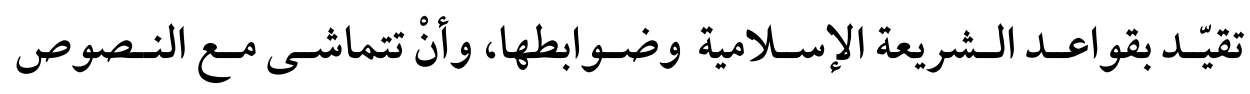
الشرعية، وتراعي المصلحة العامة.

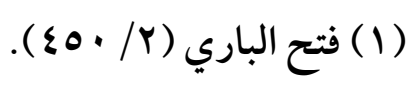

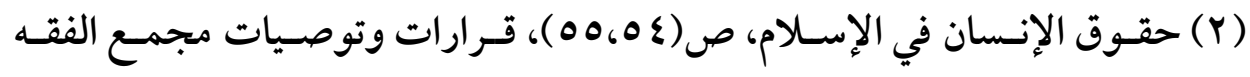

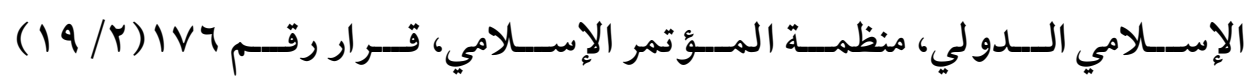

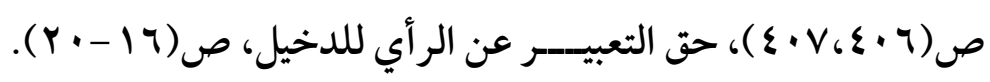


r - عدم الإساءة للغير، واحترام الآخر : فإذا كان الر أي يتعلق بأشـخاصٍ

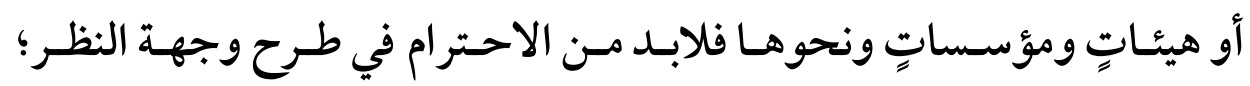

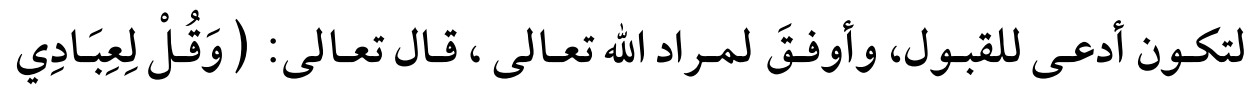

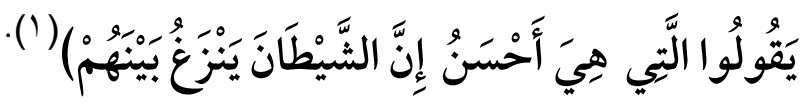

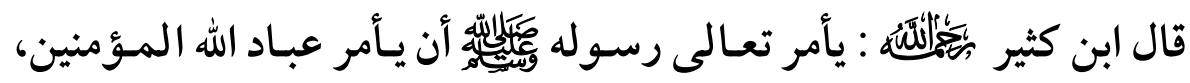
أن يقولوا في مخاطباتهم و محاوراتهم الكلام الأحسنَ والكلمة الطيبة؛ فإنه إذ لم يفعلوا ذلك، نزغ الشيطان بينهم، وأخرج الكـلام إلى الفعال، ووقع لهـ الشر والمخاصمة والمقاتلة، فإن الشيطان عدو لآدم وذريته (ז).

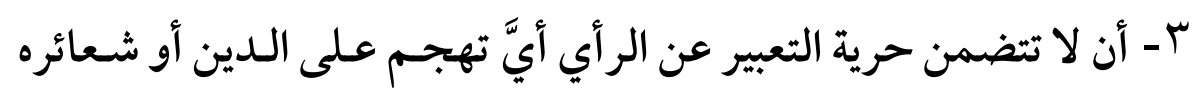

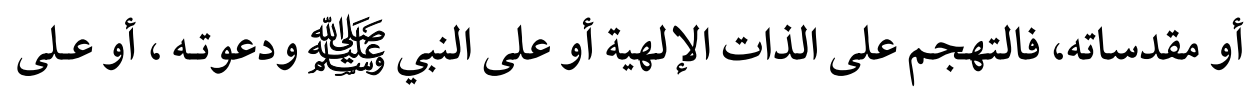
شعائر الدين بالاستهزاء ونحو ذلك انحر افتُ مبينٌ ، وزيغٌ كبيرٌ.

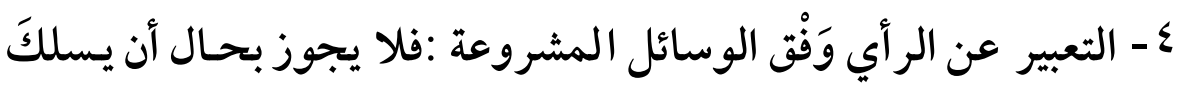

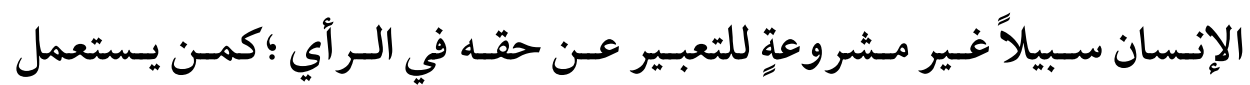

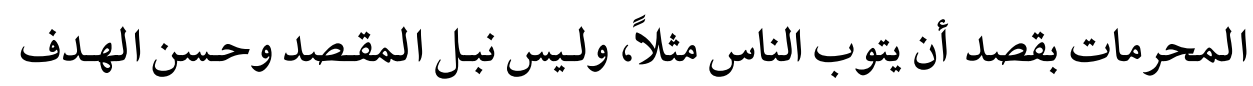

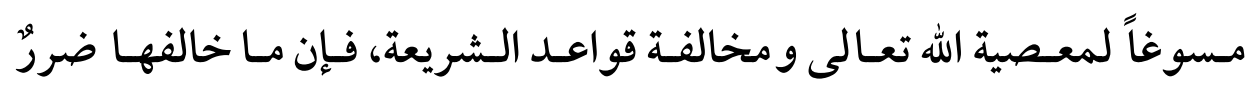
وفسادُ، ولا يترتب عليه مصلحة.

$$
\begin{aligned}
& \text { (1) سورة الإسراء، من الآية (rه). } \\
& \text { (Y) تفسير ابن كثير (AV،AT/0). }
\end{aligned}
$$


(79r)

سلطة ولي الأمر في تقييد العريات السياسية للمصلحة العامة

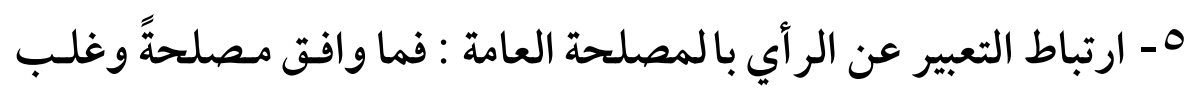

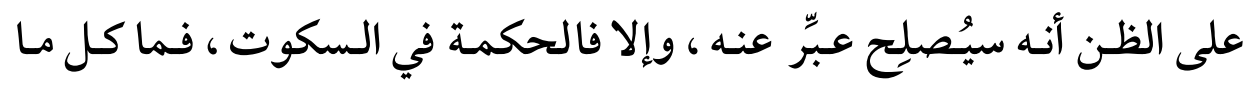
يُعلم يقال ، وما كل ما يقال يُصدَّق .

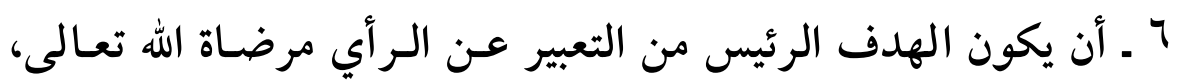

وخدمة مصلحة من مصالح الناس الخاصة أو العامة.

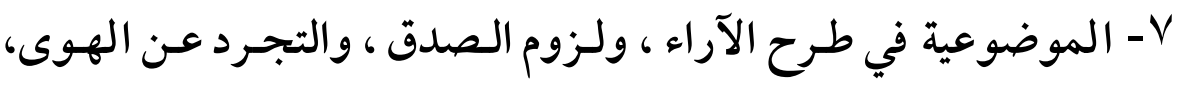

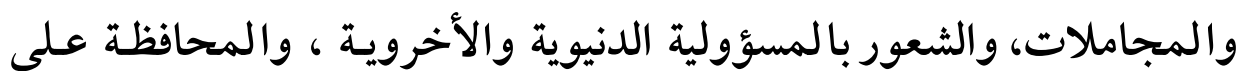
مصالح العباد والبلاد، وعلى القيم والآداب.

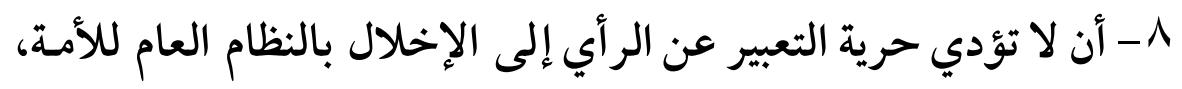

وإحداث الفرقة بين المسلمين.

9 - أن تؤخذ بالاعتبار المآلات والآثار التي تنجم عن التعبير عن الر أي،

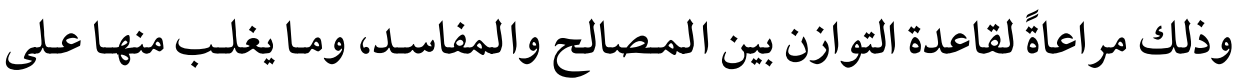

الآخر.

• ا - أن يكسون الـرأي المعبّر عنـه مسستنداً إلى مـصادر موثوقـة ، وأن

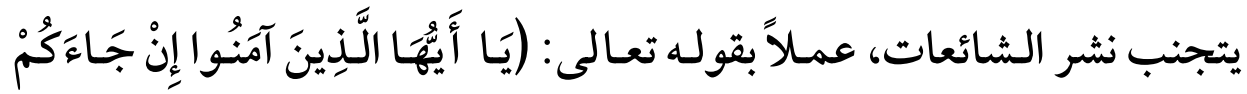

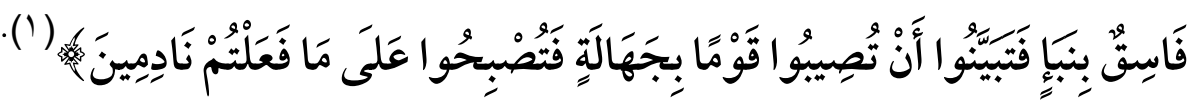

(1) سورة الحجرات، الآية (؟). 


\section{المطلب الثالث}

\section{سلطة ولي الأهر في تقييد حرية التعبير عن الرأي}

لقد كفلـت الشريعة الإسـلامية حتق حريـة التعبير عن الر أي ، ولم تتركه

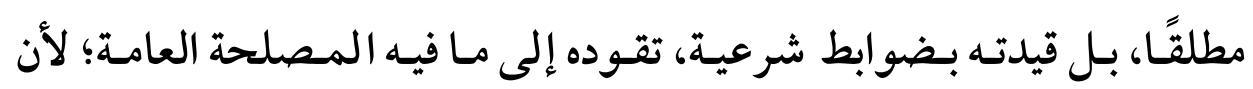
مدار هـذا الحقق على قاعـدة "جلب المصالح ودرء المفاسـد" فلـو لم يقيّد

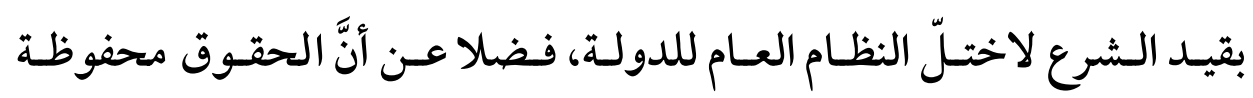

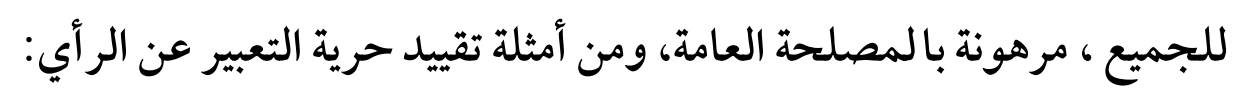

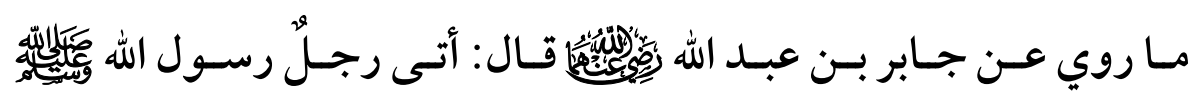

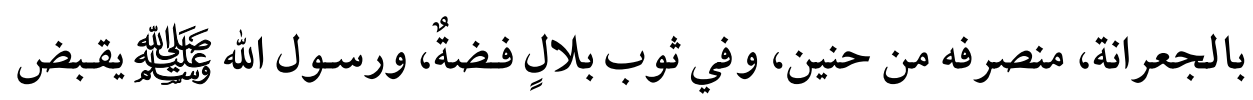

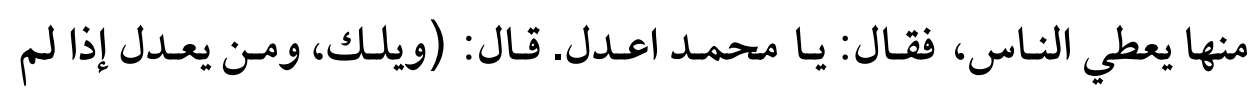

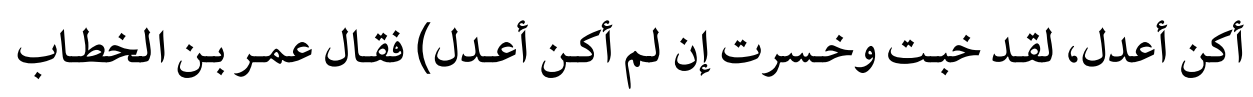

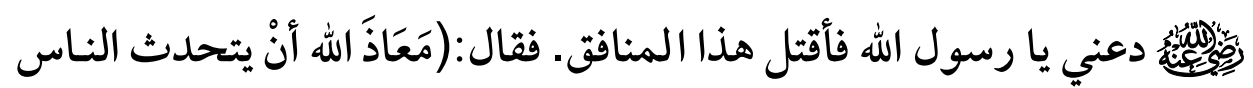

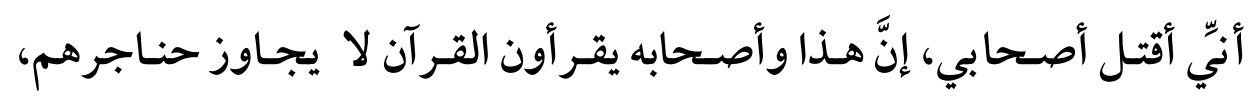

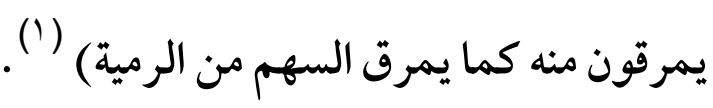
وجه الدلالة:

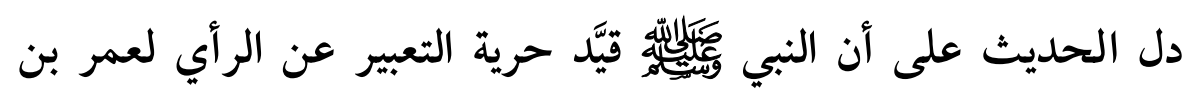

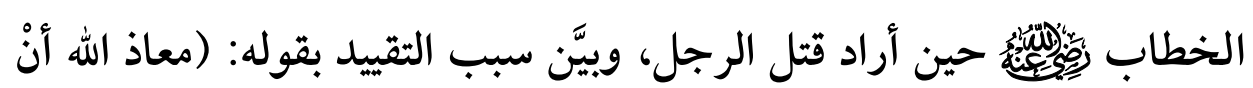
(1) أخرجه مسلم في صحيحه، كتاب الزكاة ، بـاب ذكر الخوارج وصفاتهم، رقم 
(79६) سلطة ولي الأمر في تقييد العريات السياسية للمصلحة العامة

يتحدث الناس أنبّ أقتل أصحابي) لأن في قتله مفسدةٌ عظيمةٌ، فتمت

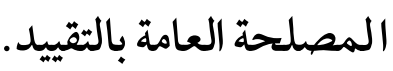

وروي أنّ أنسس بـن مالك قـال: لمـا فتحـت مكـة قسم الغنـائم في قـريش،

فقالت الأنصار: إنَّ هذا لهو العجب، إن سيوفنا تقطر من دمائهم، وإن غنائمنـا

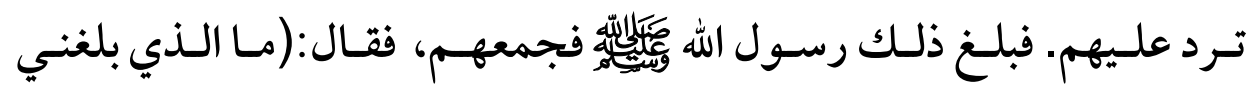
عنكم)قالوا: هو الذي بلغك،و كانوا لا يكذبون. قـال: (أمـا ترضسون أن يرجـع الناس بالدنيا إلى بيو تهم، وترجعون برسول الله إلى بيوتكم، لو سـلك الناس

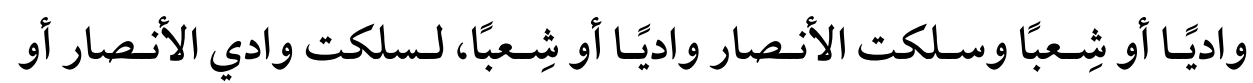

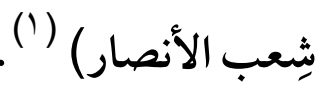

وجه الدلالة:

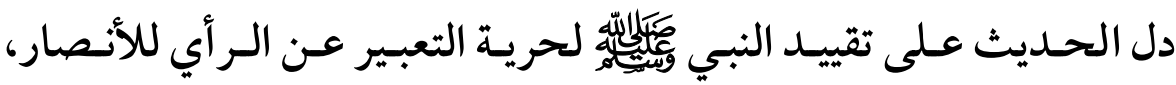

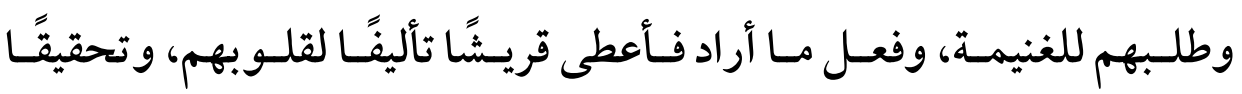

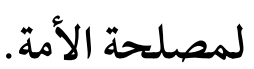

(1) متفق عليه ، أخرجه البخـاري في صحيحه، كتاب مناقب الأنصار، بـاب مناقـب الصحابة، رقـم (rVVN)، ومسسلم في صحيحه، كتـاب الزكاة، بـاب إعطاء المؤلفـة قلوبهم على الإسلام وتصبّر من قوي إيمانه، رقم (9 ه ـ (1). 


\section{الخاتمة}

تـم بفضل الله وتوفيقه الانتهاء مـن هـذا البحـث، الموسوم (سـلطة ولي الأمر في تقييد الحريـات السياسية للمصلحة العامـة) ، وهـذه بعض النتائج والتوصيات:

أولاً : النتائج:

1 - المباح هو: ما استوى فيه جانب الفعل والترك، فلا ثواب في فعله

$$
\text { ولا عقاب على تر كه. }
$$

ץ- التفقّه في المباح أمرٌ لا مفرَّ منه ؛ حتى يتحقق التكامل والتوازن بين أفراد

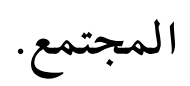

r- تقييد وليّ الأمر للمباح يـدخل ضـمن السياسة الشرعية، التي يـراد منها

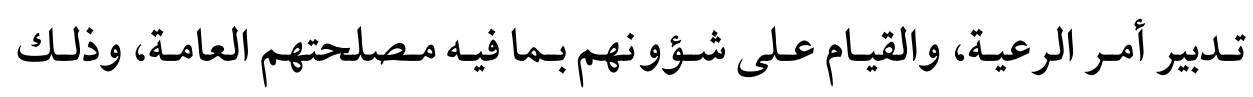

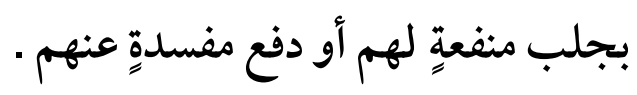

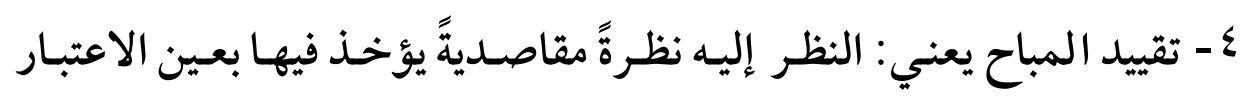
مـآلات الفعـل، والمـصالح المرجـوة منـه، أو المفاسـد المترتبـة على الإقـدام عليه. هـ الحريات السياسية جزء أصيل من صميم هـذا الدين، و ليست منحةًّ مـن أحدِ، إذ أنها تقوم على أساس أن الأمة هي صاحبة السيادة في شؤون الحكم .

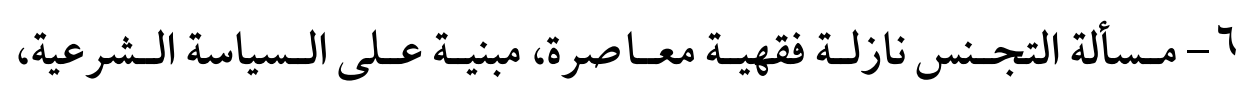
والاجتهاد الفقهي، تجري عليها الأحكام الخمسة. 
(797)

سلطة ولي الأمر في تقييد العريات السياسية للمصلحة العامة

V - تقوم الجنسية في الشريعة الإسـلامية على أسـاس الـدار، أو بتعبير آخر

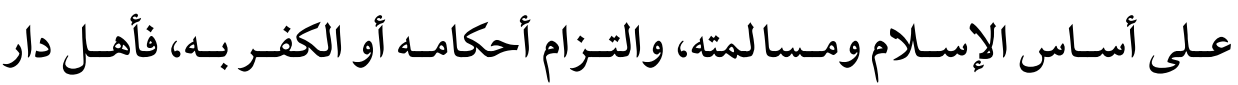
الإسلام لهم جنسية واحدة.

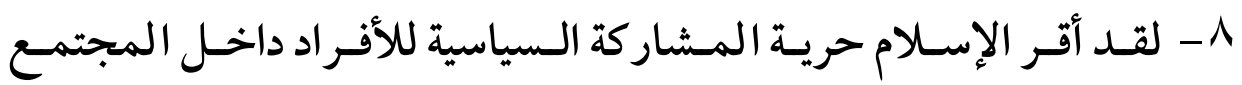
الإسلامي، ومن أهم صور هذه المشاركة: حق الترشـح، والانتخـاب، وتـولي

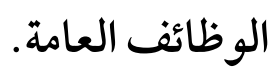

9 - حرية التعبير عن الرأي مطلب إنساني، وواجب إسلامي ، أرسـت قواعده

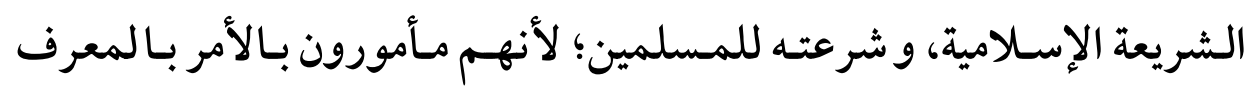

$$
\text { بمعروفٍ، والنهي عن المنكر بغير منكر. }
$$

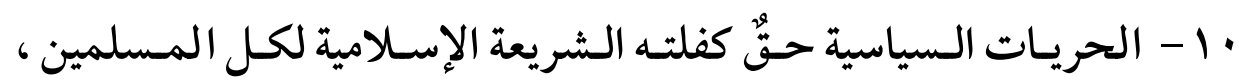

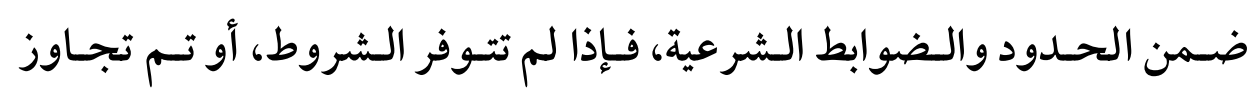
الضوابط ، أو ترتب عليها مفسدة محققة، جـاز لوليّ الأمر تقييدها؛ مر اعـاة للمصلحة العامة للمسلمين، لأن تصرفه في الرعية منوط بالمصلحة. ثانيًا: التوصيات : ا - على وليّ الأمر التزام العـدل والمـساواة بـين عمـوم الأمـة في الاستفادة من المباحات، واستغلال ثروات الأمة تحقيقًا للمصلحة العامة.

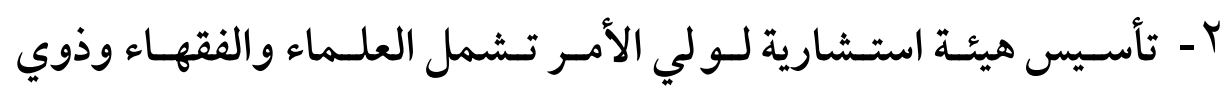
الخبرات ؛ للاستفادة منهم في النوازل الفقهية التي تطر أ على العباد والبلاد

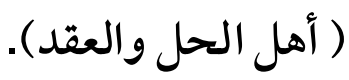


"ا - ينبغي على ولي الأمر تغليب المصلحة العامة على المصلحة الخاصـة، فلا مجاملة ولا محاباة لأحد على حساب المصلدة المعل العامة.

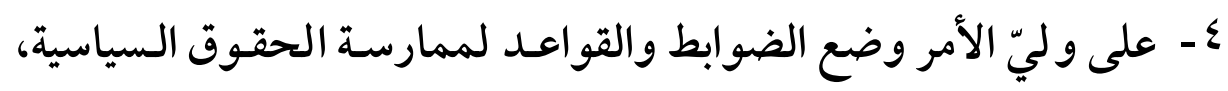
والسماح للشباب بممارسة حقوقهم السياسية وفق مـنهجٍ منضبطٍٍ، وآلياتٍ فاعلةٍ. 0- التأني في منح الجنسية أو إسقاطها حتى لا يهون الأمر ، وتسقط هيبة الأمة. 7 - فتح الباب أمام الجميع للترشح للمناصب القياديـة لكل مـ يـرى نفسه أهلاً لها، دون تعسف مع أحد ، أو محاباة لأحد. V التعبير عن الر أي في زعزعة الأمة، وحل عقدها، والنيل من استقر ارها.

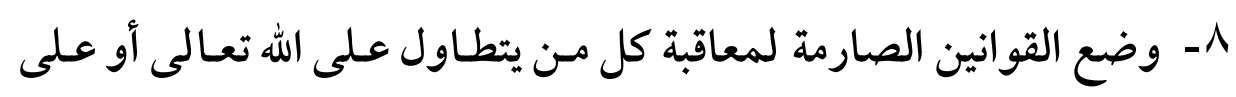
دينه أو على رسله بدعوى حرية الفكر والتعبير.

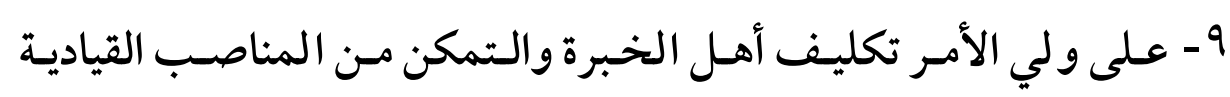

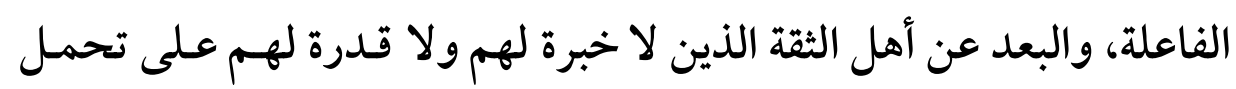

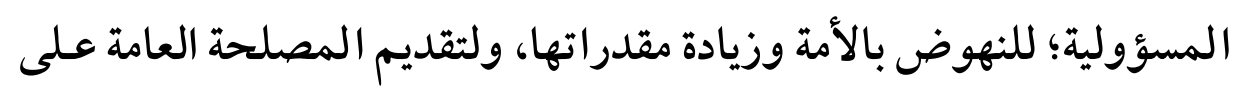
المصلحة الخاصة. • ل - تدريب الشباب تدريبًا سـليمًا على كيفيـة ممارسة الحريـات السياسية بعيدًا عن التعنت والقهر أو المغالاة والفوضى. ترئ. وآخر دعوانا أن الحمد اللّه رب العالمين 
$(79 \Lambda)$

\section{ثبت المصادر والمراجع}

1 أحكام القـر آن لأبي بكـر بـن العــبي محمـد بـن عبـد الله الأندلسي ، ط دار

الكتب العلمية، بيروت، الثالثة، ب +. r م.

Y-إرشاد الفحول إلي تحقيق الحـق مـن علـم الأصسول لمحمـد بـن علي بـن

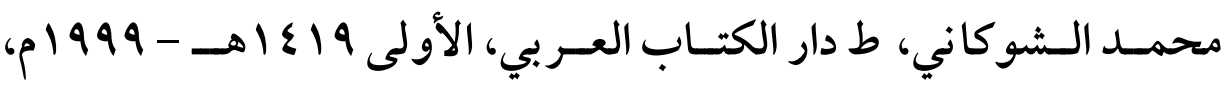
تحقيق الشيخ أحمد عزو عناية .

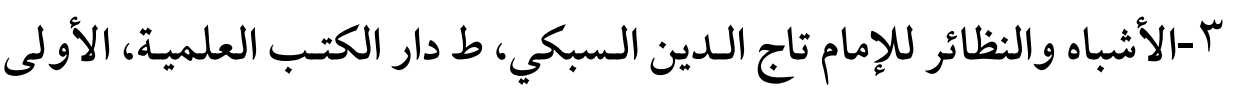
p $1991-ه 1 \leqslant 11$

ـ -الأشباه والنظائر للسيوطي، ط دار الكتب العلمية-بيروت، ب • ع أهـ.

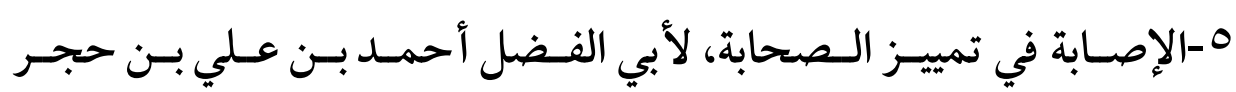
العسقلاني الشافعي ،ط دار الجيـل بـيروت، الأولى، Y I\& I هـ ، تحقيـق: علي محمد البجاوي. 7-إعلام الموقعين عن رب العالمين لأبي عبد الله محمد بـن أبي بكر أيوب الزرعي ، ط دار الجيل - بيروت سVY |م، تحقيق : طه عبد الرؤوف سعد. V الأم لأبي عبـد الله محمـد بـن إدريس الشافعي ، ط دار المعرفـة، بيروت، .

^-بحـوث في قضايا فقهيـة معـاصرة، للشيخ محمـد تقي عـثمان ، ط وزارة

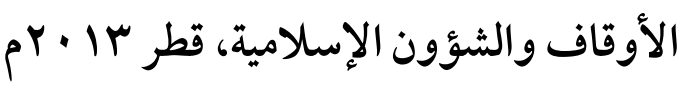


9-البداية والنهاية للحـافظ إسـماعيل بـن كثير ، ط دار إحياء التراث العربي

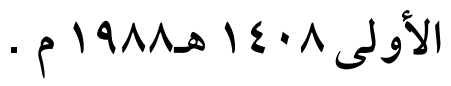
• ا -تاج العروس لمحمّد بن محمّد بن عبد الرزّاق الحسيني(الزَّبيدي) ، ط

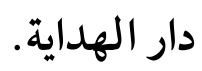

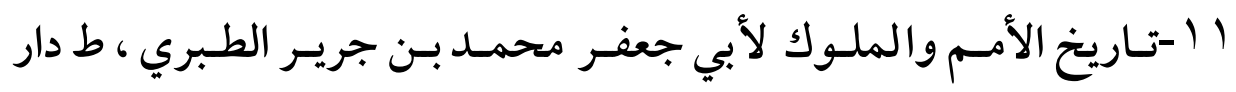
الكتب العلمية -بيروت ، الأولى V• ع أهـ. r ا -تاريخ الخلفاء لعبد الرحمن بن أبي بكر السيوطي ، ط مطبعة السعادة -

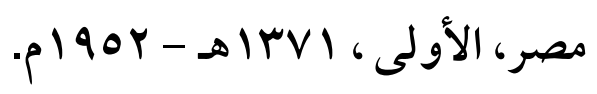
با ا -التاريخ الكبير لأبي عبدالهه محمد بن إسـماعيل البخـاري ، ط دار الفكر - بيروت ، تحقيق : السيد هاشم الندوي. ـ ا -تجــس المسسلم بجنـسية دولـة غـير إسـلامية، دعبـد الله بـن سـليمان

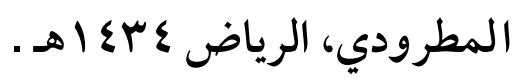
0 ا -التجنس، د عز الدين عبد الله مجلة العلوم القانونية والاقتصادية، جامعـة عين شمس ع 9 ام م.

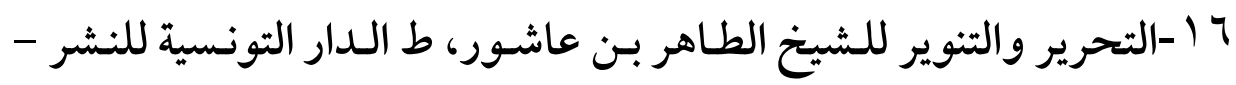

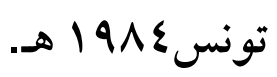




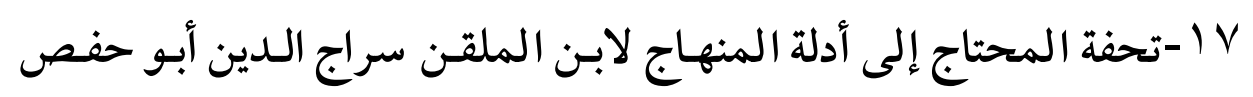

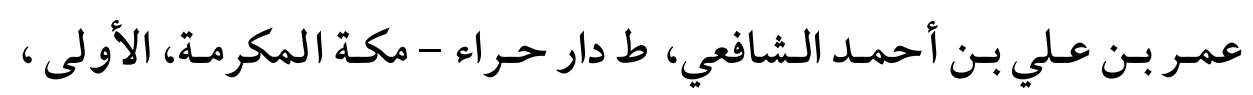
(1)

1 1 - تحفة المحتاج لابن حجر ، المكتبة التجارية الكبرى بمصر س 919 م. 9 ا -التشريع الجنائي الإسـلامي لعبد القـادر عـوده، ط دار الكتاب العـربي،

$$
\text { بيروت. }
$$

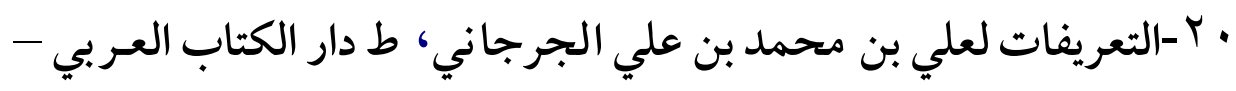

$$
\text { بيروت، الأولى ، } 0 \text { · ع } 1 \text { هـ تحقيق : إبراهيم الإبياري. }
$$

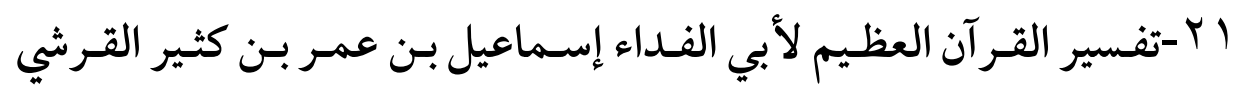
الدمشقي، ط دار طيبة للنشر والتوزيع، الثانية · rع اهـ - 1999 م، تحقيق : سامي بن محمد سلامة. Y Y -تقييد المبـاح، د الحسبين المسوس، مركـز نـماء للبحسوث والدراسـات،

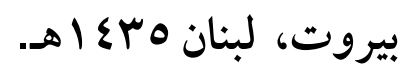
r ب تلخيص الحبير في تخريج أحاديـث الر افعي الكبير لأبي الفضل أحمـــ بن علي بن محمـد بـن أحمـد بـن حجر العسقلاني، ط دار الكتب العلمية ،

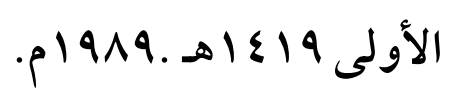

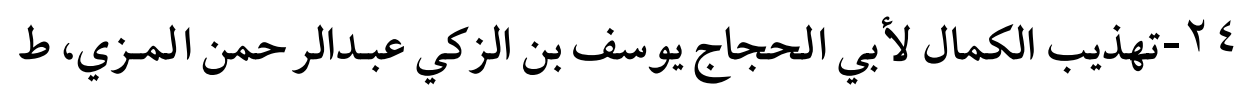

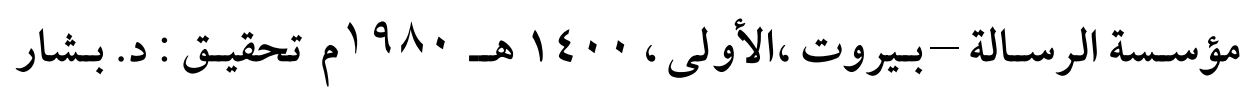


0Y-الثقات لأبي حساتم محمـد بـن حبـان بـن أحمـد التميمي البستي، ط دار

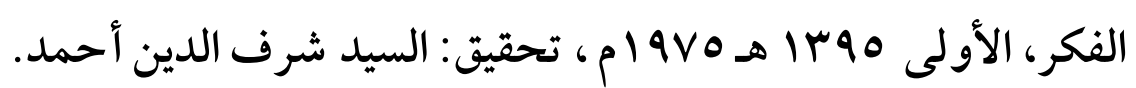

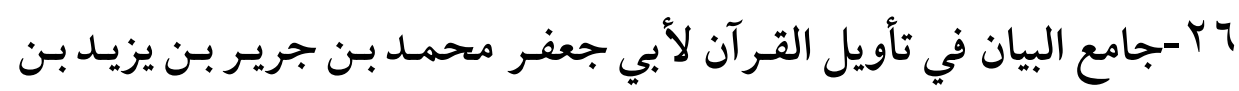

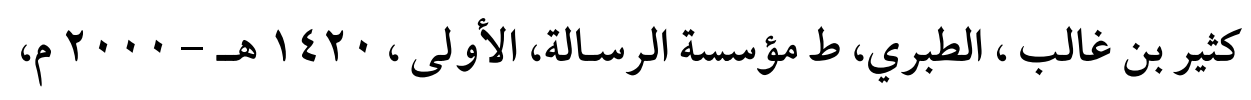
تحقيق : أحمد محمد شاكر.

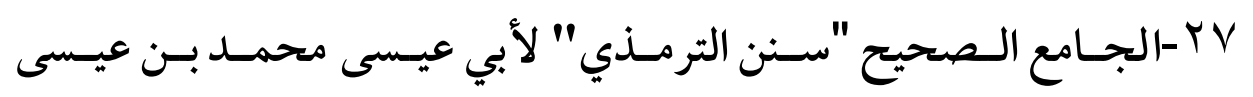

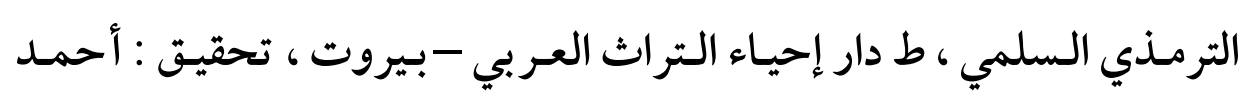
محمد شاكر وآخرون.

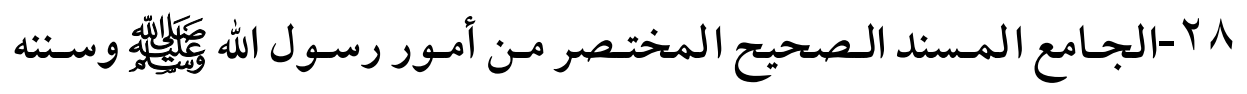
وأيامه (صحيح البخاري) لأبي عبدالله محمـد بـن إسماعيل البخـاري ،ط دار

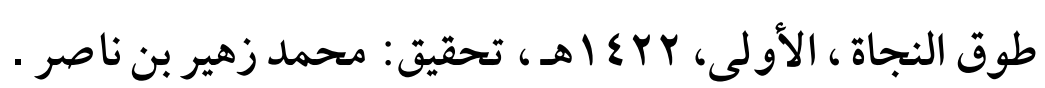
9 ؟ -الجريمة السياسية في الشريعة الإسلامية والقانون، منذر عرفات زيتون،

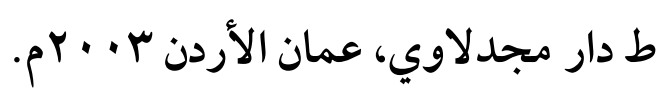
• ب-الجنسية في الـشريعة الإسـلامية، د رحيـل غرايسة، ط الـشبكة العربيـة

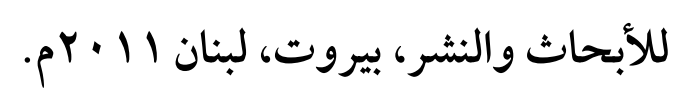

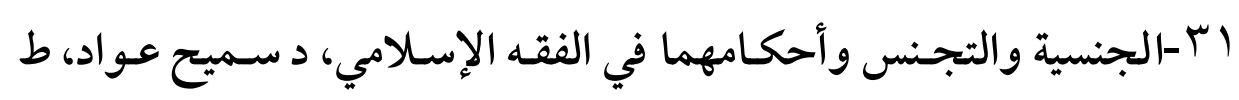

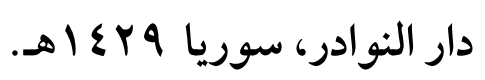




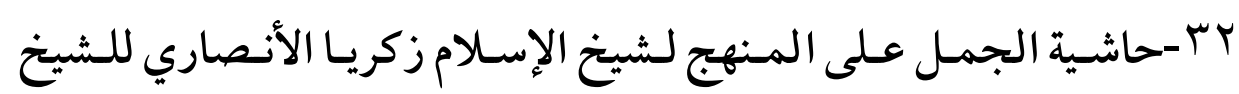
سليمان الجمل ، ط دار الفكر -بيروت.

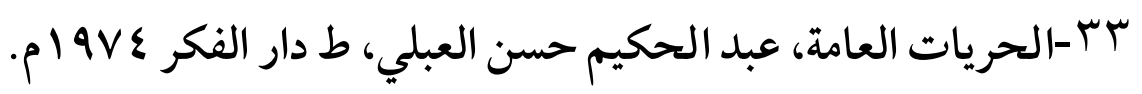
ع ז-حق التعبيــــر عن الر أي ، محمد بن عبداله الدخيل،

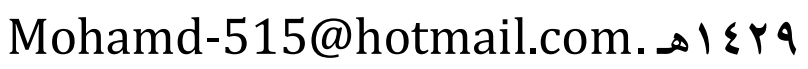

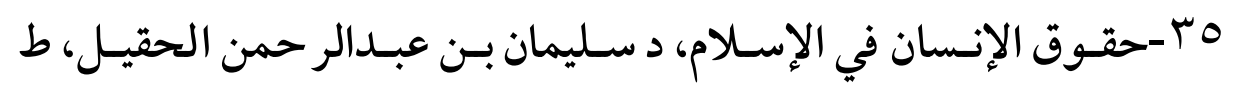

وكالة الفرزدق، الرياضع (1 اهـ \&99 ام.

جس-الحقوق السياسية والقانونية للمهاجرين ومزدوجي الجنسية لواء عـادل

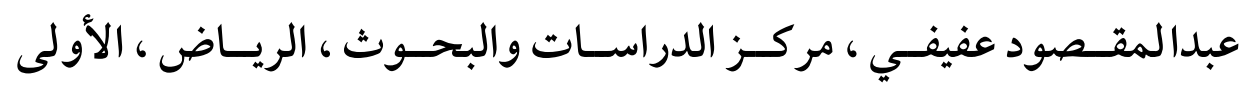

$$
\text { pr. }
$$

V V -الحقـوق والحريـات السياسية في الشريعة الإسـلامية، درحيل محمـــ

$$
\text { غرايبه، ط دار المنار، عمان الأردن ·... }
$$

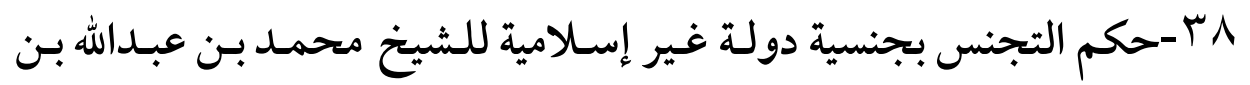

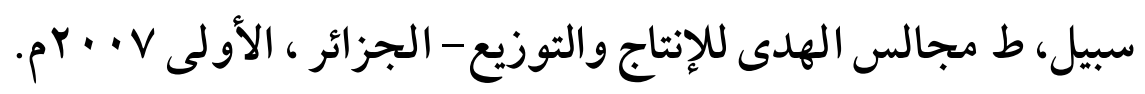
q ب-سلسلة الأحاديث الضعيفة والموضوعة لناصر الدين الألباني ،ط مكتبـة

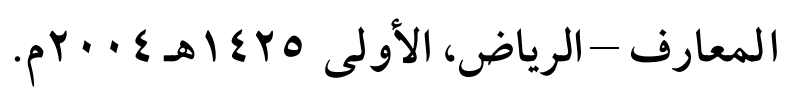

• ـ -سلطة ولي الأمر في تقييد سلطة القاضي د محمد بن عبداله المرزوقي،

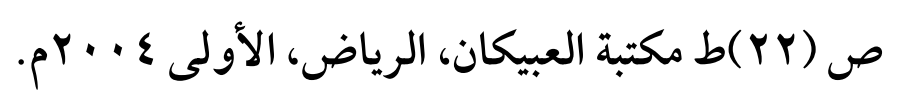




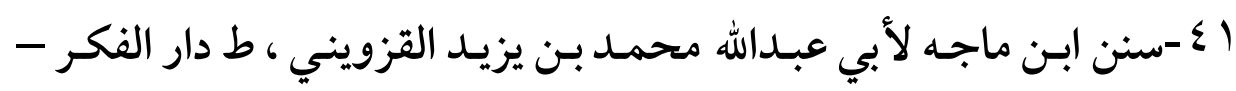
بيروت ، تحقيق : محمد فؤاد عبد الباقي. Y ك-ســن أبي داود لأبي داود سـليمان بـن الأشـعث السجـستاني ، ط دار

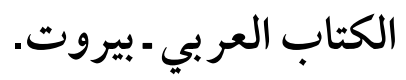
بـ -السنن الكبرى، لأبي عبـد الر حمن أحمـد بـن شعيب النسائي، ط دار

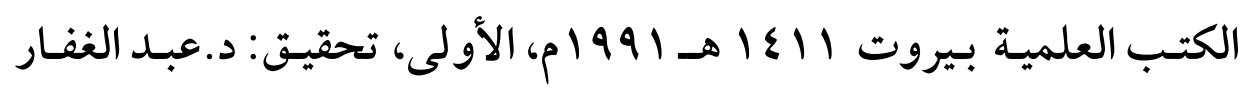
البنداري ، سيد كسروي حسن.

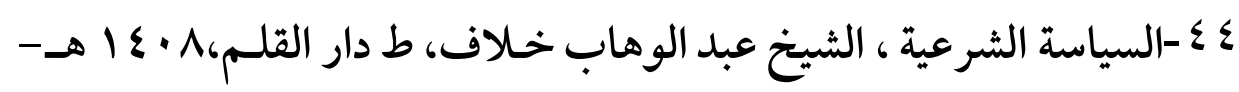
p p 911 0ـ - السيرة النبوية لابـن هشام ، ط دار الجيل ، بيروت || إ اهـ ، تحقيتق: طه عبد الرءوف سعد. 7 1 - شرح الكوكب المنير لتقي الـدين أبـو البقـاء محمـد بـن أحمـد بـن عبـد

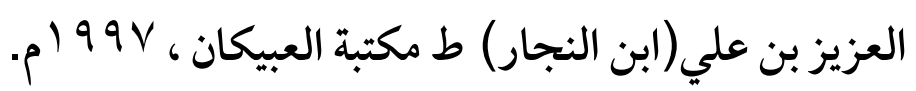

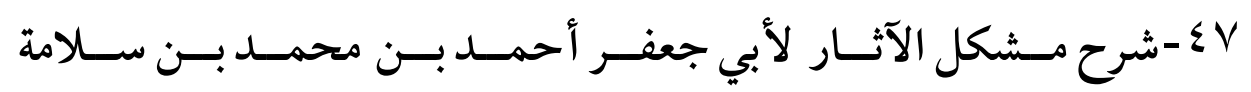

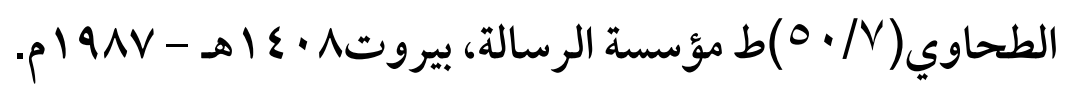
^§ -صحيح ابن حبـان ، أبو حـاتم محمـد بـن حبـان بـن أحمـد التميمي

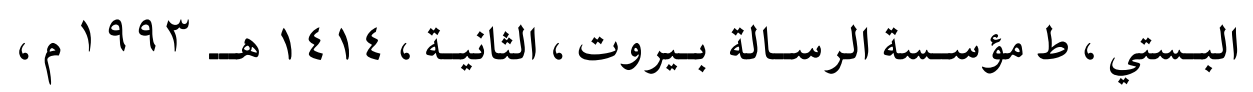
تحقيق : شعيب الأرنؤوط. 


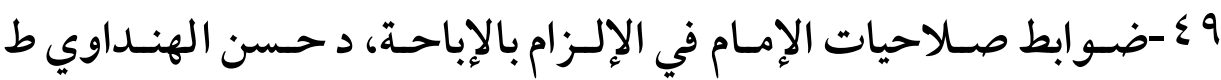

مجلة العدل ، العدد77، هـ؟ اهـ.

• 0-عارضة الأحوزي بشرح صحيح الترمذي لأبي بكر بـن العربي المـالكي ، ك ، دار الكتب العلمية بيروت. 1 إ-علم أصول الفقه للشيخ عبدالوهاب خلاف، ط مكتبة الدعوة الإسلامية

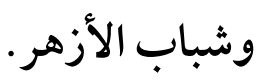

ror-فتح الباري شرح صحيح البخاري لأبي الفضل أحمد بن علي بن حجر

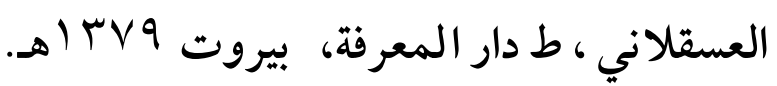
ror-الفقيه و المتفقه لأبي بكر أحمد بن علي بـن ثابـت بـن أحمـد الخطيبـ البغدادي ، ط دار ابن الجوزي السعودية، الثانية، إ؟ـ اهـ ، تحقيق عـادل بـن يوسف الغرازي. ؟ 0-فيض الخاطر لأحمد أمين، ط دار المحراب الأدبي للنشر والتوزيع. 00-القانون الدولي الخاص ، د أحمد عشوش، حقوق بنها r I ا ب م.

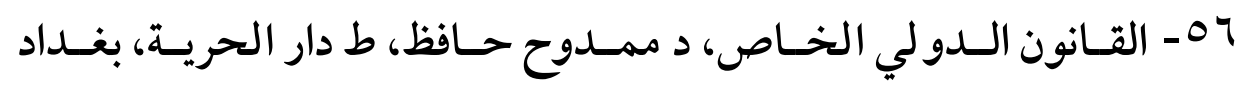
p 19VV لV القانون الدولي الخـاص، دهشام علي صـادق، ط دار الفكر الجـامعي،

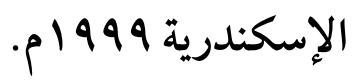


101قــرارات وتوصسيات مجمـع الفقـه الإسـلامي الـدولي، منظمـة المؤتمر

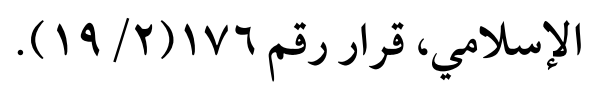

99 هـلسان العـبـ، محمـد بـن مكـرم بـن منظور الأفريقي المصري، ط دار

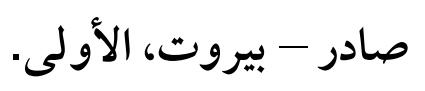

• 7 - مجلة المجمع الفقهي الإسلامي، السنة الثانية، العدد الرابع.

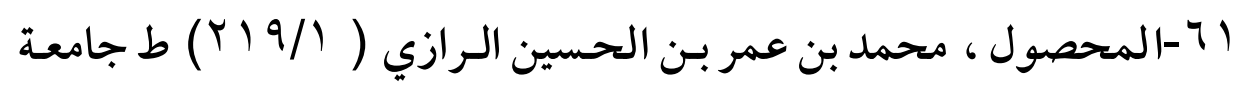

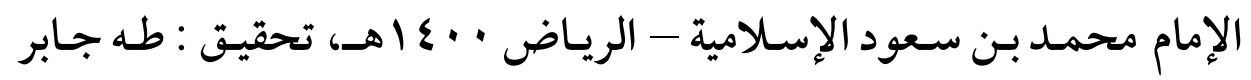
فياض العلواني. بT-المحلى بالآثار لأبي محمـد علي بـن أحمـد بـن حزم الأندلسي ، ط دار

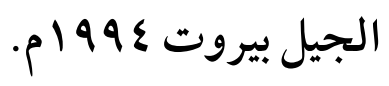
با 4 - مختـار الصحاح، محمـد بـن أبي بكـر بـن عبـدالقادر الرازي، ط مكتبـة لبنان ناشرون - بيروت إع 1 1990 هـ 199 م. ـ 7-المـستدرك عـلى الصحيحين لأبي عبـداله محمــد بـن عبـداله الحـاكم

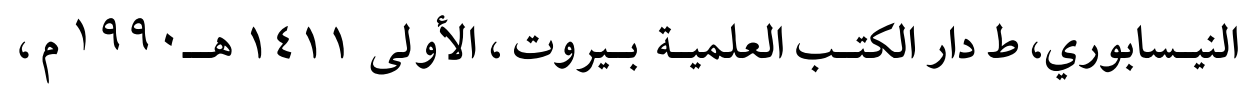
تحقيق : مصطفى عبد القادر عطا.

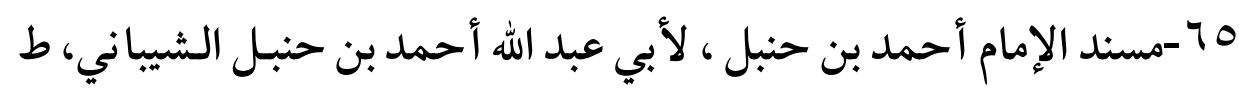
مؤسسة قرطبة - القاهرة.

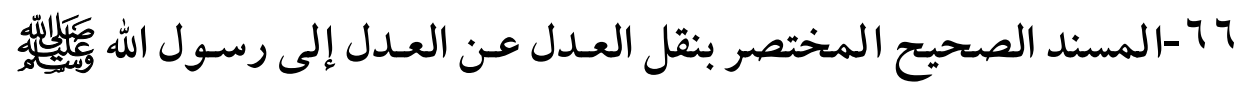


$(V \cdot y)$

سلطة ولي الأمر في تقييد العريات السياسية للمصلحة العامة

لأبي الحسن مسلم بـن الحجاج القشيري النيسابوري (المتوفى: الجrهـ)،

ط دار إحياء التراث العربي -بيروت ، تحقيق: محمد فؤاد عبد الباقي. VT V-المـشاركات الـسياسية المعـاصرة ، د محمــد يـسري إبـر اهيم، ط دار

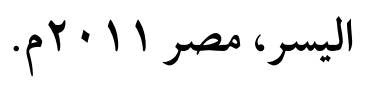

17-المشار كة السياسية والديمقر اطية، د سامية خضر صالح، كلية التربية ،

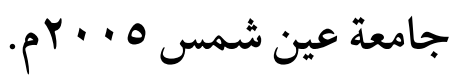

99 7-مشاهير علـماء الأمصار لابـن حبـان ، ذكر المشاهير أتبـاع التابعين

$$
\text { باليمن ، ط دار الكتب العلمية - بيروت } 909 \text { (م . }
$$

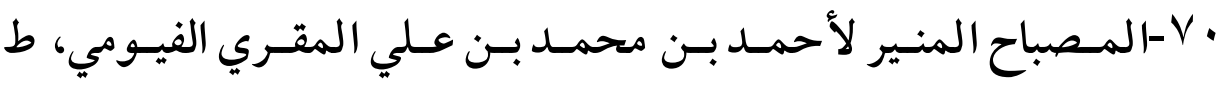

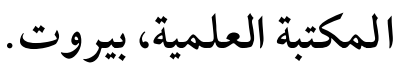

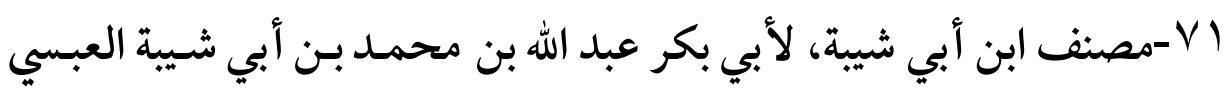

$$
\text { الكوفي، ط دار القبلة، تحقيق : محمد عوامة. }
$$

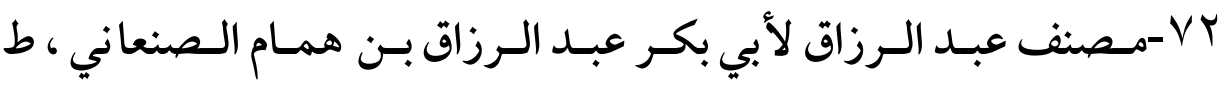
المكتب الإسلامي -بيروت ، الثانية ، ب +ـ ا هـ ، تحقيق : حبيـب الرحمن

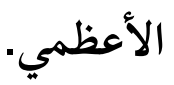

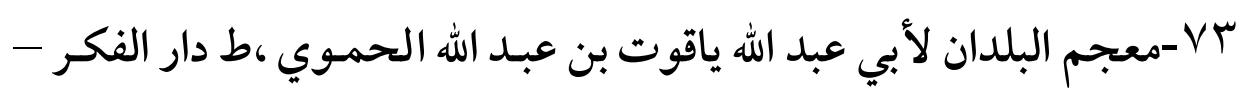

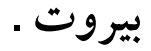
ع V-المعجم الكبير، ط مجمع اللغة العربية، بمصر. 
0 - المعجم الوسيط، إبر اهيم مصطفى وأحمـد الزيـات وحامـد عبد القـادر و محمد النجار ط دار الدعوة، تحقيق مجمع اللغة العربية.

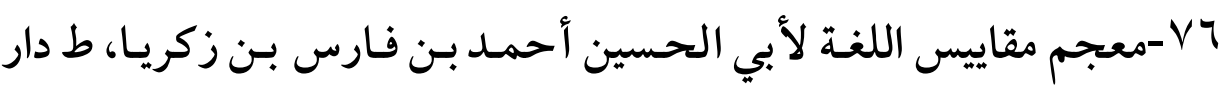

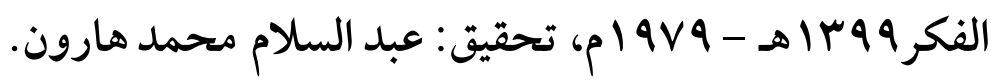
مقاصد الشريعة الإسلامية للشيخ الطاهر بـن عاشور، ط وزارة الأوقـاف -VV

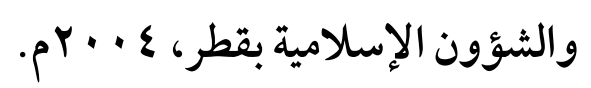
المنهاج شرح صحيح مسلم بـن الحجاج لأبي زكريا يحيى بن شرف -VA بن مري النووي، ط دار إحياء التراث العربي -بيروت، الثانية ، Y ب ا هـ. V9 الموافقـات، إبـر اهيم بـن موسى بـن محمـد اللخمي الغرنـاطي الشهير

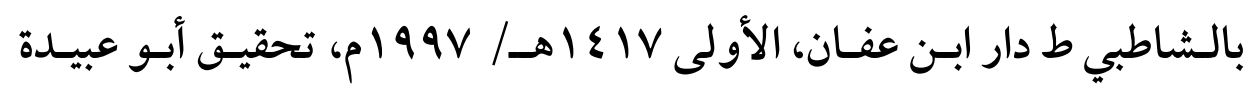
مشهور بن حسن آل سلمان.

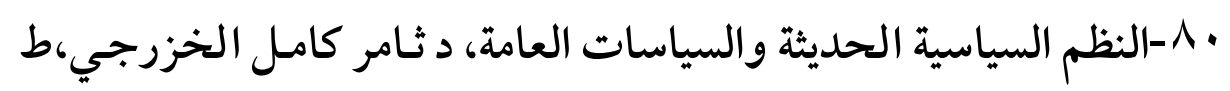

$$
\text { دار مجدلاوي، عمان ؟ + - ب م. }
$$

1-1النهاية في غريب الحـديث والأثر، لأبي السعادات المبارك بـن محمـد الجـزري، ط المكتبـة العلميـة ، بـيروت 99 19 اهـ 9V9 ام تحقيـق: طـاهر الزاوى و محمود الطناحي · r Y r-نور الصباح في فقه تقييد المباح، أحمد خالد الطحان، شبكة الألوكة. 
$(V \cdot \Lambda)$

سلطة ولي الأمر في تقييد الحريات السياسية للمصلحة العامة

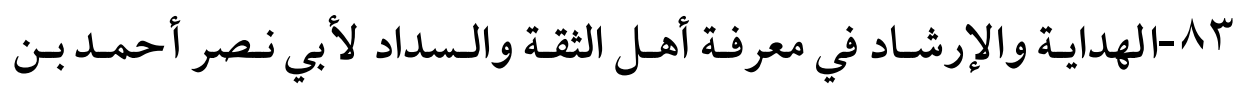

محمد بن الحسين بـن الحسن، البخـاري الكلابـاذي ، ط دار ع ^-المعرفة -

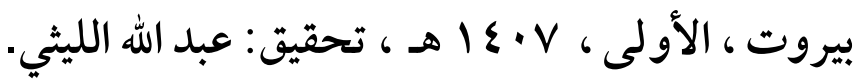

1-الـوجيز في القـانون الــولي الخـاص ، د ريـاض فـؤاد عبـد المـنعم و د

سامية راشد ، ط دار النهضة العربية ، القاهرة 979 ام.

14-الوجيز في القانون الدولي الخاص، دصوفي أبو طالب، ط دار النهضة

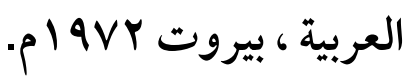


$(v \cdot 9)$

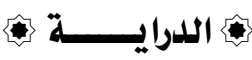

فهرس المرضوعات

\begin{tabular}{|c|c|c|}
\hline رقم الصفحة & الموضوع & p \\
\hline rir & 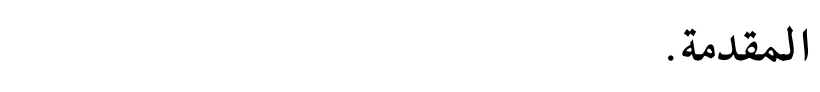 & 1 \\
\hline 710 & خطة البحث. & r \\
\hline $71 \mathrm{~V}$ & التمهيد. & r \\
\hline Tro & الفصل الأول: سلطة ولي الأمر في تقييد المباح. & $\varepsilon$ \\
\hline TYT & المبحث الأول: حقيقة تقييد المباح. & 0 \\
\hline Tr & المبحث الثاني: ضوابط تقييد المباح. & 7 \\
\hline $7 \leqslant 7$ & المبحث الثالث: نماذج لتقييد المباح بضو ابطه. & V \\
\hline 701 & الفصل الثاني: تقييد الحريات السياسية. & $\wedge$ \\
\hline 7or & المبحث الأول : تقييد حرية التجنس. & 9 \\
\hline TV $\varepsilon$ & المبحث الثاني: تقييد حرية المشاركة السياسية. & 1. \\
\hline 710 & المبحث الثالث: تقييد حرية التعبير عن الر أي. & 11 \\
\hline 790 & 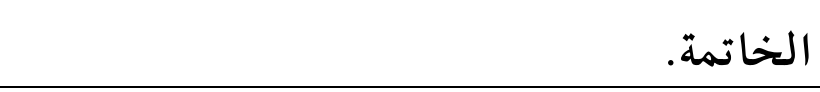 & ir \\
\hline 791 & فهرس المصادر والمراجع. & ir \\
\hline$v \cdot q$ & فهرس الموضوعات. & $1 \varepsilon$ \\
\hline
\end{tabular}

